\title{
Adopting Inflation Targeting: Practical Issues for Emerging Market Countries
}

Andrea Schaechter, Mark R. Stone, and Mark Zelmer

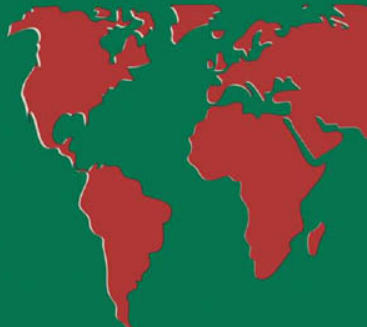




\section{Adopting Inflation Targeting: Practical Issues for Emerging Market Countries}

Andrea Schaechter, Mark R. Stone, and Mark Zelmer 


\section{(C) 2000 International Monetary Fund \\ Production: IMF Graphics Section \\ Figures: Theodore F. Peters, Jr. \\ Typesetting: Alicia Etchebarne-Bourdin}

\section{Cataloging-in-Publication Data}

Adopting inflation targeting: practical issues for emerging market countries/Andrea Schaechter, Mark R. Stone, and Mark Zelmer.

p. cm.-(Occasional paper; no. 202)

Includes bibliographical references.

ISBN 1-55775-991-X

1. Anti-inflationary policies. 2. Monetary policy. 3. Post-communismEconomic aspects. I. Stone, Mark R. (Mark Richard). II. Zelmer, Mark. III. Title. IV. Occasional paper (International Monetary Fund); no. 202.

HG229.\$3122 2000

339.5'3'091724-dc21

$00-053562$

Price: US $\$ 20.00$

(US\$17.50 to full-time faculty members and students at universities and colleges)

Please send orders to:

International Monetary Fund, Publication Services 700 19th Street, N.W., Washington, D.C. 20431, U.S.A.

Tel.: (202) 623-7430 Telefax: (202) 623-7201

E-mail: publications@imf.org

Internet: http://www.imf.org

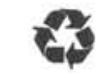

recycled paper 


\section{Contents}

\begin{tabular}{|c|c|c|}
\hline \multicolumn{2}{|c|}{ Preface } & \multirow[t]{2}{*}{ vii } \\
\hline I & Executive Summary & \\
\hline II & Introduction & 4 \\
\hline \multirow[t]{4}{*}{ III } & Institutional Framework & 6 \\
\hline & Central Bank Legal Framework & 6 \\
\hline & Inflation Target Design & 7 \\
\hline & Accountability and Transparency & 11 \\
\hline \multirow[t]{6}{*}{ IV } & Transition Issues & 15 \\
\hline & Inflation Trends & 15 \\
\hline & Disinflation Experiences & 16 \\
\hline & Shifting from an Exchange Rate Regime & 17 \\
\hline & Balancing Risks & 18 \\
\hline & Long-Run Inflation Objective & 19 \\
\hline \multirow[t]{8}{*}{$\mathbf{v}$} & Operational Issues & 21 \\
\hline & Inflation Forecasting & 21 \\
\hline & Policy Transmission Channels & 22 \\
\hline & Policy Implementation & 23 \\
\hline & Inflation Targeting and IMF Conditionality & 25 \\
\hline & Changing Economic Relationships & 26 \\
\hline & Breaches of the Inflation Target & 26 \\
\hline & Responding to Significant Economic and Financial Shocks & 30 \\
\hline \multirow[t]{4}{*}{ VI } & Organizational Implications for Central Banks & 33 \\
\hline & Internal Decision Making & 33 \\
\hline & Monetary Policy Committees & 34 \\
\hline & Internal Resource Requirements & 34 \\
\hline VII & Conclusion & 37 \\
\hline \multicolumn{3}{|c|}{ Appendices } \\
\hline & $\begin{array}{l}\text { Economic Structure of Emerging Market Inflation } \\
\text { Targeters }\end{array}$ & 39 \\
\hline & II Institutional Aspects of Inflation Targeting & 43 \\
\hline & III Country Studies & 46 \\
\hline
\end{tabular}


Figures

1.1. Inflation Rate at Adoption of Inflation Targeting 1

5.1. Industrial Countries: Annual Inflation Rates and Inflation Targets

5.2. Emerging Market Countries: Annual Inflation Rates and Inflation Targets

Tables

1.1. Synopsis of Inflation Targeting Frameworks

3.1. Central Bank Legal Frameworks

3.2. Announcement of Inflation Targets

3.3. Target Horizon

3.4. Price Indices

3.5. Point Target or Target Range

3.6. Evolution of Inflation Targets

$\frac{3.7 . \text { Communication Vehicles Employed by Inflation Targeters }}{\text { 4.1. Timing of Transitions to Full-Fledged Inflation Targeting }}$ by Emerging Market Countries

4.2. Inflation During Transition to Full-Fledged Inflation Targeting

4.3. Inflation Prior to Beginning of Transition to Inflation Targeting

4.4. Exchange Rate Regime Prior to Adoption of Inflation Targeting

4.5. Motivations for Adopting Inflation Targeting

5.1. Important Features of Monetary Policy Transmission Channels

5.2. Operating Targets and Main Instruments of Monetary Policy

5.3. Quarterly Breaches of Inflation Targets

27

5.4. The Policy Response of Inflation Targeters to the Asian/Russian Crises

6.1. Monetary Policy Decision-Making Body

6.2. Role of Non-Central Bank Members

6.3. Votes versus Consensus Decisions

6.4. Frequency of Monetary Policy Meetings

6.5. Timing of Policy Actions

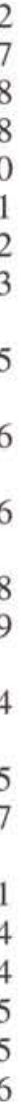

\section{Appendix Tables}

A1.1. Emerging Market Countries Ranked by GDP and GDP Per Capita, 1998

A1.2. Emerging Market Countries: Inflation Targeting and

Comparator Countries

A1.3. Key Financial Ratios for Inflation Targeters

41

A1.4. Industrial and Emerging Market Countries: Currency

Crises and Crashes, 1975-97

A2.1. Institutional Aspects of Inflation Targeting in Emerging Market Countries

A2.2. Institutional Aspects of Inflation Targeting in Industrial Countries 
The following symbols have been used throughout this paper:

... to indicate that data are not available;

- to indicate that the figure is zero or less than half the final digit shown, or that the item does not exist;

- between years or months (e.g., 1998-99 or January-June) to indicate the years or months covered, including the beginning and ending years or months;

I between years (e.g., 1998/99) to indicate a fiscal (financial) year.

"Billion" means a thousand million.

Minor discrepancies between constituent figures and totals are due to rounding.

The term "country," as used in this paper, does not in all cases refer to a territorial entity that is a state as understood by international law and practice; the term also covers some territorial entities that are not states, but for which statistical data are maintained and provided internationally on a separate and independent basis. 
This page intentionally left blank

CInternational Monetary Fund. Not for Redistribution 


\section{Preface}

Inflation targeting is gaining in popularity among emerging market countries. This has led to an increased demand for technical assistance from the IMF to help these countries meet the practical challenges that they face in adopting this policy regime. This paper summarizes the lessons that can be drawn for emerging market countries on the operational and institutional policy challenges posed by inflation targeting. It is based on industrial countries' experiences with inflation targeting as well as the relatively short experience of emerging market countries. The lessons drawn here can be expected to be refined as the range of country experience with inflation targeting widens.

The material in this paper was originally prepared for the information of the IMF's Executive Board in August 2000. The authors are most grateful for the detailed comments and discussions with officials in a number of inflation targeting central banks, notably Kevin Clinton (Bank of Canada), Guy Debelle (Reserve Bank of Australia), Akiva Offenbacher (Bank of Israel), Michael Reddell (Reserve Bank of New Zealand), Klaus Schmidt-Hebbel (Banco Central de Chile), and Roger Clews and Gabriel Sterne (Bank of England). For guidance throughout the preparation of the paper, the authors are especially indebted to Stefan Ingves, Director of the IMF's Monetary and Exchange Affairs (MAE) Department, Tomás J.T. Baliño, V. Sundararajan, and Piero Ugolini. The paper has also benefited from comments of Stanley Fischer, First Deputy Managing Director of the IMF, and many colleagues in MAE and other departments in the IMF. The authors would particularly like to thank Warren Coats, Claudia Dziobek, Haizhou Huang, Alain Ize, R. Barry Johnston, Meral Karasulu, John E. Leimone, Alfredo Leone, R. Armando Morales, and Mark Swinburne-all of MAE. The authors are grateful for the excellent cooperation with colleagues in other departments of the IMF and would like to acknowledge the contributions they have received, in particular from Anupam Basu, Gunnar Jonsson, and Arto Kovanen (African Department); Scott Roger (Asia and Pacific Department); Masahiko Takeda (European I Department); David Owen and Odd Per Brekk (European II Department); Adrienne Cheasty and Istvan P. Székely (Fiscal Affairs Department); Enzo Croce and Evan Tanner (IMF Institute); Timothy Lane (Policy Development and Review Department); Peter Isard, Eswar S. Prasad and Miguel Savastano (Research Department); David Goldsbrough, Francisco de Asis Nadal-De Simone, and Gerd J. Schwartz (Western Hemisphere Department).

The authors are also indebted to Patricia Mendoza and Leny Nikolov for excellent secretarial assistance in numerous drafts, Kiran Sastry for research assistance, and Natalie Baumer for editorial assistance. Jacqueline Irving of the External Relations Department edited the manuscript and coordinated the production of the publication. The views expressed in the paper, as well as any errors, are the sole responsibility of the authors and do not necessarily reflect the views of the national authorities or the IMF Executive Directors. 
This page intentionally left blank

CInternational Monetary Fund. Not for Redistribution 


\section{Executive Summary}

$\mathrm{n}$ recent years, emerging market countries have joined industrial countries in adopting monetary policy frameworks of formal inflation targeting. Motivated by increased demand by emerging market countries for IMF technical assistance on inflation targeting, this paper examines the institutional and operational practicalities of inflation targeting for emerging market countries adopting this regime. The paper spells out the trade-offs raised in the formulation of an inflation targeting framework and describes the approaches to these trade-offs used by inflation targeting countries.

This paper is founded on the body of knowledge formed by the years of industrial country experience with inflation targeting, as well as the more recent formulation of inflation targeting frameworks by emerging market countries. The countries identified here as practitioners of inflation targeting are those considered to have adopted most of the elements of a fullfledged inflation targeting framework (Figure 1.1).
The experience of these countries suggests that the foundations for successful, full-fledged inflation targeting are built on the following: a strong fiscal position and entrenched macroeconomic stability; a welldeveloped financial system; central bank instrument independence and a mandate to achieve price stability; a reasonably well understood transmission mechanism between monetary policy actions and inflation; a sound methodology for constructing inflation forecasts; and transparency of monetary policy to build accountability and credibility. Many of these elements, especially a strong fiscal position, are needed for sound monetary policy regardless of the policy objective. In addition, these elements do not need to be in place before a country begins the transition toward full-fledged inflation targeting.

The inherent differences reported in this paper between the six emerging market inflation targeting countries-Brazil, Chile, the Czech Republic, Israel, Poland, and South Africa-and other emerging market countries may shed some light on the preferred

\section{Figure I.I. Inflation Rate at Adoption of Inflation Targeting}

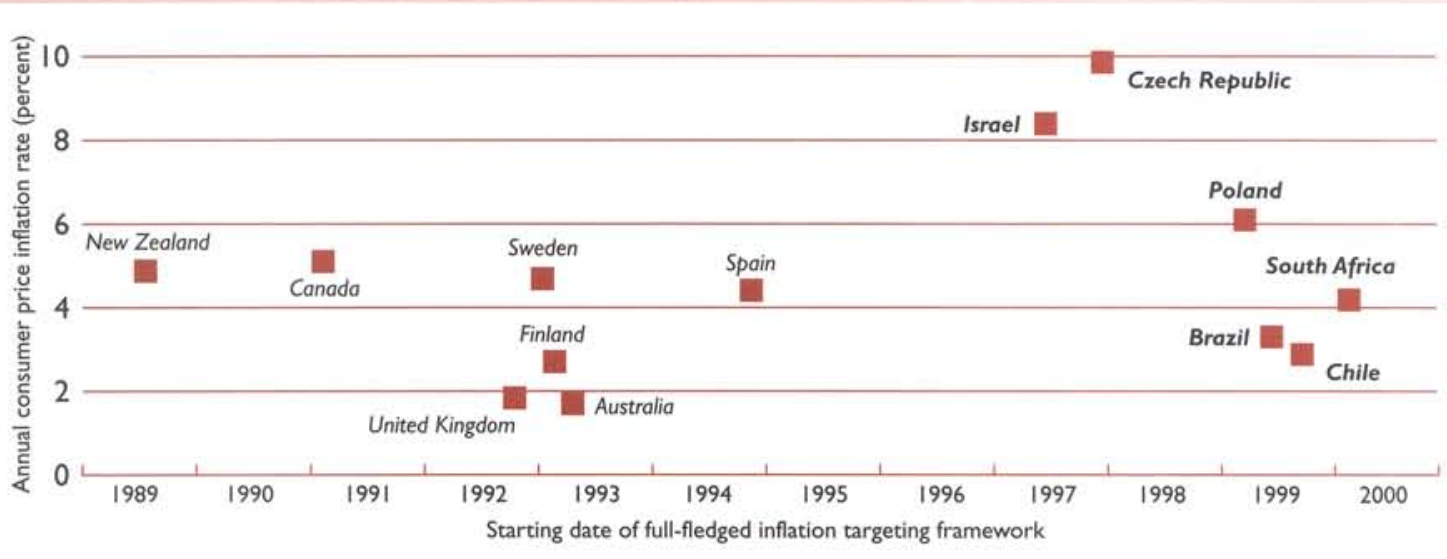

Sources: Central bank websites and reports; Bernanke and others (1999); IMF, International Financial Statistics. See Table 4.I of this report. Note: Emerging market countries are in bold. 
Table I.I.Synopsis of Inflation Targeting Frameworks

Institutional Framework

Central bank legal framework

Design of the inflation target Announcement of target

Target horizon

Price index

Formal escape clauses

Point target or target range

Accountability and transparency

Instrument independence and currency or price stability is a central bank objective in all cases. Central bank financing of government deficit is limited or prohibited in all emerging market countries.

Announced by government or jointly by government and central bank, unless the central bank has an explicit mandate for price stability as the primary objective. Indefinite for countries at longer-run inflation rate and annual for countries in disinflation.

Consumer price index for most emerging market countries and core inflation for most industrial countries.

Only used by several countries.

Target range preferred by most countries given uncertainties associated with hitting targets. Point targets have been adopted in some cases to focus inflation expectations.

Press releases of policy changes, regular inflation outlook reports, active dialogue with the private sector, and in some cases, publication of inflation forecasting models.

Operational Issues: Conduct of Monetary Policy

Inflation forecasting

Policy transmission channels

Policy implementation

Changing economic relationships

Responding to economic and financial shocks

Breaches of the inflation target

Internal decision making
Monetary policy committees
Central bank organization

\section{Disinflation}

Long-run inflation objective

Shifting from a fixed exchange rate regime
Based on indicator variables, quantitative economic models, discussions with market participants, and, especially for emerging market countries, qualitative judgment.

Emerging market countries with higher rates of inflation have channels characterized by downward price stickiness and rapid exchange rate pass-through.

All countries use market-based instruments to target a short-term interest rate. Changes in official interest rates reflect deviations of inflation from the target and the output gap.

As inflation targeting framework gains credibility, linkages between inflation and the level of economic activity seem to weaken.

Responses to external shocks range from doing nothing to a mixture of foreign exchange intervention and tighter monetary policy, depending on whether shocks are expected to affect inflation expectations or the stability of the financial system.

Asymmetric responses to breaches of floor and ceiling during disinflation, and symmetric responses when inflation is at the long-run level; breaches do not seem to have damaged credibility.

Organizational Implications for Central Banks

Many central banks have incorporated a broader range of perspectives and decentralized their organizational structure to enhance judgment-based decision making.

Most central banks have formal committees. Consensus decisions are typically published while voting records are not.

Emerging market central banks have reorganized to improve data collection, inflation forecasting, and policy analysis.

Transition Issues

Emerging market countries that started with higher inflation and crawling exchange rate bands disinflated over a long period to minimize output disruptions.

Consensus of around $1-3$ percent for industrial countries and somewhat higher for emerging market countries.

Slow and fast-track transitions from an exchange rate regime to full-fledged inflation targeting framework for emerging market countries. 
starting point and conditions for inflation targeting. The inflation targeting economies are large, relatively well developed, and have more developed domestic financial systems compared to their counterparts, suggesting that these attributes should be carefully considered by other emerging market countries thinking of adopting this regime. Moreover, experience has shown that a strong fiscal position and entrenched macroeconomic stability are equally important elements of the foundation for successful inflation targeting.

In contrast to industrial countries, emerging market countries tend to prefer a more formal institutional framework in support of inflation targeting. The legal frameworks of all inflation targeting countries explicitly set price or currency stability as the primary objective of the central bank and grant it instrument independence. Emerging market countries usually modify the central bank legal framework before adopting inflation targeting, however, and all emerging market countries explicitly limit central bank financing of government deficits in the primary market. The more formal institutional frameworks for inflation targeting in emerging market countries may reflect their much higher and more variable rates of inflation compared to industrial countries, less developed financial systems, greater vulnerability to inflationary monetization of government debt, and greater susceptibility to exchange rate crises.

Differences in the operation and design of inflation targeting between emerging market and industrial countries are another theme of this paper. Central banks in emerging market countries rely less on statistical models in the conduct of monetary policy.
They appear to intervene more frequently in foreign exchange markets than their counterparts in industrial countries. The design of inflation targets in emerging market countries is characterized by shorter horizons, and by target bands rather than point targets. These differences may also reflect structural differences with industrial countries. Ongoing structural changes in underlying economic relationships are more prevalent in emerging market countries, which are inclined to be more vulnerable to shocks, especially volatile capital flows.

Most central banks in emerging market countries have taken important organizational steps to enhance their capacity to apply greater judgment and foster transparency and accountability. These steps can be particularly challenging for emerging market central banks that have traditionally operated with controls and regulations and have been reluctant to communicate their policy intentions and economic outlooks. Most of these banks have improved their governance structure by incorporating a broader range of perspectives into the monetary policy decision-making process, and by reforming their organizational structure with a view to delegating authority.

Finally, during the transition to full-fledged inflation targeting, several emerging market countries have confronted the challenge of disinflating to the long-run inflation objective. The experiences of Chile, Israel, and Poland suggest that a gradual shift from a crawling exchange rate regime to an inflation targeting framework is feasible given supportive economic and fiscal policies to manage the transition and minimize the risk of saddling the central bank with conflicting objectives. 


\section{Introduction}

$\mathrm{n}$ recent years, several emerging market countries

have followed industrial countries in adopting monetary policy frameworks that formally target inflation. ${ }^{1}$ Brazil, Chile, the Czech Republic, Israel, Poland, and South Africa have adopted inflation targeting, while Mexico, Thailand, and others are moving to this framework. This trend has led to increased demand by emerging market countries for technical assistance on the adoption of inflation targeting.

This paper summarizes the advice of the IMF's Monetary and Exchange Affairs Department for emerging market countries on the institutional and operational practicalities of inflation targeting. The trade-offs raised in formulating inflation targeting frameworks in emerging market countries are briefly examined, and the approaches to these trade-offs by countries that have already adopted inflation targeting frameworks are described. This paper draws heavily on the body of knowledge formed by the years of industrial country experience with inflation targeting, as well as the more recent formulation of inflation targeting frameworks by emerging market countries. Of course, common practice is not necessarily the best practice, and experience over several business cycles and under adverse conditions will be needed to draw firm conclusions regarding many of the key aspects of inflation targeting. Despite these caveats, and given the demonstrated preference by a growing number of emerging market countries for inflation targeting, it seems worthwhile to begin to draw on this accumulated experience as a basis for technical advice.

The increasing number of emerging market countries that have adopted inflation targeting suggests that this framework offers advantages over monetary and exchange rate anchors. ${ }^{2}$ First, inflation targeting

\footnotetext{
Inflation targeting in emerging market countries is the subject of Blejer and others (2000); Masson and others (1997); Mishkin (2000); and the background papers for the seminar "Implementing Inflation Targets," held in Washington in March 2000 and available via the Internet at www.imf.org/external/pubs/ft/seminar/2000/targets/index.htm.

${ }^{2}$ Bernanke and others (1999); Leiderman and Svensson (1995); and Svensson (1997).
}

helps shift the public's attention away from shortterm interventionist policies for which monetary policy is ill-suited, toward low and stable inflation, which supports macroeconomic stability and economic growth. Second, inflation targeting greatly enhances the accountability and discipline of monetary policy, as well as fiscal policy. Third, a wellestablished inflation targeting framework provides the central bank with the scope to respond to shortrun developments, but with less of a threat to its long-run, inflation-fighting credibility. Finally, inflation targeting helps motivate institutional reform of the central bank, as well as provide an impetus for structural reforms more generally, especially in the context of disinflation. Of course, inflation targeting also has potential disadvantages, including monetary instrument instability if the framework is overly rigid, the need for a strong fiscal position, and possible exchange rate volatility, especially in the case of small open economies.

The experience of the countries examined in this paper suggests that the foundations for successful, fullfledged inflation targeting are built on the following:

- a strong fiscal position and entrenched macroeconomic stability;

- a well-developed financial system;

- central bank instrument independence and a mandate to achieve price stability;

- reasonably well understood channels between policy instruments and inflation;

- a sound methodology for devising inflation forecasts; and

- transparent policies to build accountability and credibility.

Of course, many of these elements, especially a strong fiscal position, are needed for sound monetary policy regardless of the policy objective. At the same time, they need not be considered prerequisites for beginning the transition toward full-fledged inflation targeting. Indeed, many emerging market countries turn to pre-announced inflation targets, as 
opposed to full-fledged inflation targeting, as the least bad of the available policy objective choices.

The countries that are discussed as practitioners of inflation targeting in this paper are those considered to have adopted most of the elements of a fullfledged inflation targeting framework. The identification of these countries is not always clear-cut. ${ }^{3}$ Many countries regularly pre-announce inflation targets, but at the same time adhere to other policy objectives such as monetary targets or some form of exchange rate targeting. Full-fledged inflation targeting countries, in contrast, commit to subordinating other policy objectives to the inflation target, essentially use an inflation forecast as the intermediate guide to monetary policy, and operate policy in a transparent framework that fosters accountability.

This paper assumes that the starting date for the adoption of inflation targeting by a country is the earliest date by which that country is deemed to have had in place most of the elements of an inflation targeting framework. ${ }^{4}$ Key elements of the framework that can determine the starting date are announcement of the details of the framework, and abandonment or broad widening of an exchange rate band.

\footnotetext{
${ }^{3}$ See the survey of central banks' usage of inflation targets contained in Fry and others (2000). Some 54 of the 93 surveyed central banks reported that they announce inflation targets; only 16 considered themselves to be inflation targeters, however.

${ }^{4}$ The exact starting date of the inflation targeting framework is a matter of debate for some emerging market countries. For example, Chile and Israel operated with both inflation targets and crawling exchange rate bands for many years. Over time, it became increasingly clear that the inflation target was the dominant objective as the exchange rate band was widened and as conflicts between the inflation targets and the exchange rate band were mainly resolved in favor of the former. Given the gradual shift between frameworks, however, it is difficult to pinpoint with any accuracy the date by which these countries became full-fledged inflation targeters. Consequently, for the purposes of this paper, we set the start dates for full-fledged inflation targeting for Chile as September 1999 (date of abandonment of the crawling exchange rate regime, even though inflation targets were first announced in 1990); and for Israel as June 1997 (date when the crawling exchange rate band was widened to a point where conflicts between the exchange rate band and the inflation target were deemed minimal, even though inflation targets were first announced in 1991)
}

This paper also examines the period of transition to full-fledged inflation targeting, which is initiated by announcement of intention to adopt an inflation targeting framework or by announcement of an inflation target. Two important policy challenges arise during the transition: how to move from a fixed exchange rate regime to inflation targeting and how to revise the framework on an ongoing basis in a disinflationary setting.

The differences between the six emerging market inflation targeting countries and other emerging market countries may shed some light on the preferred starting point for inflation targeting (see Appendix I). The six emerging market economies that target inflation are large - they rank in the top quintile of the 118 developing countries (all developing countries in the World Economic Outlook database excluding small island countries and oil exporters) by total GDP. All six of these countries are relatively well developed, ranking in the top quintile of developing countries by GDP per capita. Finally, these six countries have better developed domestic financial systems compared to the other emerging market countries-based on standard indicators of financial market development and their use of market-based instruments of monetary policy and short-term interest rate operating targets.

The remainder of this paper is organized as follows. Section III outlines the institutional details of inflation targeting frameworks. Section IV examines the transition to full-fledged inflation targeting. Section $\mathrm{V}$ discusses the operational practices of inflation targeting central banks. The implications of inflation targets for the organizational structure of central banks are considered in Section VI. Section VII concludes the paper. Appendix I compares macroeconomic data for emerging market countries that target inflation with comparable data for other emerging market countries and for inflation targeting industrial countries. Appendix II reports in some detail on the institutional aspects of inflation targeting in the six emerging market and seven industrial country targeters, and Appendix III reviews their experiences under inflation targeting. 


\section{Institutional Framework}

$\mathbf{T}$ his section summarizes the institutional framework in support of inflation targeting, including the central bank legal framework, the design of the inflation target, and accountability and transparency mechanisms. In contrast to industrial countries, emerging market countries tend to have a more formal institutional framework.

\section{Central Bank Legal Framework}

The legal framework for inflation targeting central banks defines the objectives of monetary policy and provides central banks with the scope to meet these objectives. Monetary policy is characterized by an inherent principal-agent (government-central bank) problem owing to information asymmetries and policy lags (Walsh, 1995; Bernanke and others, 1999). The typical inflation targeting legal framework ameliorates the principal-agent problem by giving the central bank a mandate to achieve domestic stability of the currency and the discretion to formulate policies to attain this mandate (instrument independence).

Central bank legislation for inflation targeting countries varies in terms of the clarity of the monetary policy objective and the weight attached to domestic price stability. The timing and magnitude of changes to central bank legal frameworks reflect the trade-off between the efforts needed to garner public support and the credibility gains from new legislation (Walsh, 1995). In Israel, Canada, and many other countries, public support for inflation targeting was not widespread upon the introduction of the target. Only a few countries (New Zealand, Poland, and Spain) had legislation in place that provided the central bank with a clear mandate for achieving price stability as the primary objective of monetary policy (Table 3.1). ${ }^{5}$ In most industrial countries, the central bank's mandate comprises a wider set of economic

\footnotetext{
${ }^{5}$ All references to Finland and Spain in this paper are for the period prior to the introduction of the single European currency (euro) in January 1999.
}

objectives but, in practice, domestic price stability has become the primary monetary policy objective. The four west European inflation targeters (Finland, Spain, Sweden, and the United Kingdom) are all members of the European Union and therefore have revised their central bank legislation in accordance with the 1993 Maastricht Treaty on European Union.

Monetary policy objectives are defined in the central bank legal framework of most emerging market countries so as to allow for an internal and external dimension of currency stability. All emerging market countries, with the exception of Poland, include as a central bank objective "stabilizing the value of the currency." 6 This provides for domestic (price stability) and external (exchange rate stability) perspectives, reflecting the role that fixed exchange rates or crawling pegs have played in most of these countries. In practice, the emphasis of monetary policy objectives has shifted toward domestic price stability in tandem with increases in the degree of exchange rate flexibility.

Independence of monetary policy instruments is guaranteed in the legal frameworks of all inflation targeters (Table 3.1). All emerging market countries established instrument independence in their central bank legislation prior to adopting an inflation targeting framework. Among industrial countries, two have made changes only recently (Sweden and the United Kingdom) and three formally allow the government to override the central bank's policy decisions (Australia, Canada, and New Zealand), although in none of the latter countries has the government made use of the override provision over the last 30 years. The United Kingdom also provides an example of how instrument independence can help reduce inflation expectations. After the Chancellor of the Exchequer announced plans to give the Bank of England operational independence on May 6, 1997, inflation expectations receded significantly (Bank of England, 1997).

\footnotetext{
${ }^{6}$ The Act of the Czech National Bank is currently being amended; the proposed amendments would replace currency stability with domestic price stability as the primary objective.
} 


\section{Table 3.I. Central Bank Legal Frameworks}

\begin{tabular}{|c|c|}
\hline Central Bank Legal Framework & Countries \\
\hline \multicolumn{2}{|l|}{ Objectives of monetary policy } \\
\hline Currency stability as primary objective & Czech Republic, Finland \\
\hline $\begin{array}{l}\text { Domestic price stability as primary } \\
\text { objective }\end{array}$ & New Zealand, Poland, Spain, Sweden, United Kingdom \\
\hline Currency stability plus other objectives & Brazil,Australia, Canada, Chile, Israel, South Africa \\
\hline Instrument independence & $\begin{array}{l}\text { Australia,' Brazil, Canada,' Chile, Czech Republic, } \\
\text { Finland, Israel, Poland, New Zealand,' South Africa, } \\
\text { Spain, Sweden, United Kingdom }\end{array}$ \\
\hline \multicolumn{2}{|l|}{ Financing of government deficits } \\
\hline Limited & Canada, Czech Republic, South Africa \\
\hline Not allowed & Brazil, Chile, Finland, Israel, Poland, Spain, Sweden \\
\hline
\end{tabular}

Central bank legal frameworks in all emerging market countries that target inflation explicitly limit or prohibit financing of government spending. These limits reflect the experience of high inflation induced by the monetization of fiscal deficits. The higher levels of government debt for emerging market countries relative to industrial countries imply that the former are more vulnerable to inflation arising from monetization of a given level of government spending (Kumhoff, 2000; see Appendix I). Limits on central bank fiscal financing do not preclude central bank purchases of government securities on secondary markets.

Most industrial countries, however, did not see a pressing need to immediately revise their central bank legislation. Finland and Spain prohibited financing of government deficits when they adjusted their central bank legislation in line with the requirements of the second stage of European Economic and Monetary Union; Sweden undertook the change when it amended its central bank legislation in 1999. ${ }^{7}$

Emerging market countries have preferred to have a central bank legal framework in place that yields a high degree of independence before introducing inflation targeting. Legislation in industrial countries tends to be more diverse and has often been revised

\footnotetext{
${ }^{7}$ In stage two of European Economic and Monetary Union, which entered into force on January 1, 1994, member countries were obliged to eliminate incompatibilities between their national legislation, on the one hand, and the Maastricht Treaty and the European System of Central Banks/European Central Bank Statute on the other, including in the area of central bank independence.
}

after inflation targeting has been adopted. The need for enhanced credibility in emerging market economies stems from their greater vulnerability to shocks as well as, in some cases, a previous history of high rates of inflation (Appendix I). Of course, the contribution of central bank legislation to building credibility should be kept in perspective, as a central bank will acquire credibility mainly by consistently matching word to deed (Blinder, 1998).

\section{Inflation Target Design}

Inflation targets are designed based on countryspecific factors such as the degree of central bank credibility, the country's vulnerability to shocks, and/or data availability. Several countries have adjusted the inflation target design in response to changes in these factors.

\section{Formal Announcement of the Target}

Inflation targets for eight of the 13 inflation targeting countries are announced either by the government or jointly by the government and the central bank. This can strengthen the target's credibility by indirectly committing the government to operate fiscal policy in a way that supports achievement of the inflation objective. Debelle and Fischer (1994) conclude that a central bank should be assigned a goal by the government because the government represents the society's preferences, while the central bank, depending on how much independence it has, might choose a target which the government believes is overly stringent. Governments may have a 


\begin{tabular}{ll} 
Table 3.2. Announcement of Inflation Targets \\
\hline Target Announced by & \multicolumn{1}{c}{ Countries } \\
\hline Government & Brazil, Israel, United Kingdom \\
Central bank & Chile, Finland, Poland, Spain, Sweden \\
Jointly by government and central bank & Australia, Canada, Czech Republic, New Zealand, \\
& South Africa \\
\hline Sources: Central bank websites. & \\
\hline
\end{tabular}

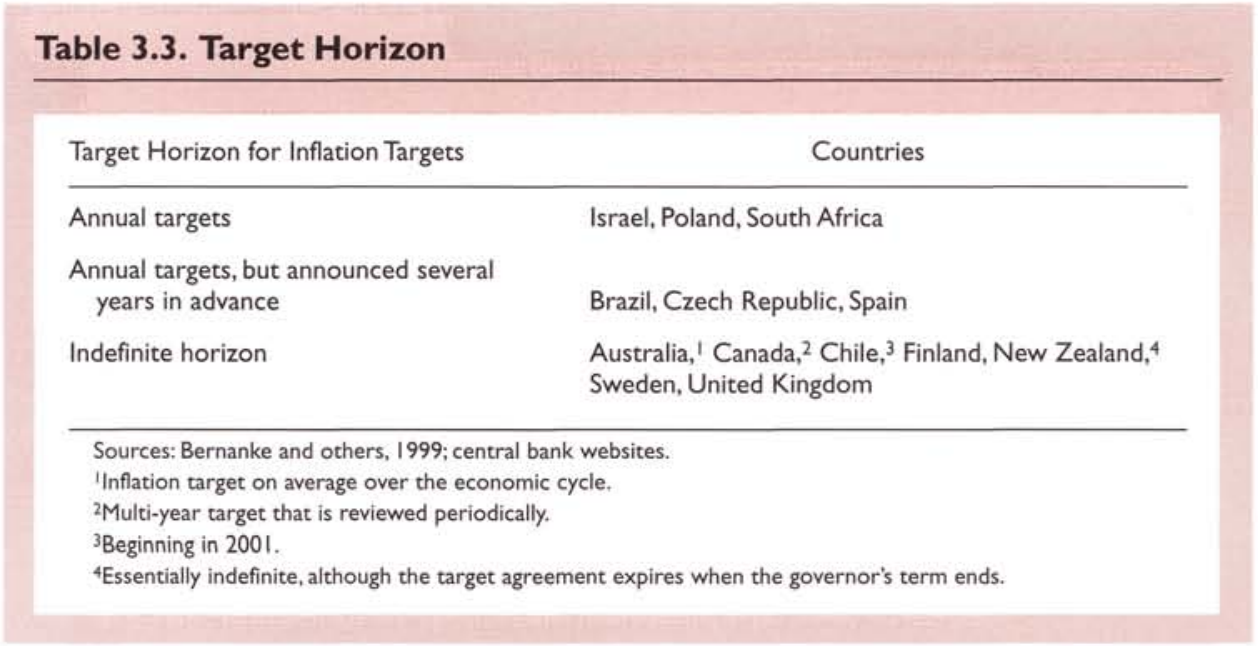

short-term horizon and thus favor targets that might be above the socially optimal long-term rate of inflation, however. This can be mitigated either by a joint target announcement or by having the central bank play an active role in discussing the consequences of inflation with the government and society. For example, while the Bank of Israel ultimately accepts the target announced by the government, it has not shied away from publicly indicating its preferences regarding the appropriate target rate of inflation when its views have differed from those of the government. Only in Brazil, Israel, and the United Kingdom are inflation targets formally set solely by the government, usually after consulting with the central bank (Table 3.2).

Central banks typically announce inflation targets in countries in which legislation governing central banks provides them with an explicit mandate for price stability as the primary objective of monetary policy, but does not specify a target (Poland, Spain, and Sweden). The central banks of Chile and Finland, whose policy objectives are defined in broad terms as currency stability, also announce their infla- tion targets, indicating the central banks' ability to interpret the legal mandate as domestic price stability. By announcing inflation targets, central banks ensure their accountability to the public and boost the credibility of monetary policy. Credibility is enhanced because the announcement symbolizes the delegation by governments in those countries of authority for monetary policy objectives to the central bank.

\section{Target Horizon}

When inflation is at the desired long-run objective, the length of the policy horizon often reflects policy transmission lags and a desire to avoid excessive variations in monetary instruments and (consequently) output. The target horizon defines the period over which the central bank commits to achieving the targeted inflation rate. For Australia, Chile (beginning in 2001), New Zealand, Sweden, and the United Kingdom, which set targets at or near their longer-run desired rate of inflation, the horizon is more than one year (Table 3.3). Long-term horizons have the advantage of giving the central bank 
more scope to respond to shocks (e.g., to keep output stable) and help cement inflationary expectations. Indeed, short target horizons and lead times may generate instrument instability if the horizon is short in relation to policy lags.

For countries with inflation above the long-run rate, short target horizons can accelerate the pace of disinflation. Monetary policy can respond to shocks by adjusting the inflation target itself, rather than just the policy stance. Many emerging market countries have spelled out a disinflation path defined by annual targets in addition to their long-run inflation objective. The entire path is either announced for several years in advance (e.g., Czech Republic) or year-by-year (e.g., Poland). In general, setting only annual targets can make it easier to lock in successes in disinflation if they are achieved faster than expected (see Section IV). Moreover, an annual target can leave more room to absorb short-run inflationary shocks and dampen output fluctuations because the central bank has not committed itself to a disinflation path that in retrospect may turn out to be overly ambitious.

Rolling year-over-year inflation rates are the gauge by which central banks in industrial countries (except the Reserve Bank of Australia) and in most emerging market countries are held accountable. Central bank inflation reports or monetary policy reports compare the targets with monthly or quarterly inflation outcomes, even though in several cases the formal framework does not always explicitly define the relevant checkpoints. The Reserve Bank of Australia's framework only requires the central bank to achieve the inflation target, on average, over the course of an economic cycle. The Czech Republic, Israel, and Poland have formulated annual December-on-December targets-reflecting the role their exchange rate targets have played in setting the path for disinflation. ${ }^{8}$ However, these countries also discuss inflation performance within the year in their central banks' inflation reports. Until recently, Chile confined its assessment of meeting the target to the end-of-year figure, but since May 2000 publishes an inflation report, which includes an assessment of inflation performance during the year.

Periodic checkpoints for public observance help monitor the performance of inflation relative to the target. Regular monitoring of the inflation target provides the greatest degree of accountability. As soon as - or even before- the target path is breached, the public can then expect the central bank to explain the

${ }^{8}$ Polish authorities announced in April 2000 that the Polish currency (zloty) would be allowed to float without a crawling exchange rate band. The central bank does not intend to make any changes to its monetary framework as a consequence of abolishing the crawling exchange rate band. underlying reasons for the breach and the policy actions in response. To facilitate monitoring by the public, inflation targets are typically defined as yearover-year changes on a rolling monthly or quarterly basis. Limiting the checkpoint to once a year, for example, by defining the inflation target as the December-over-December change, may reduce the central bank's accountability for the inflation outcome over the course of the year and may be unrepresentative of the inflation performance during the entire year.

\section{Price Index}

The choice of the appropriate price index can be framed in terms of the trade-offs between controllability and credibility. There is no viable alternative to a consumer price index (CPI) because it is the best and most up-to-date price index available, the focus of expectations, easily understood by the public, and perceived to be less susceptible to manipulation by the central bank. ${ }^{9}$ Data manipulation in the past has been a concern in some countries. However, because the CPI often includes components that are beyond the control of the central bank (such as administrative prices, terms of trade, and indirect taxes) and interest charges, a policy tightening may create a spurious rise in inflation.

These problems can be addressed by use of a core CPI that excludes some or all of these factors. There is a range of techniques available for constructing core inflation measures and most countries that use these measures construct and monitor more than one (Roger, 1998). Compilation of the CPI and core inflation by an independent agency, typically the country's statistical agency, can improve credibility by avoiding the perception that the central bank manipulates the data. In all countries surveyed here, the national statistical agency calculates the CPI, and in all of the surveyed countries except Canada, the core measure. In practice, core measures are the focus of policy formulation and accountability; for example, a breach of the target range by core inflation is considered more serious than a breach of the CPI.

Most emerging market countries use the CPI because it is familiar to the public and therefore enhances credibility (Table 3.4 ). Country specific reasons usually provide the motivation for using the CPI (retail price index in the case of the United Kingdom). A core inflation measure (the definition of which varies significantly across countries de-

\footnotetext{
${ }^{9}$ An alternative to the consumer price index is the GDP-deflator, which captures all prices of final goods and services produced within the national territory. The disadvantage of using the GDPdeflator in an inflation targeting framework is the lack of early data availability and the frequent data revisions which would impede transparency and credibility.
} 


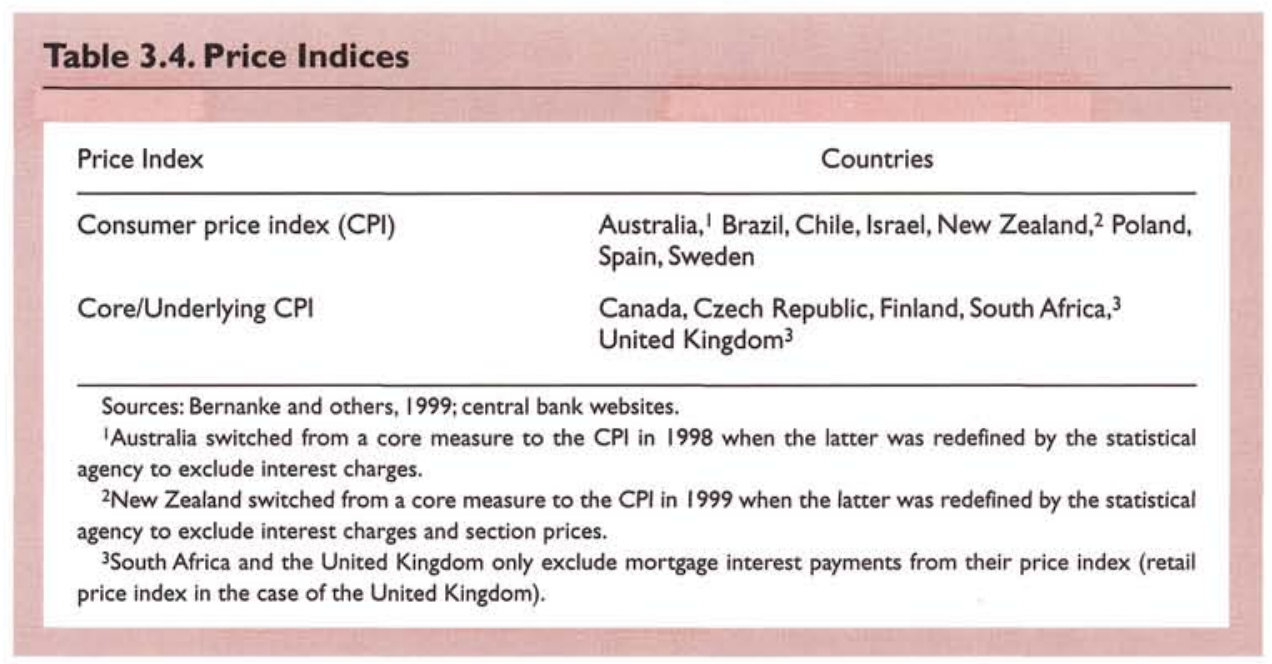

pending on individual circumstances) is always simultaneously monitored, however, since it can be a better predictor of CPI in the future than today's total CPI measure. For example, in Israel, the share of administrative prices and extremely volatile prices (fruits and vegetables, and housing) is about 40 percent; nevertheless, the CPI is used because it is the benchmark for indexation in the economy and it also precludes manipulation by the central bank. Brazil uses the CPI to reassure the public given the country's history of hyperinflation. Switching to a core measure can be advantageous once the country's statistical agency has completed construction of such a measure and it has been accepted by the public and private sectors.

The CPI can be nationwide or regional in coverage. The choice is mainly driven by data timeliness and the extent to which the index is widely followed by the public. As a result, most countries focus on national CPI indices, although Brazil and South Africa use indices with narrower coverage (mainly urban areas).

\section{Escape Clauses}

The choice and design of escape clauses, which set the conditions under which inflation target breaches might be tolerated, also involve trading off flexibility and credibility. Currently, only Canada, the Czech Republic, New Zealand, and South Africa have escape clauses in their inflation targeting frameworks to enhance flexibility (see Appendix Tables A2.1 and A2.2). Escape clauses spell out in advance the circumstances under which targets may be missed and can either require the central bank to indicate the time frame over which it would attempt to return to the inflation target path or communicate a new target path. Among the downsides of these clauses are their largely discretionary invocation and their inability to capture all potential shocks. Attempts to use them in situations that are not clear-cut might therefore undermine the accountability and credibility of the inflation targeting framework. To date, escape clauses have only been activated in New Zealand in 1990-91 and 1993-94 when oil and timber prices were excluded from the calculation of underlying inflation (Bernanke and others, 1999).

\section{Target Range or Point}

A target range rather than a point can provide the central bank with more flexibility to respond to shocks and permit a range of discretion in the context of other objectives. Clear-cut target breaches are less likely. Moreover, the width of the range signals in advance how much tolerance the central bank has for fluctuations in inflation around the midpoint, recognizing that a point will not be hit exactly. Still, flexibility will depend on the width of an announced target range relative to the scale of deviation that is acceptable under a point target. The wider the range, the less clear is the focus for inflation expectations and the commitment of the central bank to a clear target. Moreover, policymakers may be concerned that, in practice, the top of the range might become the target rather than the midpoint. Some countries have preferred to emphasize point targets (Finland, Spain, and the United Kingdom) or point targets with a margin (Brazil and Sweden) because a point target is more readily understood by the public (Table 3.5). For Australia, the $2-3$ percentage point target range is viewed by the Reserve Bank of Australia as a "thick point" rather than as a target range in the sense that it is not a range within which inflation can be maintained in all circumstances (Debelle and Stevens, 1995). 
Table 3.5. Point Target or Target Range

\begin{tabular}{ll}
\hline Point or Range & \multicolumn{1}{c}{ Countries } \\
\hline $\begin{array}{l}\text { Point target } \\
\text { Point target with a range }\end{array}$ & $\begin{array}{l}\text { Finland, Spain, United Kingdom } \\
\text { Brazil, Sweden }\end{array}$ \\
$\begin{array}{l}\text { Target range of 2 percentage points or less } \\
\text { Australia, Canada, Chile,' Czech Republic, Israel, } \\
\text { Poland }\end{array}$ \\
$\begin{array}{l}\text { Target range of more than 2 percentage } \\
\text { points }\end{array}$ & New Zealand, South Africa \\
\hline $\begin{array}{l}\text { Sources: Central bank websites. } \\
\text { 'Beginning in 200I. }\end{array}$ &
\end{tabular}

The trade-off between a narrow and a wide range depends on the frequency and severity of shocks and the central bank's credibility. To provide clear guidance for inflation expectations, most central banks have set either point targets or narrow target ranges of two percentage points or less. These arrangements are favored by industrial and emerging market economies alike. Important exceptions are Brazil, New Zealand, and South Africa, which have opted for wider ranges to compensate for their targeted price indices including a number of volatile items that are beyond the influence of the central bank.

The range width has been adjusted in some countries (Table 3.6). Some emerging market countries that have moved gradually from a crawling exchange rate band to an inflation targeting framework started with narrow targets to emphasize commitment of monetary policy and focus inflation expectations. Thereafter, they have widened the target range once the broadening of exchange rate bands has begun to boost the influence of passthrough effects on domestic prices. For example, Israel's inflation target band was widened at the same time as the band for the exchange rate in order to limit the number of target breaches (see Appendix Table A2.1). In New Zealand, the inflation target band was widened by one percentage point, to 0-3 percent (from 0-2 percent) in December 1996. This followed several years of higher interest rates in response to upward pressure on inflation. In response, the incoming coalition government sought and obtained a widening of the target range. ${ }^{10}$

\footnotetext{
${ }^{10}$ The widening of the target range was a compromise made by the Reserve Bank of New Zealand with the incoming coalition government.
}

\section{Accountability and Transparency}

All inflation targeting central banks operate in a transparent fashion because public accountability is essential to successful inflation targeting. The need for explicit accountability mechanisms in inflation targeting is due to the lag between monetary policy actions and inflation, which makes it difficult to monitor policy commitment on an ongoing basis. This stands in marked contrast to exchange rate and monetary targeting regimes, where adherence to the targets can be readily monitored on an ongoing basis. In addition, accountability helps insulate monetary policy from outside political pressures.

Inflation targeting central banks regularly disclose their views on inflation performance, the motivations behind monetary actions, and the outlook for inflation. They prepare regular reports to account for their performance in achieving their inflation targets (Table 3.7). In all cases, the reports are furnished to government authorities to meet accountability requirements and are published in print as well as on central bank websites. ${ }^{11}$ The reports provide detailed accounts of recent economic and financial developments and their effects on the behavior of inflation relative to target, explain the motivations underlying recent monetary actions, and in many cases, discuss the outlook for inflation for the next 12 to 24 months. Often they are supplemented by public appearances of senior central bank officials before parliamentary committees, where the bank officials may be asked to elaborate on key points of interest. ${ }^{12}$ In addition,

\footnotetext{
${ }^{11}$ Chile began publishing inflation reports in May 2000; the information in this paper on the Central Bank of Chile's past inflation targets was retrieved from back issues of the Bank's Annual Report.

${ }^{12}$ For more information on the transparency practices consistent with the Code of Good Practices on Transparency in Monetary and Financial Policies, see IMF (2000).
} 


\begin{tabular}{|c|c|c|c|}
\hline \multicolumn{2}{|c|}{ Emerging Market Countries } & \multicolumn{2}{|c|}{ Industrial Countries } \\
\hline Brazil & $\begin{array}{l}1999: 8 \%( \pm 2 \%) \\
2000: 6 \%( \pm 2 \%) \\
2001: 4 \%( \pm 2 \%)\end{array}$ & Australia & $\begin{array}{l}2-3 \% \text { on average over the economic } \\
\text { cycle }\end{array}$ \\
\hline Chile' & $\begin{array}{l}\text { 1991: 18\% } \\
\text { 1992: 15-20\% } \\
\text { 1993: } 10-12 \% \\
\text { 1994: } 9-11 \% \\
1995: 8 \% \\
1996: 6.5 \% \\
1997: 5.5 \% \\
1998: 4.5 \% \\
1999: 4.3 \% \\
2000: 3.5 \% \\
2001: 2-4 \%\end{array}$ & Canada & $\begin{array}{l}\text { Dec. } 1991: 3-5 \% \text { (excluding goods } \\
\text { and services tax) } \\
\text { Dec. 1992: } 2-4 \% \\
\text { June 1994: } 1.5-3.5 \% \\
\text { Since Dec. } 1995: 1-3 \%\end{array}$ \\
\hline Czech Republic & $\begin{array}{l}1998: 5.5-6.5 \% \\
1999: 4-5 \% \\
2000: 3.5-5.5 \% \\
2001: 2-4 \% \\
2005: 1-3 \%\end{array}$ & Finland & Annual average of $2 \%$ by 1995 \\
\hline Israel & $\begin{array}{l}1992: 14-15 \% \\
1993: 10 \% \\
1994: 8 \% \\
1995: 8-11 \% \\
1996: 8-10 \% \\
1997: 7-10 \% \\
1998: 7-10 \% \\
1999:<4 \% \\
2000: 3-4 \% \\
2001: 3-4 \%\end{array}$ & New Zealand & $\begin{array}{l}\text { 1990: } 3-5 \% \\
1991: 2.5-4.5 \% \\
1992: 1.5-3.5 \% \\
\text { 1993-1996:0-2\% } \\
\text { Since Dec. } 1996: 0-3 \%\end{array}$ \\
\hline Poland & $\begin{array}{l}1998:<9.5 \% \\
1999: 6.6-7.8 \% \\
2000: 5.4-6.8 \% \\
2003:<4 \%\end{array}$ & Spain & $\begin{array}{l}\text { June 1996: } 3.5-4 \% \\
\text { Dec. } 1997:<3 \% \\
\text { 1998: } 2 \%\end{array}$ \\
\hline \multirow[t]{2}{*}{ South Africa } & $2002: 3-6 \%$ & Sweden & Since $1995: 2 \%( \pm 1 \%)$ \\
\hline & & United Kingdom & $\begin{array}{l}\text { 1992-1995: } 1-4 \% \\
\text { Since 1996: } 2.5 \%\end{array}$ \\
\hline
\end{tabular}

some countries (for example, the Czech Republic and Sweden) publish the minutes of monetary policy meetings,

Reporting of the details of inflation outlooks varies across countries reflecting the trade-off between providing more information versus the cost of having to revise it frequently due to forecast errors. Most inflation targeting central banks provide a comprehensive review of economic and financial developments both at home and abroad - as well as the impact of these developments on domestic inflation, but the coverage of their inflation outlooks varies significantly across countries. Central banks in Brazil, Chile, Sweden, and the United Kingdom provide "fan" charts of their inflation outlooks to illustrate in a stylized, probabilistic fashion the amount of uncertainty surrounding their outlooks over a two-year horizon. The central banks of Chile, New Zealand, Sweden, and the United Kingdom devote a section of their reports to discussing the risks associated with their inflation outlooks, and the central banks of Brazil, New Zealand, and the United Kingdom even go so far as to publish the results of model-based economic projections. Central banks in other countries, however, 
Table 3.7. Communication Vehicles Employed by Inflation Targeters

\begin{tabular}{|c|c|c|c|c|c|c|}
\hline \multirow[b]{2}{*}{$\begin{array}{l}\text { Inflation Targeting } \\
\text { Countries }\end{array}$} & \multirow[b]{2}{*}{$\begin{array}{c}\text { Announce } \\
\text { Monetary } \\
\text { Actions via } \\
\text { Press Release }\end{array}$} & \multicolumn{3}{|c|}{ Inflation/Monetary Policy Reports } & \multicolumn{2}{|c|}{ Other Means of Communication } \\
\hline & & Frequency & $\begin{array}{l}\text { Review Inflation } \\
\text { Performance and } \\
\text { Monetary Actions }\end{array}$ & $\begin{array}{l}\text { Inflation } \\
\text { Outlook }\end{array}$ & $\begin{array}{c}\text { Publish: } \\
\text { Research/Models } \\
\text { Used for } \\
\text { Inflation Outlook }\end{array}$ & $\begin{array}{c}\text { Media and } \\
\text { Other Public } \\
\text { Presentations }\end{array}$ \\
\hline \multicolumn{7}{|l|}{ Emerging Markets } \\
\hline Brazil & Yes & Quarterly & Yes & $\begin{array}{l}\text { Two-year fan } \\
\text { charts with } \\
\text { discussion }\end{array}$ & Yes/Nol & Yes \\
\hline Chile & Yes & $\begin{array}{l}\text { Three times a } \\
\text { year }\end{array}$ & Yes & $\begin{array}{l}\text { Two-year fan } \\
\text { charts with } \\
\text { discussion }\end{array}$ & Yes/Yes & Yes \\
\hline Czech Republic & Yes & Quarterly & Yes & $\begin{array}{l}\text { One-year range } \\
\text { with discussion }\end{array}$ & No/No & Yes \\
\hline Israel & Yes & Semi-annually & Yes & No estimates & Yes/Some & Yes \\
\hline Poland & Yes & Quarterly & Yes & $\begin{array}{l}\text { Qualitative } \\
\text { discussion }\end{array}$ & Yes/No & Yes \\
\hline \multicolumn{7}{|l|}{ Industrial Countries } \\
\hline Australia & Yes & $\begin{array}{l}\text { Semi-annually } \\
\text { with quarterly } \\
\text { updates }\end{array}$ & Yes & $\begin{array}{l}\text { Two-year point } \\
\text { estimate with } \\
\text { discussion }\end{array}$ & Yes/Yes & Yes \\
\hline Canada & Yes & $\begin{array}{l}\text { Semi-annually } \\
\text { with quarterly } \\
\text { updates }\end{array}$ & Yes & $\begin{array}{l}\text { One-year point } \\
\text { estimate with } \\
\text { discussion }\end{array}$ & Yes/Yes & Yes \\
\hline New Zealand & Yes & Quarterly & Yes & $\begin{array}{l}\text { Detailed multi- } \\
\text { year economic } \\
\text { projection with } \\
\text { discussion }\end{array}$ & Yes/Yes & Yes \\
\hline Sweden & Yes & Quarterly & Yes & $\begin{array}{l}\text { Two-year point } \\
\text { fan charts with } \\
\text { discussion }\end{array}$ & Yes/Yes & Yes \\
\hline United Kingdom & Yes & Quarterly & Yes & $\begin{array}{l}\text { Two-year fan } \\
\text { charts with } \\
\text { discussion }\end{array}$ & Yes/Yes & Yes \\
\hline
\end{tabular}

are more reticent. Given the amount of uncertainty surrounding their inflation outlooks, they offer instead qualitative discussions of their inflation outlooks with at most point-estimates of future inflation for the following 12-24 months.

Policy actions are announced immediately by press release to enhance transparency. Typically, central banks announce a change in policy stance by way of a press release and include a summary of the factors motivating the change (or, in some cases, no change). Messages in published reports are often reinforced by presentations to external groups. Inflation targeting central banks, like central banks in a number of other countries, are increasingly supplementing their official reports on economic conditions with regular presentations by senior officials to a wide variety of audiences (including the news media). This fosters a broader understanding of the objectives of monetary policy and the performance of the central bank. In Brazil, senior officials give lectures and presentations to the private sector and the media to educate them about the objectives and conduct of monetary policy, while in Canada such presentations include media briefings, speeches to public gatherings, as well as outreach sessions with various private-sector groups where there can be two-way exchanges of information on economic and financial conditions.

Other forms of communication are also used to enhance accountability. Inflation targeting central banks in industrial countries - as well as those in Brazil, Chile, Israel, and Poland-are making a 
conscious effort to publish internal research studies to foster greater public understanding of underlying economic and financial relationships that drive their inflation outlooks. These banks are making a greater effort to disseminate research papers over the Internet and to sponsor conferences where central bank researchers and external experts can meet to discuss issues of interest to the authorities. So far, however, only central banks in industrial countries, Chile, and Israel have published details on the models used to produce their inflation outlooks. Other emerging market countries have been reluctant to publish details of their models because their models are still being developed and may evolve significantly over time in line with the evolution of their economies. 


\section{Transition Issues}

M ost emerging market countries have undergone a period of transition prior to adopting a full-fledged inflation targeting framework (Table 4.1). Policymakers have marked the beginning of the transition period by announcing the intention to adopt inflation targeting or by announcing an inflation target in the context of an exchange rate band. The transition period ends when most of the elements of a full-fledged inflation targeting framework are in place. Emerging market countries' transitions to full-fledged inflation targeting have ranged from slow (Chile and Israel) to fast (Brazil, Czech Republic, Poland, and South Africa).

\section{Inflation Trends}

Most industrial countries have adopted a fullfledged inflation targeting framework at a time when inflation was declining (Table 4.2). The only exception is Canada, where the move toward inflation tar- geting was timed to mitigate the potential inflationary impact of the introduction of a new indirect tax. All of the industrial countries adopted inflation targeting during or just before an economic downturnas gauged by output gaps recorded in the World Economic Outlook database. Moreover, the adoption of inflation targeting by the European countries, notably Sweden and the United Kingdom, occurred in the wake of the breakdown of the Exchange Rate Mechanism of the European Monetary System and the abandonment of exchange rate pegs.

The choice between a gradual and fast track transition for emerging market countries reflects the level of inflation at the beginning of the transition (Table 4.3). Chile and Israel decided to follow the riskier course of first announcing inflation targets to bring down stubbornly high inflationary expectations. The other emerging market countries either had short transition periods or moved directly to full-fledged inflation targeting in a setting of lower and declining inflation. In addition, the countries that moved to inflation

\section{Table 4.I.Timing of Transitions to Full-Fledged Inflation Targeting by Emerging Market Countries}

\begin{tabular}{|c|c|c|}
\hline & $\begin{array}{l}\text { Beginning of Transition to } \\
\text { Inflation Targeting }\end{array}$ & $\begin{array}{l}\text { Adoption of Full-Fledged } \\
\text { Inflation Targeting }\end{array}$ \\
\hline Brazil & June 19991 & June $1999^{3}$ \\
\hline Chile & Sep. $1990^{2}$ & Sep. 19994 \\
\hline Czech Republic & Dec. 19971 & Dec. $1997^{3}$ \\
\hline Israel & Dec. $1991^{2}$ & June $1997^{4}$ \\
\hline Poland & Oct. $1998^{\prime}$ & Mar: 19994 \\
\hline South Africa & Aug. 19991 & Feb. $2000^{3}$ \\
\hline \multicolumn{3}{|c|}{$\begin{array}{l}\text { Sources: Leone (1999), Landerretche and others (1999), Bernanke and others (1999). Clinton (2000), Leiderman } \\
\text { and Bar-Or (2000), IMF (2000), and central bank websites. }\end{array}$} \\
\hline \multicolumn{3}{|c|}{ 'Official announcement of intention to adopt an inflation targeting framework. } \\
\hline \multicolumn{3}{|c|}{${ }^{2}$ Announcement of first inflation target. } \\
\hline \multicolumn{3}{|c|}{${ }^{3}$ Announcement of details of full-fledged inflation targeting framework. } \\
\hline \multicolumn{3}{|c|}{${ }^{4} \mathrm{Abandonment}$ of exchange rate band or broadening of the band to a range that makes policy conflicts between } \\
\hline
\end{tabular}




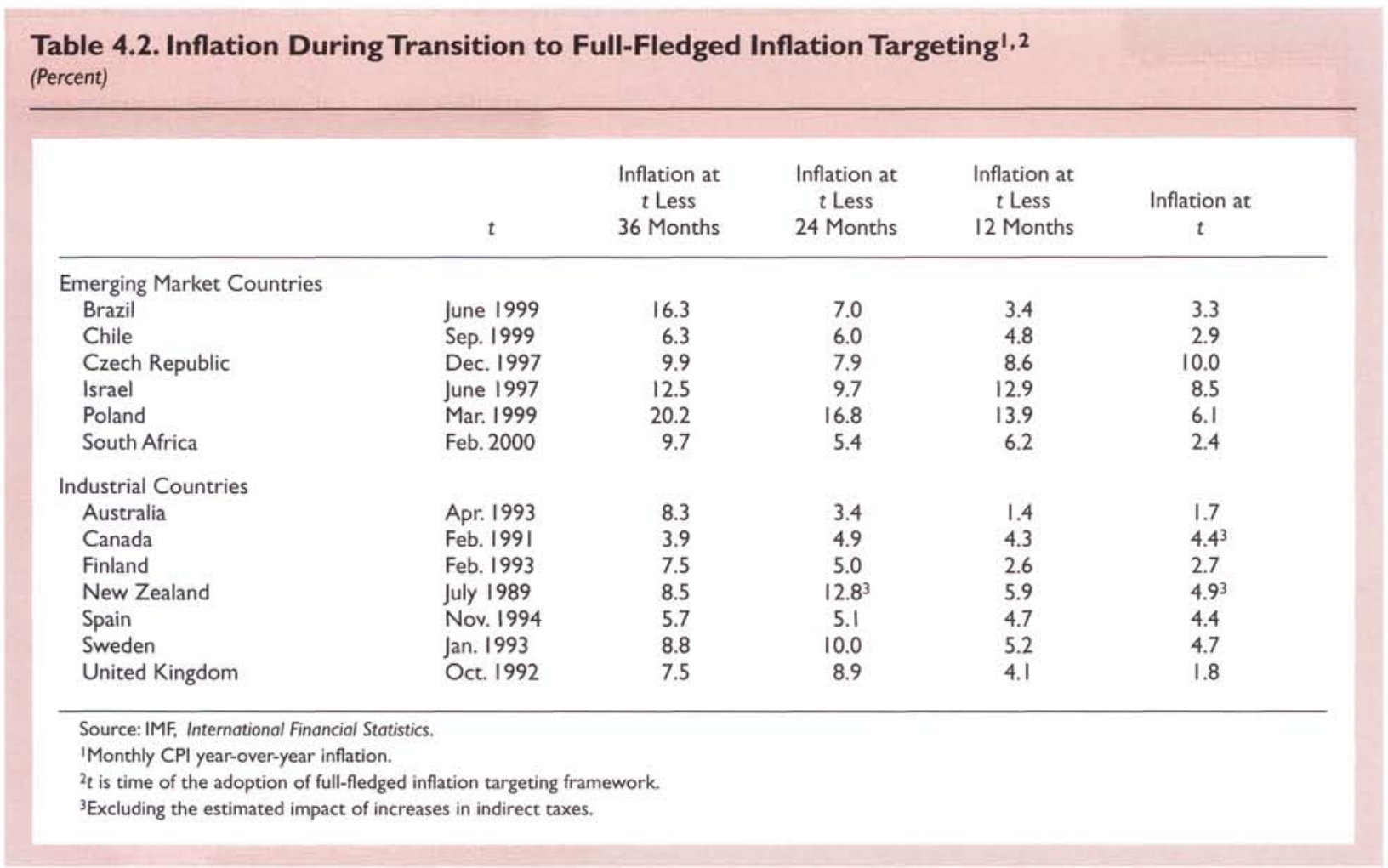
Table 4.3. Inflation Prior to Beginning of Transition to Inflation Targeting'
(Annual average CPI inflation; percent)

\begin{tabular}{lcccccc}
\hline Country & \multicolumn{7}{c}{$\begin{array}{c}\text { Inflation at } \\
\text { Less 4 Years }\end{array}$} & $\begin{array}{c}\text { Inflation at } \\
t \text { Less 3 Years }\end{array}$ & $\begin{array}{c}\text { Inflation at } \\
t \text { Less 2 Years }\end{array}$ & $\begin{array}{c}\text { Inflation at } \\
t \text { Less I Year }\end{array}$ & Inflation at $t$ \\
\hline Brazil & $t$ & 66.0 & 15.8 & 6.9 & 3.2 & 4.9 \\
Chile & 1999 & 20.6 & 19.9 & 14.7 & 17.0 & 26.0 \\
Czech Republic & 1990 & $\ldots$ & 10.1 & 9.1 & 8.8 & 8.4 \\
Israel & 1997 & 19.8 & 16.3 & 20.2 & 17.2 & 19.0 \\
Poland & 1991 & 33.3 & 26.8 & 20.2 & 15.9 & 11.7 \\
South Africa & 1998 & 8.6 & 7.4 & 8.6 & 6.9 & 5.2 \\
\hline
\end{tabular}

Source: IMF, International Financial Statistics.

' $t$ is time of the start of the transition to full-fledged inflation targeting framework.

targeting in the late 1990 s may have benefited from what had already been learned about this framework, whereas Chile and Israel had to "learn by doing."

\section{Disinflation Experiences}

Most countries that started with higher rates of inflation and crawling exchange rate regimes disin- flated over long transition periods to limit disruptions to the real economy. Chile and Israel slowly shifted from a crawling exchange rate regime to an inflation targeting framework. Their experiences are illuminating because they were the first emerging market countries to announce inflation targets and they began their transition to a full-fledged inflation targeting framework when inflation was at doubledigit levels. 
After a decade when inflation fluctuated around 25 percent, Chile began announcing inflation targets in 1990 and adopted full-fledged inflation targeting in 1999. A major reason for the move toward inflation targeting was to bring down stubbornly high inflation expectations by providing the public with an explicit inflation objective (Landerretche and others, 1999). The Chilean central bank relied on a series of annual targets to guide the inflation rate lower in recognition of the high initial inflation rate, potentially large short-term losses in real output, and employment associated with disinflation in the context of widespread indexation of wages and prices, in addition to the risk of triggering turbulence in the foreign exchange markets.

In Israel, inflation targets were introduced in 1991 as an important input into the specification of an upward slope for the crawling exchange rate peg. There was no clear perception at the outset as to the central bank's degree of commitment to achieving the inflation targets; only gradually, over a number of years, did the inflation targets develop a life of their own as the authorities demonstrated that achieving them was the primary objective of monetary policy (Bernanke and others, 1999; Leiderman and Bar-Or, 2000). The length of the disinflation in Israel reflected the limited degree of public support for an active program to reduce inflation to singledigit levels if that program meant incurring real costs in terms of lost output or higher unemployment (Offenbacher, 1996). These costs were potentially significant in Israel given the widespread practice of indexation of prices in local contracts and the country's history of high inflation. Consequently, monetary policy aimed to encourage more forward looking behavior on the part of wage and price-setters and a move away from indexation.

Chile and Israel distinguished between the longrun inflation goal and interim inflation targets. The real costs of disinflation depend importantly on how fast inflation is brought down, the extent of nominal rigidities in the underlying economy, and on the attainment of credibility. By using annual targets to adjust the speed of disinflation and take advantage of unexpected disinflation opportunities, the real costs of reducing inflation could be moderated, and employment and output maximized, while at the same time maintaining a strong commitment to long-run inflation control. The adoption of inflation targeting can lead to mutually reinforcing structural reforms in other areas, especially fiscal consolidation, which reduce the costs of disinflation (Leiderman and Bar-Or, 2000).

The durable success of the disinflation efforts of Chile and Israel are instructive. Their initial rates of inflation were moderate-less than 25 percent. Moreover, disinflation was made easier by lasting improvements in structural and fiscal policies. Trend improvements in productivity followed from structural reforms in both countries as well as immigration for Israel. Government debt was reduced sharply in Chile, and the financial systems in both countries were strong enough to weather the Mexican and Asian crises of the late 1990s.

Inflation targeting frameworks notably have not been used to engineer major disinflation from a starting point of high inflation, however. More experience with inflation targeting-based disinflation will be needed before it can be compared with exchange rate- or money-based approaches, which have been used with mixed success to bring inflation down from high levels relatively quickly (Calvo and Végh, 1999).

\section{Shifting from an Exchange Rate Regime}

Nine of the 13 inflation targeting countries shifted from an exchange rate targeting regime (Table 4.4). Chile and Israel announced their inflation targets in the context of formulating exchange rate target paths. More recently, emerging market countries have adopted inflation targeting rapidly after dropping their previous monetary framework and announcing their commitment to inflation targeting (Brazil, Poland, and South Africa).

The experiences of Chile and Israel may offer some practical lessons on how to minimize the inherent conflicts between exchange rate and price stability for emerging market countries that want to take the slow track approach. Early on, after the announcement of the new inflation targets, the exchange rate could be viewed as entering independently into the objective function of policymakers owing to its importance for the real sector and for exchange rate stability in these open economies. Many of the features of Chile's crawling band (width, rate of crawl, reference currency basket, degree of symmetry, and central parity level) were modified in response to changing policy objectives and market conditions (Landerretche and others, 1999; Ugolini, 1996). Over time, conflicts between the inflation target and the exchange rate band were usually solved in favor of the former. In mid-1995, the declining weight of the exchange rate in Israel was marked by the widening of the crawling band in response to appreciation pressures to 14 percent, to 28 percent in 1997, and then to 40 percent in 1999. Chile also continuously widened its exchange rate band and abandoned it in September 1999.

Both countries judiciously used foreign exchange intervention to keep the exchange rate within the pre-announced crawling band. Intervention by the 
Table 4.4. Exchange Rate Regime Prior to Adoption of Inflation Targeting

\begin{tabular}{ll}
\hline $\begin{array}{l}\text { Emerging Market Countries } \\
\text { Brazil }\end{array}$ & Crawling exchange rate band \\
Chile & Crawling exchange rate band \\
Czech Republic & Crawling exchange rate band supplemented by a monetary \\
guideline and a disinflation objective & Crawling exchange rate band \\
Israel & Crawling exchange rate band \\
Poland & Floating exchange rate with informal inflation targeting and \\
South Africa & announced guidelines for broad money growth \\
Industrial Countries & Floating exchange rate \\
Australia & Floating exchange rate \\
Canada & Exchange rate peg to European Currency Unit (ECU) \\
Finland & Floating exchange rate \\
New Zealand & Exchange rate band within Exchange Rate Mechanism (ERM) \\
Spain & of the European Monetary System \\
Sweden & Exchange rate peg to ECU \\
United Kingdom & Exchange rate band within ERM \\
\hline Sources: IMF, Exchange Arrangements and Exchange Restrictions; central bank websites.
\end{tabular}

Chilean central bank to keep the exchange rate within the band was frequent and intense. Similarly, heavy sterilized foreign exchange intervention was undertaken by the Bank of Israel to keep the Israeli currency (shekel) from appreciating outside its band in response to capital inflows.

\section{Balancing Risks}

The unfavorable economic developments that often motivate the shift to inflation targeting can pose risks for its credibility. Inflation targeting often has been introduced in the wake of exchange rate crises, high inflation, and poor overall economic performance (Table 4.5). In addition, four countries have been motivated by their prospective accession to European Economic and Monetary Union (EMU). Adopting inflation targeting before enough time has passed from the time of the motivating crisis or period of unfavorable economic developments risks a recurrence of these factors, which could compel monetary policy to subordinate the new inflation objective. This risk is especially important for emerging market countries because they are more prone to fiscal imbalances and financial and exchange rate crises (IMF, 1998b).

A strong fiscal position is essential for the successful operation of inflation targeting. Monetization of government debt that could jeopardize the credi- bility of the inflation target is precluded by a sufficiently strong fiscal position (Kumhoff, 2000). A lack of fiscal discipline can also complicate monetary policy by undermining the capacity of the central bank to conduct effective monetary operations with government securities. Moreover, large fiscal imbalances may require the central bank to pursue a tighter-than-desired monetary policy stance to demonstrate its commitment to inflation control. Such a constraint on monetary policy was experienced by the Bank of Canada in the early 1990s, when the high public debt and deficit situation hindered its scope for easing monetary conditions (Clinton and Zelmer, 1997).

The fiscal position of emerging market countries generally strengthened ahead of their transition to inflation targeting, whereas that of industrial countries improved after its adoption. ${ }^{13}$ Net government debt to GDP declined prior to the beginning of the transition to inflation targeting for the emerging market countries, with the notable exception of Brazil. In contrast, for the industrial countries, government debt rose prior to inflation targeting and structural fiscal balances generally worsened. This discrepancy may reflect the need for a stronger sig-

\footnotetext{
${ }^{13} \mathrm{Net}$ government debt and structural fiscal balance data are from the IMF World Economic Outlook database. Structural fiscal balance data are not available for emerging market countries.
} 
is a significant positive bias in the measurement of consumer price inflation and a large degree of downward wage rigidity. This target also reflects the belief that it is important to allow real interest rates to become negative at troughs in the economic cycle. ${ }^{14}$ A lower long-run inflation rate could be appropriate if the measurement bias is small and wages are flexible, but there is a broad consensus that a zero target is too low. Thus, in practice the range of long-run in-

\footnotetext{
${ }^{14}$ See also Fortin (1996) and Summers (1991). However, these studies did not address the possibility that a successful inflation targeting framework may change the expectations formation process. This could, in turn, affect price and wage setting, thereby lowering the long-run inflation rate.
}

flation rates used in industrial countries (i.e., 0 to 3 percent) is not very wide.

Technical uncertainties about the appropriate long-run target rate of inflation might be more acute for an emerging market country than for an industrialized country. Upward bias in the consumer price data can be accentuated by relatively limited data collection and by the importance of quality enhancement (Clinton, 2000). In addition, the more rapid pace of structural change means that less is known about the productivity growth rate and the degree of wage flexibility that underlie the bias. Chile, the Czech Republic, Israel, and Poland have signaled their aim to achieve a long-run inflation rate similar to that of their trading partners. 


\section{Operational Issues}

$\mathbf{T}$ his section summarizes the operational practices of inflation targeting central banks. In most respects, emerging market countries and industrial countries operate monetary policy similarly under inflation targeting. In all cases, countries need to use a good dose of judgment. However, countries with more developed statistical models can rely relatively more on those models than can countries with less developed statistical models, owing to data shortfalls and ongoing structural changes. In addition, emerging market countries must deal with more pronounced economic and financial shocks and less developed financial markets.

In an inflation targeting framework, the modalities of the operation of monetary policy follow from the lag between a policy change and its impact on inflation. These lags have led to the description of monetary policy under inflation targeting as "constrained discretion," which stands in contrast to the "automatic pilot" approach seen to hold under strict exchange rate or monetary aggregate targeting (Bernanke and others, 1999). This extra degree of discretion lends added importance to the operation of monetary policy.

Monetary policy under inflation targeting works as follows:

- The inflation forecast is usually updated on a regular schedule and based on the latest economic data, indicators of market sentiments, model results, and judgment.

- The desired policy stance-in terms of the level of the operating target required to narrow any gap between the inflation forecast and the inflation target, and taking into account the output gap and other factors-is determined using models and judgment.

- Other factors-such as international developments and political events - that could bear on the timing and magnitude of changes in the policy stance are also considered.

- The change in policy stance is announced and the operating target is adjusted to its desired level.

\section{Inflation Forecasting}

Inflation forecasting is especially challenging for emerging market countries. Inflation forecasts play a key role in the conduct of policy under inflation targeting because of the lags between monetary actions and their impact on inflation. Indeed, the inflation forecast can be viewed as the intermediate target of policy (Svensson, 1997; Bogdanski and others, 2000). Emerging market countries rely less on statistical markets to forecast inflation owing to data shortfalls, ongoing structural changes, and their vulnerability to shocks.

Many inflation indicators are common to all inflation targeting countries. An inflation indicator refers to observable data that have been previously shown to provide useful signals regarding future changes in inflation. Indicators include aggregate demand and supply variables, monetary aggregates, interest rate and exchange rate measures, inflation, price measures, and expectations.

Surveys of inflation expectations conducted by the private sector or even by the central bank itself are useful in the inflation targeting regime. Surveys can directly sample market and consumer inflation expectations (New Zealand), or the central bank can summarize surveys of market inflation expectations (United Kingdom). Qualitative surveys of private sector conditions are utilized in Canada and New Zealand. In addition, informal canvassing of market participants by central bank staff can provide useful information.

Yields on government bonds indexed to inflation can be a useful indicator (Price, 1997). Movements in the spread between the yields on indexed and nonindexed bonds have been used by the central banks of Australia, Canada, Israel, New Zealand, and the United Kingdom to gauge the impact of policy changes and other developments on inflation expectations and/or the inflation risk premium. ${ }^{15}$ These data should be used with care, however, because the

${ }^{15}$ South Africa issued its first indexed government bonds in March 2000. 
market for indexed debt is thin and there may be large and variable risk premiums. Moreover, in some countries technical issues, such as tax treatment of returns on indexed debt compared with nominal debt, can complicate the extraction of information on inflation expectations. Expected future inflation rates can also be derived from nominal and real forward interest rates (Söderlind and Svensson, 1997).

For emerging market countries, aggregate demand and supply indicators have greater weight. The greater weight of these indicators reflects the importance of real shocks and the lack of alternative market-based indicators. Supply shocks seem to be especially important for middle-income emerging market countries (Agénor and others, 1999).

Emerging market countries can benefit from the introduction or refinement of inflation indicators. Several central banks have worked with statistical agencies to define core measures of inflation that provide information on trend movements of inflation. Central banks can also identify or develop new inflation indicators based on market conditions.

The structural models used by central banks to forecast inflation have important common elements. These include an open economy demand curve, a Phillips curve, an international asset market equilibrium condition, and a monetary policy reaction function (Bogdanski and others, 2000; Clinton, 2000). These elements have been used extensively in empirical work on central bank behavior, monetary policy rules, and sacrifice ratios (Taylor, 1999). Also, they lie at the heart of some of the new large macroeconometric models developed in central banks, including the Bank of Canada's Quarterly Projections Model (QPM) and the U.S. Federal Reserve Board's FRB/U.S. model.

Large-scale macroeconomic models are used by several industrial countries. These models can serve as useful guides to policy for countries that have had inflation targeting in place for some time and have stable economic relationships. Canada and New Zealand use large dynamic models to produce forecasts (Drew and Hunt, 1998). These models are calibrated to provide theoretically plausible simulation results because the parameters generated by estimation on the basis of a good fit to historical data proved to be less useful for conducting policy simulations. Development of large-scale models has taken many years, notwithstanding the relatively long period of time that inflation targeting has been in place. Most industrial countries also utilize small structural models that capture a particular sector or key variable to assess developments in key sectors (Drew and Hunt, 1998).

Emerging market countries, in contrast, rely less on quantitative models. This is because the years of experience with inflation targeting are too few to generate reliable estimates of such a model, and because of ongoing changes in structural relationships (Leone, 1999; Leiderman and Bar-Or, 2000). However, most emerging market inflation targeting central banks have found it worthwhile to devote extra resources to development of such models for greater future use. Brazil, the Czech Republic, and Israel all work with three or four equation models along the lines of those commonly used by industrial country central banks (Bogdanski and others, 2000; Clinton, 2000).

Models can facilitate monetary policy in important ways other than by producing inflation forecasts (Isard and Laxton, 2000a). Small-scale models can help central banks think through policy transmission channels. More important, models can serve as a framework for policy discussion and can even assist in the presentation of the inflation forecasts that are so essential to transparency. Fan charts, showing the probability distribution of inflation forecasts over a range of outcomes, are a recent improvement in presentation that is facilitated by quantitative models (Allen, 1999).

Time series models impose less economic structure but provide better short-term forecasts, as well as a consistency check for the larger structural models. Univariate models of the aggregate inflation index, components of the index, or other key inflation indicators are relatively easy to produce and allow for frequent assessment of economic conditions. In New Zealand, output from these models is used to provide forecasts for the first two quarters beyond the most recent historical data. Multivariate time series models (e.g., vector autoregression) allow for the simultaneous interaction between time series with few, if any, structural assumptions. Such models are also used by the central banks of Brazil, Chile, and Israel.

In practice, inflation forecasts are based on a combination of indicator variables, quantitative economic models, and qualitative judgment. Inflation targeting central banks typically first analyze the output from their economic models and other assorted inflation indicators, and then apply judgment based on qualitative information gathered from their contacts in all sectors of the economy to arrive at a view regarding the appropriate stance for monetary policy.

\section{Policy Transmission Channels}

The policy channels between changes in the monetary stance and inflation for open economies generally operate through direct and indirect channels (Svensson, 1998; Ball, 1999). In the short run, an increase in interest rates directly reduces inflation by 
appreciating the exchange rate, which passes through into lower imported goods prices. Over the longer term, an increase in interest rates indirectly reduces inflation first by dampening expectations and thereby business investment, and second, by reducing consumption and thereby causing an exchange rate appreciation that switches expenditures from traded to non-traded goods. Of course, the central bank cannot count on the exchange rate to transmit a policy change to a prespecified change in inflation, even if over time the exchange rate has been the main short-run policy channel. The markets will determine whether a given change of policy will influence inflation primarily via the exchange rate or through market interest rates. In addition, monetary policy may influence inflation indirectly by altering wealth and thereby aggregate demand.

Emerging market countries with higher inflation rates seem to have channels characterized by downward price stickiness and rapid pass-through from the exchange rate to inflation (Table 5.1). In Brazil, Chile, and Israel, long experiences with high rates of inflation and indexation often led to downward price inertia and almost contemporaneous pass-through from exchange rate changes to inflation until the inflation targeting framework became credible (Bogdanski and others, 2000; Landerretche and others, 1999; Leiderman and Bar-Or, 2000; Leone, 1999). Exchange rate pass-through seems to be slower for industrial countries - that is, around six to eight quarters (Menon, 1995). For New Zealand, the direct exchange rate channel, which operates in the short term, is seen as having been muted by exchange rate hedging and by a lengthening of the lags between policy and inflation. For Brazil, the indirect channel of monetary policy through demand is seen to take two or three quarters to affect inflation.

Policy channels can be rendered less effective by corporate and bank balance sheet problems and underdeveloped financial markets. Policy channels in the Czech Republic have been stifled by the highly interest inelastic lending policies of banks burdened by nonperforming loans and borrowing practices of unprofitable enterprises. In Poland, the credit channels of policy have been weakened by undeveloped financial markets and strong capital inflows.

\section{Policy Implementation}

All inflation targeting countries use a very shortterm interest rate as the operating target. The operating target can be defined as the money market indicator that best captures the authorities' intentions (Table 5.2). The popularity of an overnight interest rate operating target implies that central banks have chosen to broadly accommodate fluctuations in the demand for bank reserves or settlement balances. The growing popularity of short-term interest rates as an operating target is part of the larger trend away from money stock targets (Borio, 1997; Van't dack, 1999) and need not be inherent to the inflation targeting framework.

Some open economy central banks have used an average of an interest rate and the exchange rate (a monetary conditions index) as an operating target or as a way to facilitate the signaling of policy intentions. Monetary conditions indices (MCI) have been used because in a small open economy it can be difficult to predict whether a policy adjustment will influence aggregate demand and inflation through the exchange rate or interest rates. The monetary conditions index is a weighted combination of the exchange rate and short-term interest rate less their values in a base period and can be calculated in nominal or real terms. The weights are determined by the relative influence of the exchange rate and benchmark interest rate for real aggregate demand. In practice, the usefulness of the monetary conditions index as a means of publicly communicating the central bank's monetary policy stance has been complicated by the expectation by some market players that all exchange rate shocks (even on a daily frequency) might be offset by interest rate adjustments to keep the index fixed, and by the fact that different types of exchange rate shocks can have different implications for the desired path of the index (Freedman, 1994; Hunt, 1999). Canada was the first to use such an index in the late 1980 s, but reduced its role as a signaling device in the spring of 1998. New Zealand reported a projected path and band width of a monetary conditions index, but shifted to an interest rate operating target in mid1998 to smooth interest rate volatility, which was complicating communication of the desired policy stance.

All of the inflation targeting central banks employ market-based instruments of monetary policy to maintain the operating target interest rate at the desired level. Open market operations (OMOs), conducted on an outright or repo basis, are the prevalent monetary instrument for central banks that operate under the inflation targeting framework (Table 5.2). Most central banks use open market operations to maintain domestic liquidity conditions in line with the announced operating interest rate. These open market operations take the form of central bank purchases and sales of Treasury or central bank securities, usually with a commercial bank counterparty.

Inflation targeting central banks appear to rarely use direct instruments for active liquidity management, if at all. Direct instruments of monetary policy, such as reserve requirements, loan limits, and liquidity asset ratio requirements, can only be ad- 
Table 5.I. Important Features of Monetary Policy Transmission Channels

\begin{tabular}{|c|c|}
\hline & Important Features \\
\hline \multicolumn{2}{|c|}{ Emerging Market Countries } \\
\hline Brazil & $\begin{array}{l}\text { Interest rate affects inflation with minimum lag of six months with } \\
\text { rapid exchange rate pass-through. }\end{array}$ \\
\hline Chile & $\begin{array}{l}\text { Indexation has led to downward price inertia and quick } \\
\text { transmission (approximately three quarters) from exchange rate } \\
\text { and wage shocks to inflation. }\end{array}$ \\
\hline Czech Republic & $\begin{array}{l}\text { The transmission mechanism has been weakened by the fragility of } \\
\text { the financial sector. }\end{array}$ \\
\hline Israel & $\begin{array}{l}\text { Widespread indexation has led to relatively quick pass-through } \\
\text { from exchange rate to prices. More recently, pass-through has } \\
\text { lengthened. }\end{array}$ \\
\hline Poland & $\begin{array}{l}\text { Credit channel is weak due to the structure of the banking sector } \\
\text { and the relatively undeveloped financial markets. }\end{array}$ \\
\hline South Africa & $\begin{array}{l}\text { Interest rate changes affect inflation with a lag and linkages } \\
\text { between broad money and inflation are weak. }\end{array}$ \\
\hline \multicolumn{2}{|l|}{ Industrial Countries } \\
\hline Canada & $\begin{array}{l}\text { The transmission mechanism is well developed; lags typically range } \\
\text { from six to eight quarters, but they have varied somewhat over } \\
\text { time. }\end{array}$ \\
\hline Finland & $\begin{array}{l}\text { The move to flexible exchange rates has weakened the } \\
\text { transmission mechanism and has increased exchange rate } \\
\text { variability. }\end{array}$ \\
\hline New Zealand & $\begin{array}{l}\text { The transmission mechanism is well developed; lags typically range } \\
\text { from six to eight quarters, but they have varied somewhat over } \\
\text { time. }\end{array}$ \\
\hline Spain & $\begin{array}{l}\text { Variables in the real exchange rate appear to be the most } \\
\text { important of the monetary transmission channels. }\end{array}$ \\
\hline Sweden & $\begin{array}{l}\text { The transmission mechanism is well developed; lags typically range } \\
\text { from five to eight quarters. }\end{array}$ \\
\hline United Kingdom & $\begin{array}{l}\text { Monetary policy has its maximum effect on output after around a } \\
\text { year, and on inflation after around two years. }\end{array}$ \\
\hline
\end{tabular}

Sources: Andrés and others (1998), Borio (1997), Corbo (2000), de Fiore (1998), Haldane (2000), Leone (1999). Landerretche and others (1999), Leiderman and Bar-Or (2000), Jonsson (1999), Van't dack (1999).

justed infrequently. This aspect of direct instruments implies that they may not be effective in offsetting inflationary shocks and in signaling the policy intentions of the central bank. In contrast, market-based instruments can be adjusted quickly in response to inflationary shocks, and are more easily fine-tuned to achieve the desired policy stance and signal changes in the policy outlook (Alexander and others, 1995). These considerations suggest that market-based instruments are extremely useful for implementing monetary policy under inflation targeting.

Most inflation targeting countries adjust shortterm interest rates in response to deviations of inflation or expected inflation from the target and the output gap. In general, central bank interest rate setting behavior has been characterized in many studies as a Taylor rule under which interest rates are adjusted in response to deviations of current and lagged variables such as inflation and the output gap (Borio, 1997; Taylor, 1999). Under inflation targeting, interest rate response functions are more forward-looking than under other policy frameworks, owing to the lags between policy changes and the inflation outcome and the desire to avoid excessive output volatility (Isard and others, 2000; Armour and Côté, 2000). In Brazil, the central bank employs three interest rate response functions in its model simulations: an exogenous interest rate path, a Taylor rule with linear combination of system variables, and interest rate paths generated by optimal response functions.

In practice, central banks complement such an approach with judgment that uses all information per- 
Table 5.2. Operating Targets and Main Instruments of Monetary Policy

\begin{tabular}{|c|c|c|}
\hline & Operating Target & Main Instruments \\
\hline \multicolumn{3}{|c|}{ Emerging Market Countries } \\
\hline Brazil & Overnight interbank interest rate (SELIC) & $\begin{array}{l}\text { Open market operations (OMOs) using Treasury } \\
\text { bonds or bonds issued by the central bank }\end{array}$ \\
\hline Chile & $\begin{array}{l}\text { Real overnight interbank rate tied to CPI } \\
\text { with } 20 \text {-day lag }\end{array}$ & $\begin{array}{l}\text { OMOs through issuance of central bank paper and } \\
\text { repurchase agreements (repos) }\end{array}$ \\
\hline Czech Republic & Two-week repo rate & Daily two-week repo auctions \\
\hline Israel & $\begin{array}{l}\text { Interest rate on short-term loans to and } \\
\text { deposits with banks }\end{array}$ & $\begin{array}{l}\text { Fixed-term and daily discount-window loans to banks, } \\
\text { and OMOs with Treasury bills }\end{array}$ \\
\hline Poland & 28-day National Bank of Poland bill rate & OMOs with central bank bills \\
\hline South Africa & Overnight repo rate & OMOs with government securities \\
\hline \multicolumn{3}{|l|}{ Industrial Countries } \\
\hline Australia & Overnight interest rate & $\begin{array}{l}\text { OMOs with repos and outright transactions in } \\
\text { government securities }\end{array}$ \\
\hline Canada & Overnight interest rate & Operating band enforced through standing facilities \\
\hline Finland & Monthly repos and outright OMOs & OMOs with government securities \\
\hline New Zealand & Overnight cash rate & $\begin{array}{l}\text { Lending or borrowing of overnight money to } \\
\text { commercial banks }\end{array}$ \\
\hline Spain & Money market overnight interest rate & $\begin{array}{l}\text { OMOs with government securities and central bank } \\
\text { paper }\end{array}$ \\
\hline Sweden & Weekly repo rate & OMOs with central bank paper \\
\hline United Kingdom & Short-term repo interest rate & $\begin{array}{l}\text { OMOs with repos, government securities, and other } \\
\text { eligible local authority and bank bills }\end{array}$ \\
\hline
\end{tabular}

Sources: Central bank websites, Borio (1997), Van't dack (1999), and Landerretche and others (1999).

taining to the inflation forecast. Emerging market central banks often must use more judgment because their models are subject to uncertainties. Information on many variables is available only with a lag and could be subject to revision (Orphanides, 1998). Shocks may be larger and more persistent than for industrial countries (Agénor and others, 1999), and their models are subject to parameter instability (Brainard, 1967).

\section{Inflation Targeting and IMF Conditionality}

The prospect that countries with IMF-supported programs may adopt inflation targeting has prompted a reconsideration of monetary policy conditionality in those countries. The traditional monetary policy conditions for IMF programs are a floor on the central bank's net international reserves (NIR) and a ceiling on the central bank's net domestic assets (NDA), or in some cases on base money (Schadler and others, 1995). Under flexible exchange rates, a floor on net international reserves serves to limit foreign exchange market interven- tion, while a ceiling on net domestic assets or base money is intended both as a check against either the sterilization of foreign exchange market intervention or excessive monetary expansion that would jeopardize price stability. Given the uncertainty that characterizes all econometric relationships, a breach of the net international reserves floor or the net domestic assets ceiling does not necessarily signal an overexpansionary monetary policy stance; instead, it is a signal that the monetary policy stance may need to be reassessed. Such a reassessment-in the context of considering a waiver for a breach of a performance criterionmust take account of the full range of factors that are relevant to achieving the program's objective (Mussa and Savastano, 1999).

If the traditional configuration of performance criteria is used in a country following inflation targeting, it is important to distinguish between the conduct of monetary policy and program monitoring. Central banks typically steer a short-term interest rate as the operating target rather than net domestic assets and pay attention to a range of inflation indicators for their monetary policy decisions. The floor on net international reserves and the ceiling on net 
domestic assets provide a check that these do not conflict with program objectives. But given the greater transparency associated with inflation targeting, together with the IMF's increasing transparency, there is a risk of confusion between the inflation objective that guides monetary policy and the traditional performance criteria used to monitor the IMFsupported program.

The IMF has, on an experimental basis, adopted a reviews-based approach to monetary conditionality under inflation targeting as an alternative to the traditional configuration of performance criteria. Under this approach, monetary policy would be subject to quarterly reviews focusing on indicators of inflation prospects, including recent inflation outturns and various leading indicators of inflation. A floor for net international reserves would also be retained under this approach to limit the use of the IMF's resources for foreign exchange market intervention.

A variant of the reviews-based approach is currently in use in Brazil, the only inflation targeting country supported by an IMF arrangement. A "consultation mechanism for inflation" is included as a condition for monetary policy, as well as a floor on net international reserves and an indicative ceiling on net domestic assets (Blejer and others, 2000). Based on the government's announced annual inflation targets, quarterly bands of \pm 1 percentage point for the inner band and \pm 2 percentage points for the outer band have been established. Should the inflation rate exceed the upper limit of the inner band, the central bank will discuss the appropriate policy response with the IMF. In case of a breach of the upper limit of the outer band, the authorities will complete consultation with the IMF's Executive Board on the proposed policy response before requesting further financing under the program.

\section{Changing Economic Relationships}

Structural changes seem minor in the early stages of inflation targeting, but as the framework gains credibility, empirical evidence suggests that the linkages between inflation and the level of economic activity weaken. The experiences of both emerging market and industrial inflation targeting countries suggest that a new inflation targeting framework gains credibility gradually as the central bank demonstrates its ability to achieve the targets (Johnson, 1998). Moreover, the results of Bernanke and others (1999), Fillion and Léonard (1997), Landerretche and others (1999), and Leiderman and Bar-Or (2000) indicate that inflation becomes less responsive to the level of economic output and the exchange rate following the introduction of the targets. ${ }^{16}$ This also suggests that while expectations may respond quickly in a high-inflation environment to monetary policy changes, the transmission channels appear to become more complex and indirect when inflation is low. Similar conclusions can also be drawn for the relationship between monetary aggregates and inflation.

As the links between inflation and output weaken, the central bank may want to take an "eclectic" approach to formulating its outlook for inflation, and in deciding on appropriate monetary actions. Such an approach may help uncover, through experience, the rules of thumb appropriate for the inflation targeting framework (Bertocchi and Spagat, 1993). This suggests that following the establishment of credibility it might be prudent to monitor a broad range of indicators of inflation with the aim of looking for consistent signals across indicators. This would be particularly relevant in periods when the economy is operating near potential and authorities cannot place much confidence in traditional measures of the output gap to guide monetary policy.

The growing credibility of the inflation targeting framework also appears to be associated with a weaker relationship between the exchange rate and inflation. Domestic prices and inflation expectations are now less sensitive to exchange rate movements in Chile, for example, which has contributed to longer lags in its monetary policy transmission mechanism.

\section{Breaches of the Inflation Target}

Communicating ahead of time on how the central bank will respond to breaches of the target may reduce uncertainty. Clifton (1999) argues that inflation targeting central banks must communicate in advance how they will treat the boundary points in order to minimize uncertainty with respect to the conduct of monetary policy and contribute to the credibility and transparency of the monetary policy framework.

\section{Target Floor}

Central banks have eased monetary policy in response to bottom breaches only after it has become clear that the banks' outlook for future inflation was

\footnotetext{
${ }^{16}$ Bernanke and others (1999) note that the shifts in economic relationships were not unique to inflation targeting countries; they were also evident in major non-inflation targeting countries, notably the United States. The adoption of inflation targeting frameworks possibly enabled countries to participate in the credibility gains enjoyed by other countries, however.
} 
Table 5.3. Quarterly Breaches of Inflation Targets

\begin{tabular}{|c|c|c|c|c|}
\hline & \multicolumn{2}{|c|}{ Disinflation Period } & \multicolumn{2}{|c|}{ Long-Run Target Period } \\
\hline & Above Target & Below Target & Above Target & Below Target \\
\hline & \multicolumn{4}{|c|}{ (Number of Quarters) } \\
\hline \multicolumn{5}{|c|}{ Industrial Countries' } \\
\hline Australia & $\ldots$ & $\ldots$ & 0 & 0 \\
\hline Canada & 0 & 8 & 0 & 0 \\
\hline Finland & $\ldots$ & $\ldots$ & 0 & 0 \\
\hline New Zealand & 0 & 4 & 5 & 0 \\
\hline Spain & 0 & 0 & 0 & 0 \\
\hline Sweden & $\ldots$ & $\ldots$ & 0 & 12 \\
\hline \multicolumn{5}{|l|}{ Emerging Markets } \\
\hline Brazil & 0 & 0 & $\ldots$ & ... \\
\hline Chile & 0 & 0 & ... & $\ldots$ \\
\hline Czech Republic & 2 & 4 & $\ldots$ & $\ldots$ \\
\hline Israel & 4 & 2 & $\ldots$ & $\ldots$ \\
\hline Poland & 2 & 0 & $\ldots$ & $\ldots$ \\
\hline
\end{tabular}

Sources: Central bank inflation reports; Bernanke and others (1999).

'Excludes the United Kingdom, which operates with a point target.

signaling that inflation would stay below target. In Sweden, central bank officials were surprised in the latter half of 1996 and early 1997 by the extent of disinflationary pressures prevailing in the economy. These were mainly attributed to the one-time effect of a reduction in value-added taxes, and to declining mortgage rates that were judged as not lowering underlying inflation expectations. It became evident that future inflation would move below the target range, however (Bernanke and others, 1999). The authorities did not wish to risk engaging in instrument instability for the sake of formally hitting a target. Instead, they placed more emphasis in public communications on trends in "core" inflation rates and their own internal forecasts of inflation, even though the targets were defined in terms of the headline consumer price inflation rate.

A consensus seems to exist in favor of symmetric responses to breaches of the floor and ceiling of the inflation target range that arise from demand shocks in order to limit variability in employment and output. Given that deflation can persist, breaches of the floor warrant a decisive response to prevent costly employment and output losses. Equally, breaches of the ceiling require a strong response to maintain credibility, especially for emerging market countries. Moreover, given the lags between monetary policy actions and their effects on inflation, central banks should not-and typically do not-wait for breaches to occur before taking action. Rather, acting once it becomes clear that a breach is likely may help keep the number of actual breaches to a minimum, with consequent payoffs to the credibility of monetary policy.

Countries that are disinflating have been prepared to accept an inflation outcome below the tolerance zone, however. Table 5.3 and Figures 5.1 and 5.2 summarize the number of occasions inflation targeting central banks have seen inflation move away from the target in the period where the inflation targets were interim targets on a path to a long-run inflation objective. Canada, the Czech Republic, Israel, and New Zealand did not hesitate to take advantage of unexpected opportunities to lock-in disinflationary outcomes - either by allowing inflation to undershoot until the target range caught up to the decline in the inflation rate (Canada and New Zealand), or by ratifying the decline in the inflation rate with lower interim targets (Israel). The four countries seized these opportunities to achieve the long-run inflation objective more quickly than originally anticipated-that is, they were "opportunistic disinflators." In a disinflationary phase, such an approach can be a useful means of building credibility for the new inflation targeting framework because "over-achievement" of the interim targets can signal the central bank's determination to bring inflation under control.

Other disinflating countries have treated breaches symmetrically. The Bank of Israel opted in early 1999 to partially reverse the post-Russia crisis tightening of its policy stance to limit uncertainties regarding the objectives of policy, and offset short-run losses in employment and real output. Following the 
Figure 5.I. Industrial Countries: Annual Inflation Rates and Inflation Targets (In percent)

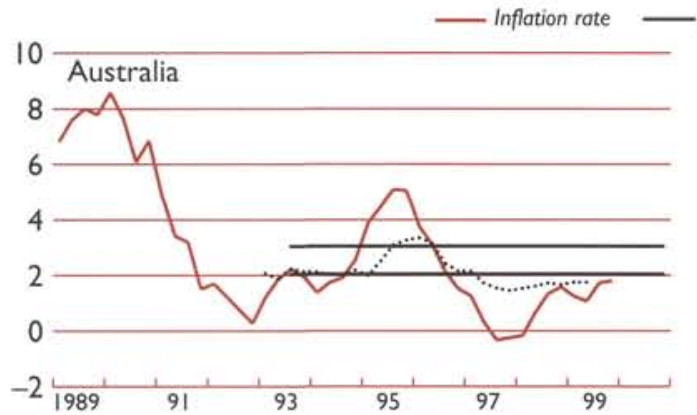

Inflation target rate $\ldots . . . .$. Core $\mathrm{CPI}$
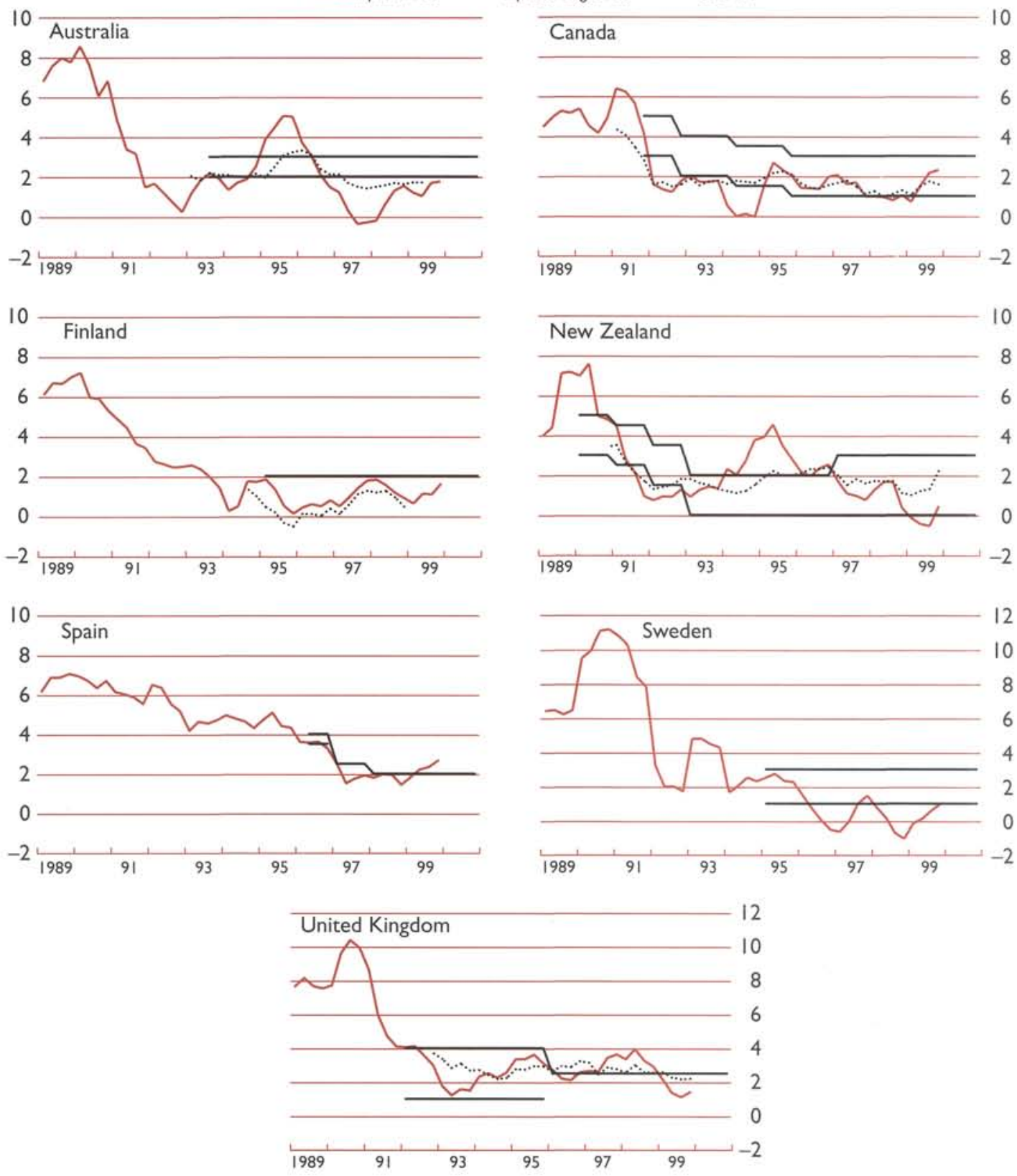

Sources: IMF, International Financial Statistics; national authorities.

cuts, however, the discount rate was still high by both Israeli historical and international standardsat 12 percent in April 1999 - and the inflation target for 1999 was significantly undershot.

\section{Breaches of the Target Ceiling}

Breaches of the target ceiling may not seriously damage the inflation targeting framework provided 
Figure 5.2. Emerging Market Countries: Annual Inflation Rates and Inflation Targets' (In percent)
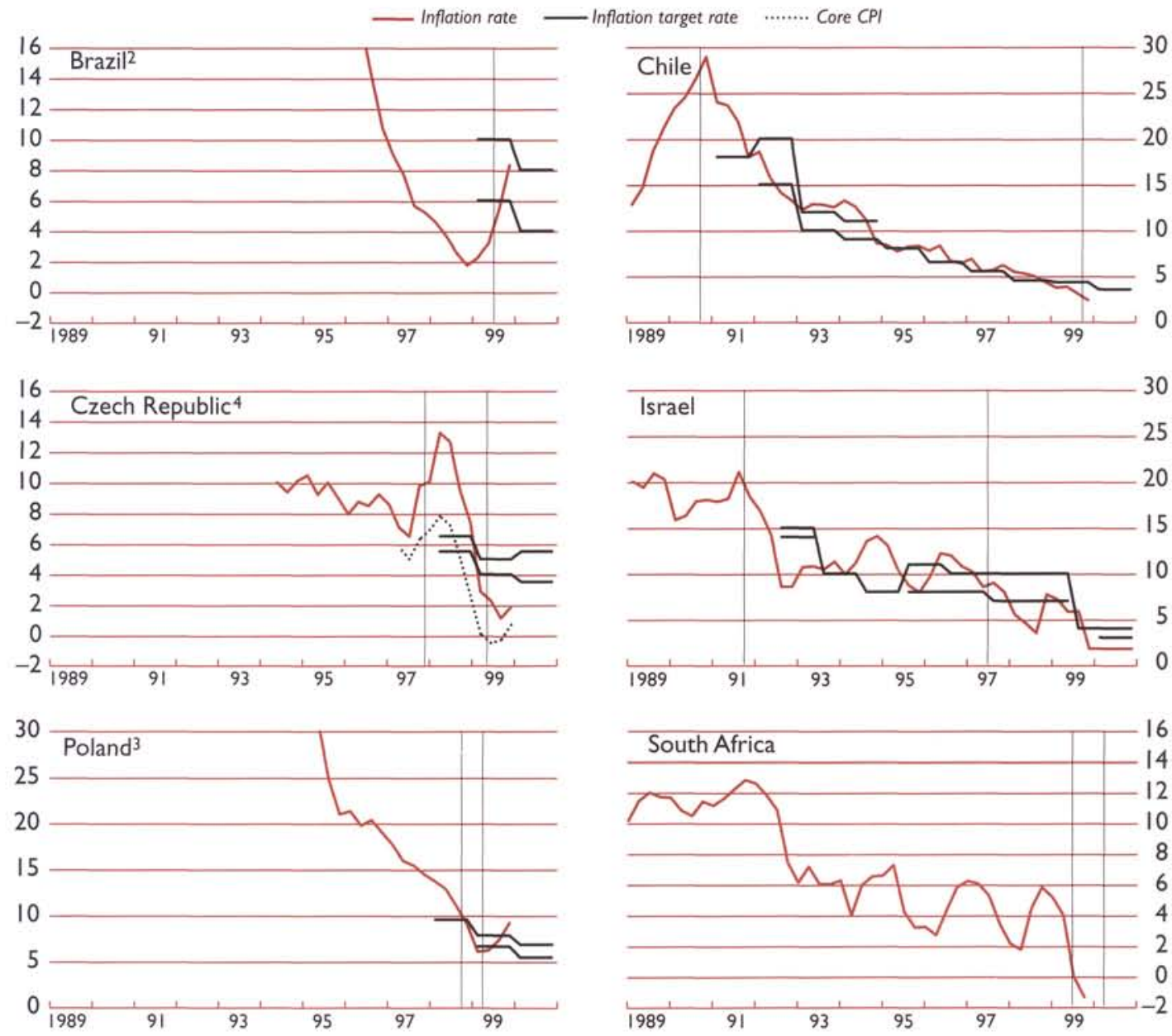

Sources: IMF, International Financial Statistics; national authorities.

IVertical lines indicate start date and end date of transition periods toward adoption of full-fledged inflation targeting framework (see Table 4.I of text).

2During the first half of the $1990 \mathrm{~s}$, inflation peaked at 6,038 percent in the second quarter of 1990

3During the early 1990s, inflation peaked at 1.135 percent in the first quarter of 1990.

${ }^{4}$ During the first half of the $1990 \mathrm{~s}$, inflation peaked at 425 percent in 1991.

transparency and a firm policy response maintain the public's confidence. Inflation moved above the target range in New Zealand in the mid-1990s when the Reserve Bank of New Zealand underestimated the strength of the economy and the associated inflation pressures (Bernanke and others, 1999). The Reserve Bank responded with a significant tightening of its policy stance, resulting in sharply higher interest rates and a major firming of the exchange rate. Several years of higher interest rates followed, as the au- thorities fought to keep the inflation rate within the target range.

In Israel, inflation overshot the 8 percent target in 1994 when the economy performed more strongly than had originally been expected. Inflation expectations did not rise because authorities had already begun to tighten the stance of monetary policy, however-although the exchange rate was in line with the central tendency of the crawling peg when it became clear that achievement of the target was at risk. 
Indeed, this episode was useful because it helped cement the inflation target as the primary objective for monetary policy.

In Poland, inflation moved above the target range in the second half of 1999. Here, too, the central bank misjudged the extent of inflationary pressures present in the economy and conceded in its December 1999 inflation report that policy had been too loose. The bank raised its official interest rate by 100 basis points in September 1999 and again by 250 basis points in November 1999, after the bank's inflation outlook signaled that a target breach was imminent. The yield curve shifted somewhat higher but remained inverted. The target breach did not appear to raise inflation expectations significantly, possibly because the central bank announced ahead of time that a breach was imminent and it clearly demonstrated its resolve to take the actions needed to address the situation.

Conducting monetary policy transparently and acting promptly in a preemptive manner may prevent potential breaches from ratcheting up inflation expectations. None of the observed breaches of the inflation targets significantly undermined the credibility of the inflation targeting frameworks. In part, this may reflect the transparent nature of the frameworks, which provide the public with a firm understanding of monetary policy objectives and the motivations behind the stances adopted by central banks. Moreover, in some cases (Canada and Poland), the central banks went so far as to publicly signal potential breaches of the targets in advance and acted promptly, when required, to forestall the breach. For example, in May 1995 the Bank of Canada publicly signaled in its Monetary Policy Report that an uptick in the inflation rate brought about by one-off exchange rate pass-through effects on the price level would soon be reversed. This helped to ensure that expectations did not become unhinged as the inflation rate rose above the midpoint of the target range. The fact that the bank's projection proved correct may have contributed to the market's subsequent willingness to accept easier monetary conditions (Clinton and Zelmer, 1997). The ability of an inflation targeting framework to absorb unexpectedly high inflation outcomes in a buoyant economic environment has not been fully tested, however.

\section{Responding to Significant Economic and Financial Shocks}

Emerging market countries are inherently more vulnerable to shocks owing to their more concentrated production base, greater openness (in most cases), less developed financial systems, and often less-entrenched policy credibility. Perhaps most important are large shifts in international capital flows that trigger rapid movements in the exchange rate, especially for countries still building credibility of the inflation targeting framework, and pronounced swings in the spreads between domestic and international interest rates. As a result, central banks in emerging market countries tend to rely on qualitative information obtained from their contacts with market participants and the private sector generally and on information from market indicators-for instance, spreads between nominal and real return bonds - when available.

Clear explanations by the central bank of the rationale underlying its policy stance may help nudge expectations in its favor. In situations where the central bank and the market disagree over the appropriate course of monetary policy, the central bank might find it advantageous to communicate the economic rationale underlying its desired policy stance and be clear about the way in which policy is implemented (Zelmer, 1996). Over time, even though a successful inflation targeting framework is unlikely to reduce the possibility of shocks, a proven track record of attaining the inflation targets should help market participants develop greater confidence in the motivations underpinning monetary actions.

\section{Exchange Rate Movements}

Central banks aim to ensure that exchange rate movements do not destabilize inflation expectations or domestic financial markets. The practical difficulty is identifying the cause of the exchange rate movement, which determines whether a policy response is warranted (e.g., in the case of a temporary external shock) or not (e.g., a permanent improvement in domestic productivity).

Many inflation targeting countries responded to exchange rate fluctuations triggered by the 1997-98 Asian/Russian financial crises. The central banks of Canada, Chile, Israel, and New Zealand raised official interest rates, in part because of a concern that the currency depreciation might feed through into domestic inflation expectations (Table 5.4). Chile and Israel, moreover, raised interest rates to accommodate higher risk premiums in the context of their exchange rate bands. This concern is especially important for emerging market countries with large and rapid pass-through effects from exchange rate movements to prices and inflation expectations. In New Zealand's case, the central bank's willingness to tolerate higher interest rates may have also been motivated by its focus on its monetary conditions index and the time taken to fully understand the consequences of the Asian shock for the New Zealand economy. 
Table 5.4.The Policy Response of Inflation Targeters to the Asian/Russian Crises

\begin{tabular}{|c|c|c|c|c|c|}
\hline \multirow[b]{2}{*}{ Inflation Targeting Countries } & \multicolumn{2}{|c|}{ Impact of Crises } & \multicolumn{3}{|c|}{ Response of Monetary Authorities } \\
\hline & $\begin{array}{c}\text { Rapid Exchange } \\
\text { Rate } \\
\text { Depreciation }\end{array}$ & $\begin{array}{l}\text { Higher Medium- } \\
\text { and Long-Term } \\
\text { Interest } \\
\text { Rate Spreads }\end{array}$ & None & $\begin{array}{c}\text { Foreign } \\
\text { Exchange } \\
\text { Intervention }\end{array}$ & $\begin{array}{l}\text { Increase in } \\
\text { Official } \\
\text { Interest } \\
\text { Rates }\end{array}$ \\
\hline \multicolumn{6}{|l|}{ Emerging Markets } \\
\hline Chile & Yes & Yes & & $\mathrm{x}$ & $x$ \\
\hline Czech Republic & No & No & & & $x$ \\
\hline Israel & Yes & Yes & & & $x$ \\
\hline \multicolumn{6}{|l|}{ Industrial Countries } \\
\hline Australia & Yes & Yes & & $x$ & \\
\hline Canada & Yes & Yes & & $x$ & $\mathrm{x}$ \\
\hline Finland & No & No & $x$ & & \\
\hline New Zealand & Yes & Yes & & & $x$ \\
\hline Spain & No & No & $\mathrm{x}$ & & \\
\hline Sweden & No & No & $x$ & & \\
\hline United Kingdom & No & No & $x$ & & \\
\hline
\end{tabular}

Sources: Central bank inflation reports and Bank for International Settlements, Annual Report, 1999.

Domestic financial market stability is another rationale for limiting exchange rate movements prompted by volatile capital flows. The Czech National Bank noted in its inflation report that it adopted a cautious approach toward easing its monetary policy stance in 1998, partly because of concerns that events in Russia might otherwise spill over into its domestic markets. Similarly, the central banks of Canada, Chile, and Israel report that they were forced to raise interest rates aggressively in the latter half of 1998 when turbulence in the foreign exchange market unsettled local fixed-income markets. These central bank actions were meant to contain risk premiums in domestic medium and longer-term interest rates that were rising as investors (domestic and foreign) sought protection against possible losses from any further unexpected exchange rate depreciation. Tactical maneuvers like these are undertaken not necessarily because a tighter monetary stance is desired, but to avoid the more dramatic tightening that might otherwise occur if market expectations were to become destabilizing (Murray and others, 2000).

Financial fragility might limit the scope for allowing exchange rate movements. Central banks may want to moderate exchange rate movements if there is a risk that they could undermine weak balance sheets in the private sector-by triggering losses at banks and nonfinancial corporations with large open foreign exchange exposures (Lane and others, 1999; Stone, 2000). For example, in the case of highly leveraged balance sheets, monetary policy aimed at exchange rate stabilization must account for the negative impact on growth of bankruptcies. Trade-offs between cur- rency stability and growth will depend on the extent of leverage and the split between domestic and foreign debt. Exchange stabilization is especially difficult if foreign currency or dollarized claims make up a large share of balance sheets (Mishkin, 2000).

\section{Tactics for Coping with Shocks}

Options in response to a shock have ranged from doing nothing to a mixture of foreign exchange intervention and tighter monetary policy. Finland, Spain, Sweden, and the United Kingdom were able to come through the shock period associated with the Asian and Russian financial crises without having to respond, since they were buffered to some extent by the capital flows into Europe in the period leading up to the introduction of Economic and Monetary Union. Australia, Canada, and Chile initially engaged in sterilized foreign exchange intervention to moderate the pace of exchange rate depreciation on the grounds that an increase in official interest rates was not warranted given the outlook for inflation domestically. Canada and Chile resorted to increases in official interest rates, however, when it became clear that foreign exchange intervention alone would not be sufficient to restore a sense of two-way risk in the foreign exchange market. Chile also relaxed restrictions on foreign capital inflows (BIS, 1999). Israel and New Zealand accepted higher interest rates without engaging in foreign exchange intervention. The Bank of Israel noted its reluctance to engage in such intervention because of concerns that it might encourage market participants to speculate against the central 
bank. Moreover, by not intervening, the bank hoped to build public awareness of exchange rate risk and encourage the private sector to properly hedge this risk so that the latter would be better positioned to cope with shocks in the future. The Czech Republic adopted a more gradual reduction in official interest rates than it would have chosen based exclusively on the inflation outlook.

Tactical responses to financial market shocks may cause inflation to move below the target. In the cases of the Czech Republic and Israel, a cautious approach to monetary easing (Czech Republic) during the Asian and Russian financial crises and large increases in interest rates that were only gradually unwound (Israel) were followed by a sharp fall in the inflation rate to levels below the target in the subsequent six-month period (see the mid-1999 inflation reports for those countries).

Exchange and capital controls were not used to cope with these shocks. Although such controls can help buy a limited amount of time in the short run to introduce appropriate policies, over the longer run they are less effective than sound macroeconomic policies and a strong well-supervised financial sector (IMF, 1999b).

\section{Coping with Asset Price Bubbles}

Inflation targeting central banks generally only look at asset prices and associated capital flows to the extent that they might affect inflation. The dominant view is that monetary policy should focus on inflation in the markets for goods and services; asset prices are taken into account only insofar as they might affect inflation-for example, through wealth effects on demand (Kent and Lowe, 1998). Nonetheless, some central banks have expressed concerns about "irrational" asset price bubbles, since a sharp reversal of these prices might, in some cases, undermine the stability of the financial system if there is a built-in reliance on the continuation of favorable price trends in asset markets. The prevailing view, however, is not to focus on asset prices directly in the conduct of monetary policy, but rather to take steps to insulate the financial system from the deleterious effects of asset price volatility. Nonetheless, given the shallowness of financial markets in emerging market countries, central banks might be more inclined to take a more protective stance toward sudden, rapid declines in asset prices even if it means that inflation moves outside the target range. ${ }^{17,18}$

\footnotetext{
${ }^{17}$ The key, however, would be to keep the duration of such actions to a minimum so as to limit the amount of time that inflation is outside the target range.

${ }^{18}$ To date, central banks that target inflation in emerging market countries have not been confronted by this issue to any significant extent.
} 


\section{Organizational Implications for Central Banks}

$\mathbf{T}$ his section summarizes how central banks have organized themselves following the introduction of inflation targeting. Successful inflation targeting requires that central banks undertake extensive analysis and forecasting, operate transparently, and be accountable for their actions. Partly, in response, central banks have improved their internal decision making, introduced a broader range of perspectives into the decision-making process, and reallocated resources. However, most of these changes have also been introduced by non-inflation targeting central banks. Thus, the changes are also motivated by broader trends in central bank management.

\section{Internal Decision Making}

Important changes in the internal decision-making processes of central banks have followed the adoption of inflation targeting. Thiessen (1998) argues that this improvement can be largely attributed to the focus on a clear objective-achievement of the mandated inflation targets - and the consequent need to develop a robust framework that maximizes the likelihood of realizing that objective in light of the long lags between monetary policy and their effects on inflation. In particular, the need to explain and justify target breaches is thought to result in a better focused debate within the central bank on the appropriate policy actions to take, and to reduce the likelihood that such decisions will be postponed.

The centrality of inflation forecasts in the operation of policy represents a major challenge for emerging market central banks that target inflation. Emerging market central banks have shifted from controls and regulations to focus more on policy formulation. Moreover, while many emerging market central banks may already have experience in model building, their staff may lack "hands-on" experience in forward-looking models of inflation and in assessing judgmentally the outlook for inflation and the appropriate monetary policy response in an inflation targeting framework.

Developing judgment can be fostered by involving people with a diversity of backgrounds in the de- cision-making process. While not a prerequisite for inflation targeting, in a number of countries the governance structures of inflation targeting central banks have been redesigned to allow for the direct participation of non-career central bankers in the monetary policy decision-making process on either a full or part-time capacity (Table 6.1). Although this trend is not necessarily linked directly to the adoption of inflation targets-other central banks like the Bank of Japan, the European Central Bank, and the U.S. Federal Reserve also operate with a committee structure - it does help to ensure that a broader range of perspectives is taken into account in the decisionmaking process. For many of these central bankssuch as those in Poland, South Africa, and the United Kingdom - this represents a major departure from past practice, where the views of the central bank on monetary policy issues had traditionally been set mainly by an individual (for instance, the governor of the central bank after consulting with senior staff).

Central banks in most emerging market countries have brought in non-career central bankers at the executive level. With the exception of Brazil and South Africa (which has only just announced its intention to adopt an inflation targeting framework), banks in emerging market countries that engage in group decision-making have opted to employ non-career central bankers on a full-time basis and give them executive responsibilities for supervising functions within the central bank (Table 6.2). This stands in marked contrast to the United Kingdom, where the non-career central bankers on the Monetary Policy Committee are involved only in monetary policy decisions and do not have corporate leadership responsibilities. Thus, while it is not an essential requirement for inflation targeting, the employment of non-career central bankers on a full-time basis might be a useful way for a central bank to make full use of the leadership talents available to it.

The building of new relationships with officials from key economic sectors may also enhance the conduct of monetary policy under inflation targeting. Many central banks-not just inflation targeting ones-have sought to forge relationships with 


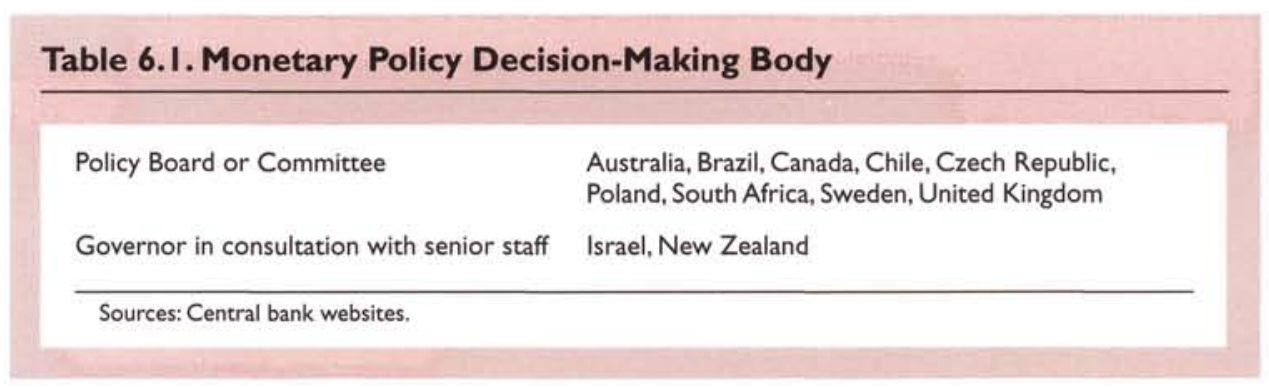

Table 6.2. Role of Non-Central Bank Members

\begin{tabular}{ll}
\hline Full-time with executive responsibilities & Chile, Czech Republic, Poland, Sweden \\
Part-time without executive responsibilities & Australia, South Africa, United Kingdom \\
None & Brazil, Canada, Israel, New Zealand \\
\hline Sources: Central bank websites. &
\end{tabular}

officials from a wide range of institutions, including companies, industry associations, labor unions, and universities. In addition to helping promote a better understanding of monetary policy objectives and the rationale underpinning monetary policy stances, such contacts can be used to supplement the advice provided by economic models with realtime qualitative information on domestic economic conditions.

\section{Monetary Policy Committees}

Formal monetary policy committees in central banks typically vote to approve monetary policy decisions. Most central banks that use a committee structure have adopted a formal voting process because the committee is formally recognized in the governance structure of the central bank and the members typically are not subordinate to the committee chair, which is typically the governor (Tables 6.3 and 6.4). At the Bank of Canada, in contrast, the emphasis on consensus for decisions reflects a desire to foster a collegial environment among the committee members, all of whom are full-time officials that report directly to the Governor.

In most cases, the voting records are not published, however. With the exception of Brazil, the Czech Republic, Poland, the United Kingdom, and to a lesser extent Sweden (where a member of the committee has dissented publicly from the consensus on occasion), inflation targeting central banks typically release press statements that reflect a con- sensus of views, or a range of views without attribution. This approach has been defended on the grounds that nondisclosure promotes freer and more frank discussion of the issues surrounding a monetary policy decision. United Kingdom officials, in contrast, believe that publishing voting records fosters a more transparent policy process and helps to encourage greater independent thinking among the members of the Monetary Policy Committee, since they know they will be held accountable by the public for their votes (Allen, 1999).

There has also been a move toward less discretion in the timing of prospective monetary actions. With the exception of Australia and Canada, the timing of monetary actions was regularized after the adoption of inflation targeting to enhance transparency (Table 6.5). This is partly because the focus is typically on medium-term inflation outlooks in an inflation target framework, and less on day-to-day developments in financial markets. ${ }^{19}$

\section{Internal Resource Requirements}

The move toward inflation targeting has often been accompanied by major reforms to organizational structure and an emphasis on increased dele-

\footnotetext{
${ }^{19} \mathrm{This}$ is also part of a broader trend in central banking, however, since a number of non-inflation targeting central banks, including the U.S. Federal Reserve, have also sought to reduce the amount of discretion in the timing of monetary actions in recent years.
} 
Table 6.3. Votes versus Consensus Decisions

\begin{tabular}{ll}
\hline Single decision maker & New Zealand \\
Consensus & Australia, Canada, Israel \\
Votes & Brazil, Chile, Czech Republic, Poland, South Africa, \\
& Sweden, United Kingdom
\end{tabular}

Sources: Central bank websites.

Table 6.4. Frequency of Monetary Policy Meetings

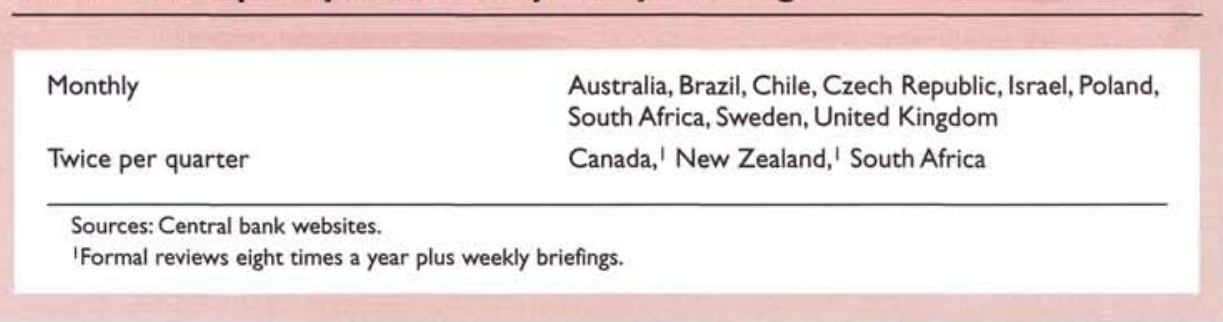

gation of authority. Although not directly related to the introduction of inflation targeting, there has been a major cultural evolution in the Central Bank of Chile from an environment that emphasized explicit controls and regulatory oversight of the financial system to one that focuses on banking supervision and policy formulation. ${ }^{20}$ This factor, combined with major advances in technology and management theory, led the central bank to adopt a more flexible organizational structure, which is less hierarchical and emphasizes decentralization of decision-making authority. Similarly, the Bank of Israel notes that the move away from a monetary policy framework that focused on direct credit, state loans, and foreign exchange controls led it to undergo a major restructuring in the mid-1980s. ${ }^{21}$

The adoption of inflation targeting by emerging market countries was often accompanied by a major shift in the focus of central bank economic analysis and staffing requirements. The introduction of inflation targeting does not appear to have had major implications for central bank resource requirements in industrial countries, since many of these central banks were already well endowed with analytic resources dedicated to advancing the banks' understanding of their economies and mon-

\footnotetext{
${ }^{20}$ See the Banco Central de Chile website at http: $l$ www. bcentral.cl

${ }^{21}$ See Bank of Israel website at http:॥www.bankisrael.gov.il
}

etary transmission mechanisms. In contrast, some central banks in emerging market countries have had to enhance their analytic capacities and reorient their economic analysis and data management activities toward gathering the data, building the models needed to generate regular inflation forecasts, and identifying the main central channels from short-term interest rates to inflation. For example, the Reserve Bank of South Africa is actively looking to recruit and train new staff that could help it improve its economic monitoring and model building abilities so that it can develop a framework for forecasting inflation and determining the appropriate policy response. In Brazil's case, the adoption of inflation targeting was accompanied by a decision to attract staff with strong skills in economics and modeling techniques and helped to focus the economic analysis and research activities in the central bank. These activities are now dedicated to building the models needed to forecast inflation and improve the central bank's understanding of the monetary transmission mechanism (Leone, 1999). Similar needs have also been identified for emerging market countries that are thinking of adopting inflation targeting in the future.

Inflation targeting also seems to have changed the role played by staff involved in monitoring financial markets. Prior to the adoption of inflation targeting, staff involved in financial market activities, particularly in central banks with fixed exchange rate 


\section{ORGANIZATIONAL IMPLICATIONS FOR CENTRAL BANKS}

Table 6.5.Timing of Policy Actions

$\begin{array}{ll}\text { Discretionary } & \text { Australia, Canada } \\ \text { Linked to policy meeting schedule } & \text { Brazil, Chile, Czech Republic, Israel, New Zealand, } \\ & \text { Poland, South Africa, Sweden, United Kingdom }\end{array}$

Sources: Central bank websites.

regimes, played an active role in monitoring markets on a continuous basis, and executing transactions to ensure that interest rate and exchange rate objectives were achieved. With the advent of inflation targeting, there appears to have been a shift in role for such staff. In inflation targeting, the focus of monetary policy is squarely on the medium term rather than on day-to-day developments in financial markets. As a result, those engaged in monitoring markets now spend more time extracting information on the market's expectations for future inflation and monetary policy stances, and correspondingly less time on monitoring the continuous flow of transactions through the markets. 


\section{Conclusion}

$\mathbf{T}$ his paper summarized the advice on the institutional and operational practicalities of inflation targeting for emerging market countries that have decided to operate monetary policy under this framework. The paper also spelled out the trade-offs raised in the formulation of the inflation targeting framework for emerging market countries and described the approaches to these trade-offs used by countries that practice inflation targeting.

The information summarized in this paper suggests that emerging market countries in comparison to industrial countries seem to prefer a more formal institutional framework in support of inflation targeting. The legal frameworks of all inflation targeting countries explicitly set price or currency stability as the primary objective of the central bank and grant it instrument independence. The institutional frameworks for emerging market countries are more formal than those for industrial countries in that the former tend to modify the central bank legal framework before adopting inflation targeting, and all emerging market countries explicitly limit central bank financing of government deficits in the primary market.

The more formal institutional frameworks for inflation targeting in emerging market countries may reflect differences in their structure and history (Appendix I). They began their inflation targeting frameworks with less credibility, owing to much higher and more variable rates of inflation compared with those of the industrial countries. They have less developed financial systems, which tend to increase their exposure to financial crisis. They also have somewhat higher domestic government debt than the industrial countries, which tends to raise the potential for pressure to monetize fiscal deficits, together with much lower broad money to GDP ratios, implying that monetization of a given deficit is more inflationary. Finally, emerging market countries are more vulnerable to exchange rate crises. These characteristics of emerging market countries may accentuate the principal-agent problems inherent in central banking by making it more difficult for the public to monitor the performance and credibility of the central bank, thereby leading emerging market countries to impose more formal arrangements.

Differences in the operation and design of inflation targeting between emerging market and industrial countries are also suggested by the information summarized in this paper. Central banks in emerging market countries rely less on statistical models in the conduct of monetary policy. These central banks appear to intervene more frequently in foreign exchange markets than their counterparts in industrial countries. The design of inflation targets in emerging market countries is characterized by shorter horizons, and by inflation target bands rather than point targets. These differences may also reflect structural differences with industrial countries. Ongoing structural changes in underlying economic relationships are more prevalent in emerging market countries, which are inclined to be more vulnerable to shocks, especially volatile capital flows. Finally, policy transmission in the more open emerging market countries operates largely through the direct short-term exchange rate pass-through channel.

Most central banks in emerging market countries have taken important organizational steps to enhance their capacity to apply greater judgment and foster transparency and accountability. These steps can be particularly challenging for emerging market central banks that have traditionally operated with controls and regulations and have been reluctant to communicate their policy intentions and economic outlooks. Most have improved their governance structure by incorporating a broader range of perspectives into the monetary policy decision-making process, and by reforming their organizational structure with a view to delegating authority.

Finally, several emerging market countries during the transition to full-fledged inflation targeting have been faced with the challenge of disinflating to the long-run inflation objective. The experiences of Chile, Israel, and Poland suggest that a gradual shift from a crawling exchange rate regime to an inflation targeting framework is feasible given supportive economic and fiscal policies to manage the transi- 
tion and minimize the risk of the central bank being confronted by conflicting objectives. One issue that cannot yet be resolved, however, is whether an inflation targeting framework is suitable for countries that want to disinflate from higher rates of inflation. So far, no country with a rate of inflation greater than 30 percent has begun the transition to inflation targeting. 


\section{Appendix I Economic Structure of Emerging Market Inflation Targeters}

\begin{abstract}
$\mathbf{T}$
his annex compares macroeconomic indicators for emerging market countries that target inflation with those for other emerging market countries, and those for inflation targeting industrial countries. The first comparison is intended to discern any systematic differences between the emerging market countries that have adopted inflation targeting and comparable emerging market countries that use other monetary policy frameworks. The second comparison aims to identify any disparities between inflation targeting emerging market and industrial countries that could help improve understanding of the differences in inflation targeting practices discussed in this paper's conclusion.
\end{abstract}

\section{Emerging Market Countries: Inflation Targeters vs. Non-inflation Targeters}

The six emerging market countries that target inflation (Table A1.1) are larger and more developed than are other emerging market countries. These comparisons are based on data for the developing countries in the World Economic Outlook database. Excluding large oil exporting countries and small island countries-as these two country groups generally operate in different monetary policy environments, there are a total of 118 developing coun-

Table Al.I. Emerging Market Countries Ranked by GDP and GDP Per Capita, 19981,2

\begin{tabular}{|c|c|c|c|c|c|}
\hline \multicolumn{6}{|c|}{$\begin{array}{c}\text { GDP } \\
\text { (In billions of U.S. dollars) }\end{array}$} \\
\hline People's Rep. of China & 946.2 & Poland & 157.2 & Egypt & 81.1 \\
\hline Brazil & 775.5 & South Africa & 133.9 & Chile & 72.8 \\
\hline Mexico & 420.9 & Thailand & 112.1 & Malaysia & 72.5 \\
\hline India & 415.8 & Colombia & 99.4 & Philippines & 65.5 \\
\hline Argentina & 298.1 & Israel & 99.0 & Peru & 62.8 \\
\hline Russia & 277.8 & Venezuela & 95.4 & Pakistan & 62.6 \\
\hline Turkey & 200.8 & Indonesia & 94.2 & Czech Republic & 55.7 \\
\hline Myanmar & 189.8 & & & & \\
\hline \multicolumn{6}{|c|}{$\begin{array}{c}\text { Per Capita GDP } \\
\text { (In thousands of U.S. dollars) }\end{array}$} \\
\hline Israel & $|6,59|$ & Hungary & 4,658 & Malaysia & 3,411 \\
\hline Slovenia & 10,058 & Brazil & 4,552 & Estonia & 3,397 \\
\hline Argentina & 8,341 & Mexico & 4,199 & Botswana & 3,274 \\
\hline Uruguay & 6,886 & Venezuela & 4,115 & Panama & 3,254 \\
\hline Czech Republic & 5,421 & Poland & 4,060 & South Africa & 3,164 \\
\hline Chile & 5,042 & Myanmar & 4,037 & Turkey & 3,087 \\
\hline Lebanon & 4,874 & Slovak Republic & 3,786 & & \\
\hline Croatia & 4,660 & Gabon & 3,768 & & \\
\hline
\end{tabular}

Source: World Economic Outlook database.

IInflation targeting countries are marked in bold. This table ranks the top 22 developing countries according to GDP and per capita GDP.

${ }^{2}$ Excludes large oil exporters and small island countries. 


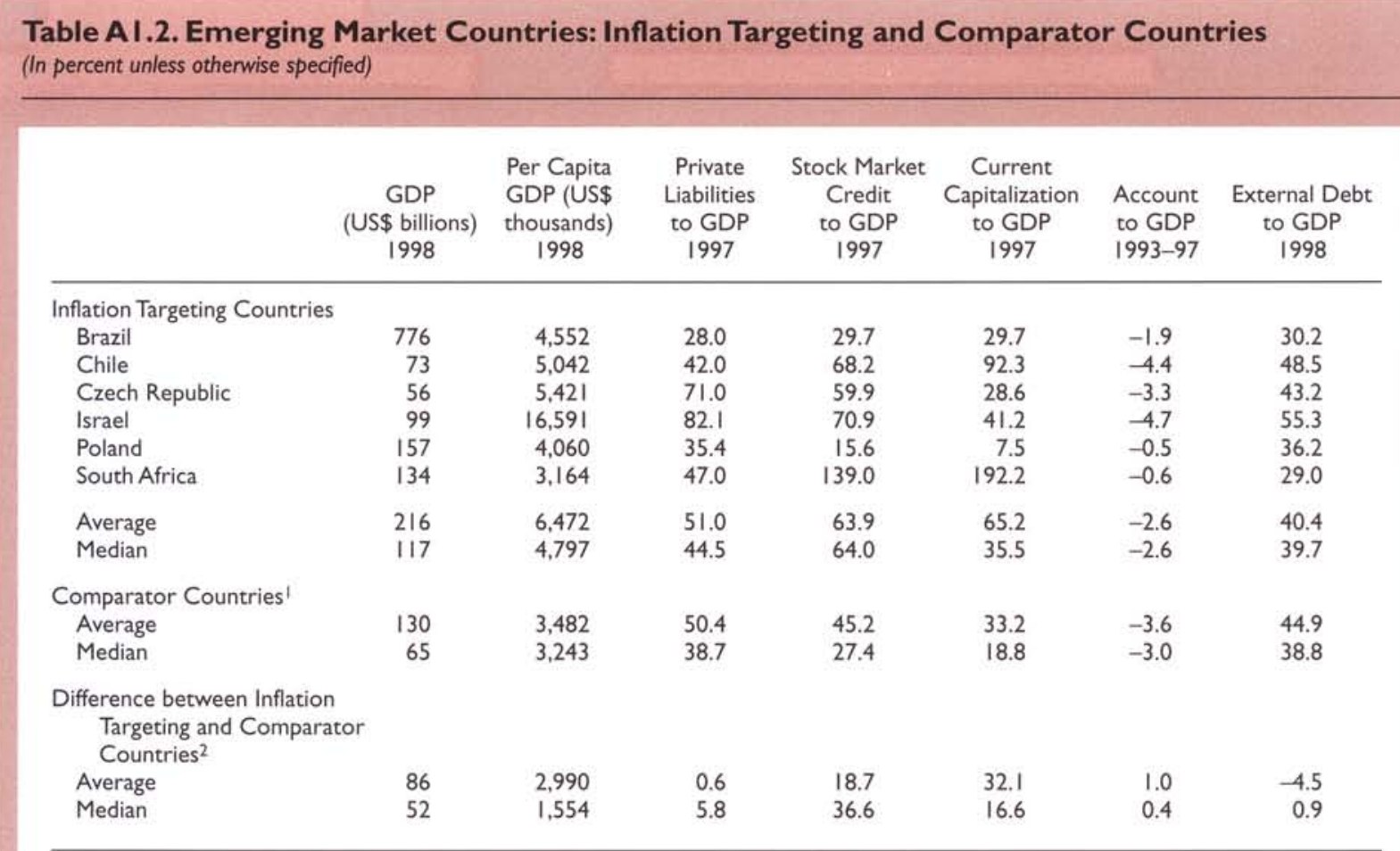

Sources: World Economic Outlook database; Beck and others (1999); and IMF Israel: Selected Issues, IMF Staff Country report No. $99 / 40$.

'Argentina, Belize, Botswana, People's Republic of China, Colombia, Croatia, Egypt, Estonia, Hungary, India, Indonesia, Lebanon, Malaysia, Mexico, Myanmar, Pakistan, Panama, Peru, Philippines, Russia, Slovak Republic, Slovenia, Thailand, Turkey, Uruguay, and Venezuela.

${ }^{2}$ Differences are expressed in percentage points for the ratios given in the table.

tries. ${ }^{22}$ The inflation targeting countries are largethey rank in the top quintile of the 118 developing countries by total 1998 GDP in U.S. dollars (Table A1.1). These countries also rank in the top quintile by per capita GDP in U.S. dollars, indicating that they are generally more developed.

The inflation targeting countries have better developed domestic financial systems according to standard indicators of financial market development. Since only the larger and more advanced developing countries have adopted inflation targeting, these comparisons are between the six inflation targeting countries and the 32 developing countries that are comparable in terms of GDP levels and per capita GDP (i.e., the combination of the top 22 developing countries by total GDP and top 23 developing countries by per capita GDP). The ratio of liquid liabilities to GDP is slightly higher for the inflation targeting countries on average and six percentage points greater by median relative to the comparator group (Table A1.2). The average ratio of private credit (including deposit banks and other fi-

\footnotetext{
${ }^{22}$ Israel was reclassified in 1997 from developing country to advanced country but is included here as a developing country because it adopted inflation targeting in 1991.
}

nancial institutions) for the inflation targeting countries is some 19 percentage points higher than the corresponding ratio for the other countries. Similarly, the stock market capitalization to GDP ratio is nearly twice as large for the inflation targeting emerging market countries. This relatively high level of financial sector development may help explain why all the inflation targeting emerging market countries are able to conduct monetary policy with indirect instruments and short-run interest rates as operating targets.

Indicators of the external position do not show marked differences between the inflation targeting countries and the comparator emerging market countries. The average and median current account deficit during 1993-97, prior to the recent episode of turbulence in international financial markets, is slightly lower for the inflation targeting countries. In a similar vein, the external debt to GDP ratios are almost the same for the two groups of countries.

However, inflation targeting emerging market countries have higher sovereign credit ratings. As of May 2000, Moody's assigned investment grade sovereign credit ratings to five of the six inflation targeting countries. Only nine of the 26 comparable emerging market countries enjoyed investment grade ratings. 
Table Al .3. Key Financial Ratios for Inflation Targeters'

\begin{tabular}{|c|c|c|c|c|c|c|c|c|}
\hline & $\begin{array}{l}\text { Liquid } \\
\text { Liabilities } \\
\text { to GDP } \\
1997\end{array}$ & $\begin{array}{c}\text { Private Credit } \\
\text { to GDP } \\
1997\end{array}$ & $\begin{array}{c}\text { Stock Market } \\
\text { Capitalization } \\
\text { to GDP } \\
1997\end{array}$ & $\begin{array}{c}\text { Reserve } \\
\text { Money to GDP } \\
1997\end{array}$ & $\begin{array}{c}\text { Fiscal } \\
\text { Balance to GDP } \\
\text { (average, } t-2 \text { to } t \text { ) }\end{array}$ & $\begin{array}{l}\text { General } \\
\text { Government } \\
\text { Net Debt } \\
\text { to GDP } \\
1997^{2}\end{array}$ & $\begin{array}{l}\text { Current Account } \\
\text { Balance to GDP } \\
\text { (average, } t-2 \text { to } t \text { ) }\end{array}$ & $\begin{array}{c}\text { Ratio of } \\
\text { Imports and } \\
\text { Exports to GDP } \\
\text { (average, } t-2 \text { to } t \text { ) }\end{array}$ \\
\hline \multicolumn{9}{|c|}{ Emerging Market Countries } \\
\hline Brazil & 28.0 & 29.7 & 29.7 & 26.2 & -7.7 & 35.7 & -4.1 & 17.7 \\
\hline Chile & 42.0 & 68.2 & 92.3 & 101.9 & 0.1 & $\ldots$ & -4.7 & 55.1 \\
\hline Czech Republic & 71.0 & 59.9 & 28.6 & 27.8 & -0.4 & 12.8 & -5.4 & 113.2 \\
\hline Israel & 82.1 & 70.9 & 41.2 & 21.7 & -2.9 & 90.1 & -2.3 & 71.1 \\
\hline Poland & 35.4 & 15.6 & 7.5 & 29.2 & -3.1 & 43.8 & -4.6 & 53.5 \\
\hline South Africa & 47.0 & 139.0 & 192.2 & 9.5 & -2.7 & 48.1 & -1.0 & 51.2 \\
\hline Average & 51.0 & 63.9 & 65.2 & 36.0 & -2.8 & 46.1 & -3.7 & 60.3 \\
\hline Median & 44.5 & 64.0 & 35.5 & 27.0 & -2.8 & 43.8 & -4.3 & 53.1 \\
\hline \multicolumn{9}{|l|}{ Industrial Countries } \\
\hline Australia & 65.0 & 77.0 & 153.0 & 9.8 & -3.9 & 25.5 & -3.5 & 35.5 \\
\hline Canada & 77.0 & 86.0 & 88.0 & 6.6 & -5.0 & 65.5 & -3.7 & 51.1 \\
\hline Finland & 51.0 & 55.0 & 59.0 & 10.2 & -4.6 & -18.5 & -3.8 & 52.3 \\
\hline New Zealand & 84.0 & 95.0 & 99.0 & 2.8 & -1.5 & 25.4 & -3.3 & 51.8 \\
\hline Spain & 75.0 & 76.0 & 50.0 & $\ldots$ & -5.6 & 49.0 & -2.0 & 38.7 \\
\hline Sweden & 46.0 & 57.0 & 115.0 & 11.0 & -6.8 & 18.3 & -2.3 & 57.3 \\
\hline United Kingdom & 105.0 & 120.0 & 147.0 & 4.2 & -3.3 & 40.3 & -2.2 & 48.9 \\
\hline Average & 72.0 & 81.0 & 102.0 & 7.4 & -4.4 & 29.4 & -3.0 & 48.0 \\
\hline Median & 75.0 & 77.0 & 99.0 & 8.2 & -4.6 & 25.5 & -3.3 & 51.1 \\
\hline \multicolumn{9}{|c|}{$\begin{array}{l}\text { Difference between Emerging Market } \\
\text { and Industrial Countries }\end{array}$} \\
\hline Average & -20.9 & -17.1 & -36.3 & 28.6 & 1.6 & 16.7 & -0.7 & 12.3 \\
\hline Median & -30.3 & -13.0 & -63.9 & 18.8 & 1.8 & 18.2 & -1.0 & 3.2 \\
\hline
\end{tabular}




\begin{tabular}{|c|c|c|c|c|}
\hline & $\begin{array}{l}\text { Industrial } \\
\text { Market } \\
\text { Countries }\end{array}$ & $\begin{array}{c}\text { Emerging } \\
\text { Market } \\
\text { Countries }\end{array}$ & Total & $\begin{array}{c}\text { Emerging Market } \\
\text { Countries as } \\
\text { Share of Total }\end{array}$ \\
\hline Number of countries & 20 & 30 & 50 & $60.0 \%$ \\
\hline Number of currency crises & 42 & 116 & 158 & $73.4 \%$ \\
\hline Number of currency crashes & 5 & 50 & 55 & $91.3 \%$ \\
\hline
\end{tabular}

Source: Aziz and others (2000).

\section{Inflation Targeters: Emerging Market Countries vs. Industrial Countries}

The inflation targeting emerging market countries began their inflation targeting frameworks with much higher and more variable rates of inflation compared to the industrial countries. The rate of consumer price inflation at the month during which the transition to inflation targeting began averaged 12.4 percent for the emerging market countries, compared to an average 3.6 percent for the industrial countries (see Table 4.3). Moreover, the standard deviation of monthly inflation during the five years prior to the adoption of inflation targeting was higher by a factor of five for the emerging market countries.

The emerging market countries that target inflation have less developed financial systems in comparison to their industrial country counterparts. The emerging market countries have much lower average and median ratios of liquid liabilities to GDP, private credit to GDP, and stock market capitalization to GDP, relative to the industrial countries (see Table A1.3, page 41). Similarly, the ratio of reserve money to GDP is much higher for the emerging market countries.

Inflation targeting emerging market countries have much more open economies than their industrial country counterparts. Ratios of traded goods and services to GDP are significantly higher for the emerging market countries (Table A1.3). The emerging market countries have a slightly narrower current account deficit on average, but a much wider range.

Emerging market countries have a narrower fiscal deficit but a somewhat higher level of domestic debt than the industrial countries. The average fiscal balance to GDP ratio during the three years prior to the adoption of inflation targeting was 2.5 percentage points higher for the emerging market countries. In contrast, their domestic debt to GDP ratio was around 17 percentage points lower.

Emerging market countries are more vulnerable to currency crises and crashes relative to industrial countries. This comparison draws on the analysis of Aziz and others (2000), which covers 50 countries during 1975-97 (Table A1.4). A currency crisis occurs when an exchange rate pressure index, which is based on the exchange rate and international reserves, breaches a predefined threshold. ${ }^{23} \mathrm{~A}$ crash is a crisis where the exchange rate pressure consists mostly of devaluation. Emerging market countries comprised 60 percent of the sample, but account for 73 percent of the crises and more than 90 percent of the crashes. These results suggest that emerging market countries are much more vulnerable to an exchange rate crash than are industrial countries.

Finally, emerging market countries appear to be subject to larger real economic shocks than the industrial countries. As mentioned above, inflation is more variable for the emerging market countries. Moreover, the standard deviation of real growth during the 12 years prior to the adoption of inflation targeting was three times higher for emerging market countries compared to the industrial countries. In addition, the literature suggests that real shocks are more severe for emerging market countries. For example, Agénor and others (1999) conclude that output volatility is higher and more persistent for middle-income developing countries than for industrial countries, and that supply shocks drive business cycles in these developing countries. Kouparitsas (1996) concludes that output volatility in emerging market countries reflects the transmission of shocks originating in the industrial countries to emerging market countries through international goods and assets markets.

\footnotetext{
${ }^{23}$ The index consists of depreciation and reserve decumulation, with weights chosen to equalize the variance of the two components to avoid the possibility of one component dominating the index. Crises were classified as observations for which the index exceded 1.5 times the pooled standard deviation of the calculated index plus the pooled mean of the calculated index. For any one country, crises identified within 18 months of a previous crisis were excluded. A crash is identified as a crisis when the currency component of the index accounts for 75 percent of the index at the time the index signals a crisis.
} 


\section{Appendix II Institutional Aspects of Inflation Targeting}

Table A2. I. Institutional Aspects of Inflation Targeting in Emerging Market Countries (As of March 2000)

\begin{tabular}{|c|c|c|c|c|c|}
\hline Country & $\begin{array}{c}\text { Date } \\
\text { Introduced }\end{array}$ & $\begin{array}{c}\text { Target } \\
\text { Inflation Rate }\end{array}$ & Target Index & Escape Clauses & Target Set By \\
\hline Brazil & June 1999 & $\begin{array}{l}1999: 8 \%( \pm 2 \%) \\
2000: 6 \%( \pm 2 \%) \\
2001: 4 \%( \pm 2 \%)\end{array}$ & Total CPI & None & $\begin{array}{l}\text { Government in } \\
\text { consultation with the } \\
\text { Central Bank }\end{array}$ \\
\hline Chile & Sep. 1999 & $\begin{array}{l}1991: 18 \% \\
1992: 15-20 \% \\
1993: 10-12 \% \\
1994: 9-11 \% \\
1995: 8 \% \\
1996: 6.5 \% 1 \\
1997: 5.5 \% 1 \\
1998: 4.5 \% 1 \\
1999: 4.3 \% 1 \\
2000: 3.5 \% 1 \\
2001 \text { onwards: } 2-4 \%\end{array}$ & Total CPI & None & Central Bank \\
\hline Czech Republic & Dec. 1997 & $\begin{array}{l}\text { 1998: } 5.5-6.5 \% \\
1999: 4-5 \% \\
2000: 3.5-5.5 \% \\
2001: 2-4 \% \\
2005: 1-3 \%\end{array}$ & $\begin{array}{l}\text { Underlying CPI } \\
\text { (excluding } \\
\text { regulated prices } \\
\text { and indirect } \\
\text { taxes) }\end{array}$ & $\begin{array}{l}\text { Global raw material price shocks; } \\
\text { exchange rate movements unconnected } \\
\text { with domestic economic fundamentals } \\
\text { and monetary policy; agricultural } \\
\text { production shocks; and natural disasters }\end{array}$ & Central Bank \\
\hline Israel & June 1997 & $\begin{array}{l}1992: 14-15 \% \\
1993: 11 \% \\
1994: 11 \% \\
1995: 8-11 \% \\
1996: 8-10 \% \\
1997: 7-10 \% \\
1998: 7-10 \% \\
1999: 4 \% \\
2000: 3-4 \% \\
2001: 3-4 \%\end{array}$ & Total CPI & None & $\begin{array}{l}\text { Government in } \\
\text { consultation with the } \\
\text { Central Bank }\end{array}$ \\
\hline Poland & Mar. 1999 & $\begin{array}{l}1998:<9.5 \% \\
1999: 6.6-7.8 \% \\
2000: 5.4-6.8 \% \\
2003:<4 \%\end{array}$ & Total CPI & None & Central Bank \\
\hline South Africa & Feb. 2000 & $2002: 3-6 \%$ & $\begin{array}{l}\text { Underlying CPI } \\
\text { (excluding interest } \\
\text { costs) }\end{array}$ & $\begin{array}{l}\text { Major unforeseen events outside } \\
\text { Central Bank control }\end{array}$ & $\begin{array}{l}\text { Jointly by government } \\
\text { and Central Bank }\end{array}$ \\
\hline
\end{tabular}


Table A2.1 (concluded)

\begin{tabular}{|c|c|c|c|c|}
\hline Country & $\begin{array}{l}\text { Monetary Policy } \\
\text { Operating Target }\end{array}$ & $\begin{array}{l}\text { Monetary Policy } \\
\text { Transmission Lags }\end{array}$ & $\begin{array}{l}\text { Current Exchange } \\
\text { Rate Regime }\end{array}$ & $\begin{array}{c}\text { Central Bank } \\
\text { Legal Framework }\end{array}$ \\
\hline \multirow[t]{2}{*}{ Brazil } & Overnight interest rate & $\begin{array}{l}6-9 \text { months for interest } \\
\text { rate changes }\end{array}$ & Floating & Instrument independence \\
\hline & & $\begin{array}{l}\text { Exchange rate affects inflation } \\
\text { contemporaneously }\end{array}$ & & $\begin{array}{l}\text { Loans to National Treasury } \\
\text { prohibited } \\
\text { Currency stability and price } \\
\text { stability as objectives }\end{array}$ \\
\hline Chile & $\begin{array}{l}\text { Overnight interest rate } \\
\text { (real terms) }\end{array}$ & $\begin{array}{l}\text { Previously widespread } \\
\text { indexation has led to quick } \\
\text { transmission from exchange } \\
\text { rate and wage shocks to } \\
\text { inflation. Recently, } \\
\text { transmission has lengthened } \\
\text { to I-2 years }\end{array}$ & $\begin{array}{l}\text { Floating } \\
\text { Exchange rate band } \\
\text { used before Sep. } 1999 \\
\text { occasionally led to } \\
\text { conflicts between } \\
\text { exchange rate and } \\
\text { inflation objectives }\end{array}$ & $\begin{array}{l}\text { Instrument independence, } \\
\text { but Minister of Finance can } \\
\text { suspend Board decisions } \\
\text { for two weeks for } \\
\text { decisions unanimously taken } \\
\text { by the Board } \\
\text { Loans to government } \\
\text { prohibited } \\
\text { Currency stability as primary } \\
\text { objective }\end{array}$ \\
\hline Czech Republic & I-2 week repo rate & $\begin{array}{l}\text { Linkages affected by high } \\
\text { levels of nonperforming } \\
\text { loans in the financial sector } \\
\text { and weak corporate sector } \\
\text { profitability }\end{array}$ & Floating & $\begin{array}{l}\text { Instrument independence } \\
\text { Loans to government } \\
\text { restricted } \\
\text { Currency stability as primary } \\
\text { objective }\end{array}$ \\
\hline Israel & Short-term & $\begin{array}{l}\text { Widespread indexation has } \\
\text { led to quick transmission } \\
\text { from exchange rate and } \\
\text { wage shocks to inflation }\end{array}$ & $\begin{array}{l}\text { Crawling exchange rate } \\
\text { band } \\
\text { Band has been widened } \\
\text { several times since } 1991\end{array}$ & $\begin{array}{l}\text { Instrument independence } \\
\text { Loans to government } \\
\text { prohibited } \\
\text { Multiple objectives } \\
\text { (currency stability and real } \\
\text { objectives) }\end{array}$ \\
\hline Poland & 28-day NBP bill rate & $\begin{array}{l}\text { Linkages impeded by } \\
\text { underdeveloped financial } \\
\text { markets }\end{array}$ & Floating & $\begin{array}{l}\text { Instrument independence } \\
\text { Loans to government } \\
\text { prohibited } \\
\text { Price stability as primary } \\
\text { objective }\end{array}$ \\
\hline South Africa & Overnight interest rate & $\begin{array}{l}\text { Lagged effect of interest } \\
\text { rate changes on inflation. } \\
\text { Effect on broad money } \\
\text { is weak }\end{array}$ & Floating & $\begin{array}{l}\text { Instrument independence } \\
\text { Loans to government } \\
\text { prohibited } \\
\text { Currency stability as primary } \\
\text { objective }\end{array}$ \\
\hline
\end{tabular}

Sources: Central bank websites and publications; discussions with central banks; and Bernanke and others (1999).

Includes unspecified plus/minus range. 
Table A2.2. Institutional Aspects of Inflation Targeting in Industrial Countries' (As of March 2000)

\begin{tabular}{|c|c|c|c|c|c|c|c|}
\hline Country & $\begin{array}{l}\text { Date } \\
\text { Introduced }\end{array}$ & \multicolumn{2}{|c|}{$\begin{array}{c}\text { Target } \\
\text { Inflation Rate }\end{array}$} & \multicolumn{2}{|c|}{ Target Index } & Escape Clauses & Target Set By \\
\hline Australia & Mid-1993 & \multicolumn{2}{|c|}{$\begin{array}{l}2-3 \% \text { on average over } \\
\text { business cycle }\end{array}$} & \multicolumn{2}{|c|}{ Total $\left.C P\right|^{2}$} & None & $\begin{array}{l}\text { Jointly by government } \\
\text { and Central Bank }\end{array}$ \\
\hline \multirow[t]{2}{*}{ Canada } & Feb. 1991 & \multicolumn{2}{|c|}{$\begin{array}{l}\text { Dec. } 91: 3-5 \% \\
\text { (excluding goods } \\
\text { and services tax) } \\
\text { Dec. } 92: 2-4 \% \\
\text { June } 94: 1.5-3.5 \% \\
\text { Since Dec. } 95: 1-3 \%\end{array}$} & \multirow{2}{*}{\multicolumn{2}{|c|}{$\begin{array}{l}\text { Underlying CPI } \\
\text { (excluding food, } \\
\text { energy, and } \\
\text { indirect taxes) }\end{array}$}} & $\begin{array}{l}\text { Aim to get back on track over } \\
2 \text { years in the event of a temporary } \\
\text { price shock affecting inflation by } \\
\text { more than } 0.5 \text { percentage point }\end{array}$ & $\begin{array}{l}\text { Jointly by government } \\
\text { and Central Bank }\end{array}$ \\
\hline & & \multicolumn{2}{|c|}{$\begin{array}{l}1-3 \% \text { range in effect } \\
\text { until Dec. } 2001\end{array}$} & & & \multicolumn{2}{|l|}{$\begin{array}{l}\text { Revision of entire target path under } \\
\text { very exceptional circumstances (major } \\
\text { oil price shock, natural disaster) }\end{array}$} \\
\hline Finland & $\begin{array}{l}\text { Feb. } 1993- \\
\text { June } 1998\end{array}$ & \multicolumn{2}{|c|}{$\begin{array}{l}\text { Annual average } 2 \% \\
\text { by } 1995\end{array}$} & \multicolumn{2}{|c|}{$\begin{array}{l}\text { Underlying CPI } \\
\text { (excluding indirect } \\
\text { taxes, subsidies, } \\
\text { housing prices, and } \\
\text { mortgage interest) }\end{array}$} & None & Central Bank \\
\hline New Zealand & July 1989 & \multicolumn{2}{|c|}{$\begin{array}{l}\text { 1990: } 3-5 \% \\
1991: 2.5-4.5 \% \\
1992: 1.5-3.5 \% \\
1993-1996: 0-2 \% \\
\text { Since Dec. } 1996: 0-3 \%\end{array}$} & \multicolumn{2}{|c|}{ Total CPI 4} & $\begin{array}{l}\text { Unusual events will be tolerated } \\
\text { provided they do not generate } \\
\text { general inflationary pressures }\end{array}$ & $\begin{array}{l}\text { Jointly by government } \\
\text { and Central Bank }\end{array}$ \\
\hline Spain & $\begin{array}{l}\text { Nov. } 1994 \\
\text { June } 1998\end{array}$ & \multicolumn{2}{|c|}{$\begin{array}{l}\text { June } 96: 3.5-4 \% \\
\text { Dec. } 97: 2.5 \% \\
1998: 2 \%\end{array}$} & \multicolumn{2}{|c|}{ Total CPI } & None & Central Bank \\
\hline Sweden & Jan. 1993 & \multicolumn{2}{|c|}{ Since 1995: $2 \%( \pm 1 \%)$} & \multicolumn{2}{|c|}{ Total CPI } & None & Central Bank \\
\hline United Kingdom & Oct. 1992 & \multicolumn{2}{|c|}{$\begin{array}{l}\text { 1992-1995: } 1-4 \% \\
\text { Since 1995: } 2.5 \%\end{array}$} & \multicolumn{2}{|c|}{$\begin{array}{l}\text { RPIX (excluding } \\
\text { mortgage interest) }\end{array}$} & None & Government \\
\hline Country & \multicolumn{2}{|c|}{$\begin{array}{l}\text { Monetary Policy } \\
\text { Operating Target }\end{array}$} & \multicolumn{2}{|c|}{$\begin{array}{l}\text { Monetary } \\
\text { Policy } \\
\text { Transmission Lags }\end{array}$} & $\begin{array}{l}\text { Current } \\
\text { Exchange } \\
\text { Rate Regime }\end{array}$ & \multicolumn{2}{|l|}{$\begin{array}{l}\text { Central Bank } \\
\text { Legal Framework }\end{array}$} \\
\hline Australia & \multicolumn{2}{|c|}{$\begin{array}{l}\text { Overnight "cash" interest } \\
\text { rate }\end{array}$} & \multicolumn{2}{|c|}{$\begin{array}{l}6-8 \text { quarters on } \\
\text { average }\end{array}$} & Floating & \multicolumn{2}{|c|}{$\begin{array}{l}\text { However, the Central Bank is required to consult regularly } \\
\text { with the government. There is also a formal dispute resolution } \\
\text { mechanism, which has not been used in recent years } \\
\text { Multiple objectives }\end{array}$} \\
\hline Canada & \multicolumn{2}{|c|}{ Overnight interest rate } & \multicolumn{2}{|c|}{$\begin{array}{l}6-8 \text { quarters on } \\
\text { average }\end{array}$} & Floating & \multicolumn{2}{|c|}{$\begin{array}{l}\text { Instrument independence, but in exceptional circumstances } \\
\text { the Minister of Finance can issue a formal directive to the } \\
\text { Central Bank Governor. }\end{array}$} \\
\hline New Zealand & \multicolumn{2}{|c|}{ Overnight interest rate } & \multicolumn{2}{|c|}{$\begin{array}{l}6-8 \text { quarters on } \\
\text { average }\end{array}$} & Floating & \multicolumn{2}{|c|}{$\begin{array}{l}\text { Instrument independence subject to a requirement that } \\
\text { monetary actions be taken with regard to financial system } \\
\text { soundness }\end{array}$} \\
\hline Sweden & I-week inter & est rate & 5-8 quar & ters & Floating & $\begin{array}{l}\text { Instrument independence } \\
\text { Loans to government prohibited } \\
\text { Price stability as primary objective }\end{array}$ & \\
\hline United Kingdom & Short-term r & epo rate & $\begin{array}{l}8 \text { quarter } \\
\text { average }\end{array}$ & s on & Floating & $\begin{array}{l}\text { Instrument independence } \\
\text { Price stability as primary objective }\end{array}$ & \\
\hline
\end{tabular}

Sources: Central bank websites and publications; discussions with central banks; and Bernanke and others (1999).

"Inflation targeting in Finland and Spain ended in January 1999 when their exchange rate parities were irrevocably fixed with the introduction of the euro. Hence, these countries are excluded from the second panel.

${ }^{2}$ Australia switched from a core measure to the CPI in 1998 when the latter was redefined by the statistical agency to exclude interest charges.

${ }^{3}$ Informal target.

${ }^{4} \mathrm{New}$ Zealand switched from a core measure to the CPI in 1999 when the latter was redefined by the statistical agency to exclude interest charges and section prices. 


\section{Appendix III Country Studies}

\section{Australia}

In April 1993, Australia announced an inflation target with a view to increasing the transparency and credibility of monetary policy and to condition inflation expectations. The inflation target was intended to provide a nominal anchor for monetary policy; this anchor had been missing since 1985 when the Reserve Bank of Australia (RBA) abandoned its monetary targets. Monetary policy in the 1970s and 1980 s often played a supporting role to other economic policies and resulted in relatively high inflation rates (Lowe, 1997). In 1990, when the overall macroeconomic situation started to weaken, the focus of monetary policy changed. Both the RBA and the government stressed that there was an imminent need to engineer a substantial reduction in inflation from the average level of 8 percent in the 1980s (Debelle and Stevens, 1995). The shift in priorities for monetary policy was accompanied by efforts to make the RBA's monetary operations more transparent: the RBA began to publicly explain changes in its monetary policy stance and to announce a target for the cash rate operating target (Battellino and others, 1997). The RBA adopted the inflation targeting framework after inflation had fallen to below 2 percent, thus providing a favorable environment for meeting the target.

Several aspects of Australia's inflation targeting framework are distinct. First, Australia's underlying inflation index comprises only about 50 percent of the consumer price index basket; all components that are volatile or seasonal, subject to administrative price setting, and sensitive to interest rate changes are excluded (RBA, 1994). Second, the RBA is the only central bank to formulate its inflation target as a "thick point" target rather than a narrow band (Debelle and Stevens, 1995). Third, the target is defined as a 2-3 percent rate of underlying inflation on average over the economic cycle. Thus, the RBA does not define a strict time frame over which it has to adjust target deviations, but it stresses the medium-term orientation of monetary policy by defining the target to be fulfilled on average over an economic cycle.
Because Australia's inflation targeting framework is less stringent than that of most other inflation targeters, the RBA has considerable leeway in conducting its monetary policy. The high flexibility is deemed necessary by the explicit requirement that the RBA pursue its monetary policy for price stability by taking into account the short-run implications for real output and employment (RBA, 1996). This obligation has not imposed any restrictions on monetary policy, however, since inflation targeting was introduced. Over the last three years, consumer price inflation has remained at around 2 percent and underlying inflation has been less than 2 percent.

\section{Brazil}

The Central Bank of Brazil (BCB) adopted inflation targeting in June 1999 as its new monetary policy framework. The BCB found the introduction of a new policy framework necessary after Brazil was forced to abandon its crawling exchange rate peg in January 1999. The crawling exchange rate peg had provided a nominal anchor for monetary policy since mid-1994 when it was introduced as part of a stabilization process intended to stop another episode of hyperinflation. Inflation was quickly brought down to single-digit rates by end-1996 and to less than 2 percent by end-1998. The exchange rate, however, came under pressure after the Russian financial crisis in August 1998.

To restore credibility and signal the long-term orientation of monetary policy, the BCB announced in March 1999 its intention to move to an inflation targeting framework by end-June and its goal to reduce inflation to single digits by the last quarter of 1999 . The BCB also tightened monetary policy by increasing interest rates. These measures, together with an IMF-supported financial package, helped to stabilize the Brazilian currency (real), reduce inflation expectations, and establish an economic environment in which the inflation targets were likely to be met (Fraga, 2000). The interim period until the formal adoption of inflation targeting in June 1999 also 
served as an extensive preparatory phase for the new policy framework supported by technical assistance from other inflation targeting central banks and the IMF. The BCB outlined the concrete features of the framework and prepared the publication of an inflation report, and the bank's newly created research department started to develop inflation forecasting models and analyze the monetary transmission mechanism (Bogdanski and others, 2000).

Brazil's inflation targeting framework encompasses the following elements. The National Monetary Council sets the inflation targets based on the proposal by the Minister of Finance. The annual targets are formulated as changes in the broad consumer price index with symmetric tolerance intervals of \pm 2 percent. From 2002 onwards, targets must be announced each year no later than June 30 for two years in advance. Adopting a headline index was regarded as crucial for credibility reasons, since Brazil had experienced several price index manipulations in the past (Bogdanski and others, 2000). The combination of headline inflation with relatively wide corridors in the absence of escape clauses accounts for the vulnerability of the Brazilian economy to economic shocks (Fraga, 2000).

Brazil's inflation targeting framework also comprises a number of measures to ensure accountability and transparency, all of which are very similar to the Bank of England's procedures. If targets are breached, the president of the BCB should issue an open letter to the Minister of Finance explaining the causes of the breaches, measures to be adopted, and the period of time that will be needed for the measures to have an effect. The decisions of the BCB's Monetary Policy Committee, which meets every five weeks, are announced immediately after the meeting, and the minutes are published with a one-week lag. Moreover, the $\mathrm{BCB}$ publishes a sophisticated quarterly inflation report with details on past developments and policy decisions and an analysis of prospective inflation, including inflation forecasts presented in "fan charts."

Brazil's nine months experience with the inflation targeting framework is still too short to draw definite conclusions, but the framework is seen to be off to a "promising start" (Fraga, 2000). With 8.9 percent inflation at end-1999 the first inflation target was met. Short-term interest rates were lowered from 45 percent in March 1999 to 19 percent in March 2000. The exchange rate has floated with limited central bank intervention, GDP growth has slowly resumed, and the current account deficit has decreased.

\section{Canada}

In February 1991, the Bank of Canada (BoC) and the federal government jointly announced the com- mitment of monetary policy to inflation targeting and explicit targets for reducing inflation. During the prior decade, Canadian monetary policy had been conducted without intermediate targets or a specified path to the longer-term objective. The narrowly defined monetary aggregate (M1), which had served as a nominal anchor from 1975 to 1982 , had been dropped as a target since the aggregate had become increasingly unreliable.

The inflation targets have also had an important effect on the functioning of the $\mathrm{BoC}$ and have provided a strong incentive for the Bank to become more forthcoming about how it would operate to achieve them (Thiessen, 1998). As a result, the BoC has taken initiatives to explain more fully its assessment of economic developments and its outlook for output and inflation. It has also clarified how it makes judgments about the actions needed to achieve the targets and how it operates in markets to implement those judgments. Perhaps most importantly, the targets have helped to improve the internal discipline of the policymaking process (Thiessen, 1998). The BoC's commitment to the targets and the need to explain and justify any inability to meet them have resulted in a better focused internal debate on the appropriate policy actions to take, and may well have reduced the likelihood that decisions to take such actions will be postponed.

Canada's first inflation target was set at 3 percent for the year-over-year rate of core consumer price inflation (excluding prices for food and energy and indirect taxes), to be achieved by December 1992. This target was reduced to 2.5 percent for mid-1994 and to 2 percent by the end of 1995 . These targets had a band of plus and minus 1 percentage point around them. Subsequent announcements extended the 1 to 3 percent target range for inflation through to the end of 2001. The government and the central bank now plan to set the appropriate long-run target consistent with price stability before the end of 2001, rendering concrete the long-term commitment of the authorities to achieving and maintaining price stability.

At the time the targets were first announced, there was upward pressure on prices in Canada from two major shocks - the sharp rise in oil prices following the August 1990 Iraqi invasion of Kuwait and from changes in the goods and services tax. These shocks had led the BoC and the government to be concerned about a deterioration of inflation expectations and the possibility of additional upward pressure on wages and prices. By providing a clear indication of the downward path for inflation over the medium term, the key near-term aim of the targets was to help firms and households see beyond these price shocks to the underlying downward trend at which monetary policy was aiming, and to take this into account in their economic decision making. 
Following the initial announcement of the targets in February 1991, inflation fell rapidly, and since 1992, inflation has resided mainly in the lower half of the target range. The speed of the decline in inflation in 1991 caught the authorities by surprise. The decrease reflected a much more severe economic downturn than either the BoC or most other forecasters had expected, owing in part to unexpectedly weak conditions outside Canada, and also to the unwinding of distortions in domestic asset prices associated with the preceding period of inflationary pressures.

There is little evidence to suggest that the 1991 announcement had a significant immediate impact on inflation expectations. Rather, the low realized trend rate of inflation since 1992 was probably the primary factor in shifting inflation expectations downwards (Thiessen, 1998). But the targets may have played a role in convincing the public and markets that the BoC would persevere in its commitment to maintain inflation at the low rates that had been achieved. In more recent years, the $\mathrm{BoC}$ has seen indications that the 2 percent midpoint of the target range is becoming an important anchor for current inflation expectations and for long-range corporate planning.

\section{Chile}

The abandonment of the crawling peg exchange rate regime in September 1999 can be deemed the start of full-fledged inflation targeting in Chile. This followed a long transition period from September 1990, when the Central Bank of Chile (CBC) announced its first annual inflation target for the following year. The CBC began to announce inflation targets after it obtained autonomy through the new central bank law in October 1989. Moreover, inflation, which had fallen from 30 percent in mid-1985 to about 12 percent at the beginning of 1989 , started to rebound, driven by expansionary fiscal policy and increases in oil prices. The CBC's aim in announcing inflation targets was to gradually reduce inflation by providing a focal point anchor for monetary policy that (until September 1999) was supplemental to the existing crawling exchange rate band. Fixing the exchange rate was not considered a credible alternative because of past failures, and monetary targets were deemed problematic in an environment of developing financial markets and volatile money demand (Morandé and Schmidt-Hebbel, 2000).

Inflation targets are announced annually each September for the December-to-December consumer price inflation rate (Corbo, 2000). From 2001 onwards, the target horizon is indefinite and the target is set similarly to industrial country levels ( $2-4$ percent). This was announced in September 1999 in tandem with the abandonment of the crawling peg exchange rate regime. Target ranges were preferred for the first inflation targets, while point targets were announced after inflation fell to single digits. Until May 1995, the operating target of the $\mathrm{CBC}$ was the real rate on indexed CBC paper of 90-day maturity. Since then, the CBC sets the real daily overnight interbank rate mainly through repurchase and reverse repurchase transactions (Landerretche and others, 1999).

The gradual approach to disinflation over an entire decade reflects the aim to achieve stabilization without incurring substantial output costs, which in an environment of widespread indexation was deemed particularly problematic (Landerretche and others, 1999). Inflation inertia was broken only slowly, and inflation targets and actual inflation rates were brought down in steps of one to two percentage points per year, reflecting a number of supply shocks that temporarily hiked food and energy prices (IMF, 1998a). However, those shocks were offset by the strict stance of fiscal policy-fiscal surpluses had been registered since 1988 (Landerretche and others, 1999). The stabilization efforts were challenged in the aftermath of the Asian and Russian financial crises when the peso came under speculative attack on several occasions. The CBC reacted with a combination of nonsterilized foreign exchange interventions and raised the repo rate substantially to defend the currency. Monetary policy was relaxed at end1998 as the financial crises subsided, and the temporary recession that followed helped to push inflation down to its current level.

\section{Czech Republic}

The Czech National Bank (CNB) adopted an inflation targeting framework in December 1997, and the CNB published a comprehensive statement with details of the new strategy in April 1999. The decision to introduce inflation targeting was motivated by the desire to reduce inflation below a 10 percent threshold, around which it had fluctuated since 1994, against the background of a move to a floating exchange rate regime in May 1997 after speculative attacks prompted by the Asian financial crisis and the Czech Republic's prospective membership of the European Union.

Prior to inflation targeting, the monetary policy framework of the CNB was built around exchange rate and monetary targets. From 1991 to February 1996, the Czech currency (koruna) was tightly pegged to a currency basket, and the CNB announced growth targets for broad money. The disinflation process was stalled by large capital inflows that limited the CNB's ability to achieve the domestic dimension of currency stability. With the widening of the exchange rate band in February 1996, the CNB 
placed more emphasis on monetary targets and the bank was able to raise interest rates to respond to inflationary pressures. Rising external and fiscal imbalances and contagion effects of the Asian crisis triggered speculative attacks against the koruna, however. These were initially resisted with a sharp rise in interest rates before the move to a floating rate (Clinton, 2000). Immediately after the koruna's flotation monetary policy was based on money growth targets, despite the uncertain and unstable relation between money growth and inflation, together with informal exchange rate targets against the deutsche mark (IMF, 1998b).

The Czech Republic's inflation targeting framework is marked by several differences with those of other countries. First, the initiative to adopt the new framework was entirely driven by the central bank. The CNB eventually gained support by the government, which incorporated the long-term monetary strategy into the central document that defines the government's economic policy orientation in the runup to European Union accession (CNB, 1999c). The CNB's intention to commit the government to the inflation target is also reflected in the time frame for target announcements, which give the government the opportunity to implement them into its state budget draft (CNB, 1999a). Second, the share of regulated prices in the Czech economy is still relatively high. Consequently, the CNB announces its inflation targets for "net inflation," which exclude regulated prices and effects of changes in taxes. The index is calculated by the independent Czech Statistical Office to ensure the data's integrity. Moreover, the CNB has defined a set of escape clauses that justifies deviations from the medium-term inflation target (CNB, 1999a). Third, with the adoption of inflation targeting, the CNB announced a target path for the next three years and its long-run target to be reached by 2005 .

The introduction of inflation targets helped to break inflation inertia. The first two inflation targets were undershot and at end-1999 net inflation stood at 0.5 percent while consumer price inflation was somewhat higher at 2.6 percent. The reduction in inflation was brought about by the tight monetary policy stance throughout 1998 as well as the drop in oil and food prices and the compression of domestic and foreign demand. Inflation expectations fell more slowly, however, and came down considerably only at end-1998 after actual inflation had fallen. Thereafter, the CNB gradually eased monetary policy by lowering the repo rate.

\section{Finland}

Finland operated an explicit inflation targeting framework from February 1993 until the introduc- tion of the single European currency (euro) in January 1999. It adopted inflation targeting after abandoning the peg of the Finnish currency (markka) to the European currency unit in September 1992. The motive for inflation targeting was to increase the transparency and credibility of monetary policy to create room for lowering interest rates, since Finland's economy was in a full-scale economic and banking crisis at the beginning of the 1990s. Real GDP shrank by 3 percent a year from 1990-92 in response to falling private consumption and investment as well as the collapse of trade with the former Soviet republics. As a result, Finnish inflation was relatively low at the onset of inflation targeting (2.6 percent in 1992).

The Bank of Finland (BoF) specified its inflation target as an annual average of about 2 percent, measured by the indicator of underlying inflation. For the first target, the BoF allowed for an adjustment path of two years. Because consumer price inflation was thought to obscure underlying inflation trends, the effect of taxes, subsidies, house prices, and mortgage costs were excluded in the inflation target (Pikkarainen and Tyväinen, 1993). In contrast to other inflation targeting central banks, the BoF never published an inflation report and the transparency of monetary policy remained relatively low. Also, changes in its operating procedures were communicated with a lag. From December 1994 onwards the BoF conducted repurchase agreements-its main policy instrument-entirely through volume tenders to give the market clear guidance and to reduce the fluctuations in interest rates (Pikkarainen, 1996). And, the BoF gained de jure political independence relatively late, in January 1998, when the Bank of Finland Act was amended according to the requirements of the second stage of European Economic and Monetary Union.

Despite the sharp depreciation of the Finnish markka at end-1992 and the beginning of 1993, inflation was subdued below its target rate nearly from the first day of inflation targeting. The initial reduction of inflation, however, reflected the outcome of the severe depression rather than monetary policy. Inflation expectations remained above the target rate until 1995. Only when the new government announced a fiscal consolidation package and the $\mathrm{BoF}$ decisively tightened monetary policy, did inflation expectations fall considerably. As a consequence, the markka recovered to its level before the currency's flotation and the strengthening of the overall economic situation.

A special feature of Finland's inflation targeting framework was the country's gradual move toward European integration. Finland became a member of the European Union in January 1995, joined the Exchange Rate Mechanism (ERM) of the European 
Monetary System with a band of \pm 15 percent in October 1996, and in May 1998 was chosen to be among the countries that would adopt the euro in January 1999. The move to the wide band of the ERM did not impose any constraints on the BoF's monetary policy; although the pass-through from exchange rate movements to inflation had weakened with the markka's flotation (Tyväinen, 1997), the $\mathrm{BoF}$ held the markka in a rather narrow corridor of about \pm 2.5 percent to the deutsche mark.

\section{Israel}

Israel began its transition toward inflation targeting in conjunction with the announcement of a crawling exchange rate band in December 1991 and can be said to have moved to a full-fledged inflation targeting framework with the widening of the exchange rate band to 28 percent in June 1997. The adoption of inflation targets in Israel took place after inflation had successfully been brought down from triple digit numbers during the mid-1980s to the 15 to 20 percent range. At the same time, however, the gradual liberalization of financial markets, and capital restrictions increasingly made it more difficult and costly to defend the currency. The Israeli currency (shekel) was devalued several times between 1986 and 1991, and after another speculative attack at end-1991 Israel switched from a peg to a crawling band with a width of \pm 5 percent. Inflation targets became an integral part of this new framework since they helped to define the upward slope of the crawl. Since then, the width of the exchange rate band has been increased on several occasions and the focus of monetary policy has shifted toward inflation targeting (Leiderman and Bufman, 2000).

The institutional and operational features of Israel's inflation targeting framework evolved over time. The targets are set annually for the Decemberover-December change in the consumer price inflation (CPI). The CPI is the preferred price index because indexation of financial and wage contracts to CPI is still widespread (Bernanke and others, 1999). Nevertheless, the Bank of Israel (BoI) also pays close attention to different measures of underlying inflation when making its policy decisions. The first three annual inflation targets were announced jointly by the Ministry of Finance (MoF) and the BoI; thereafter, the targets were announced by the MoF in consultation with the BoI. On a few occasions, the $\mathrm{BoI}$ considered the targets to be lenient and publicly raised their reservations.

In the first three years, very narrow target ranges or point targets were announced to focus expectations. After the 1994 target was overshot by about 6 percentage points, the point targets were replaced by tar- get ranges of 2 or 3 percentage points wide. An explicit medium-term orientation for monetary policy was established in 1996 when the government announced a long-term objective of bringing inflation down to the average rate of the Organization for Economic Cooperation and Development (OECD) countries by 2001. In 1999, the MoF announced two-year targets of 3-4 percent for 2000 and 2001. The BoI only recently started publishing semi-annual inflation reports (March 1998), but it refrains from making explicit quantitative inflation forecasts. The quarterly published statements of "Recent Economic Developments" are entirely backward looking. Since August 1998, the BoI governor is required to publicly explain deviations of expected inflation from the target of more than one percentage point.

Overall, Israel's experience with inflation targeting can be broadly considered a success. Most inflation targets were met and inflation came down from 18 percent at end-1991 to about 1 percent at end1999. Until 1998, however, the pace of disinflation was rather slow and Israel experienced three episodes of inflation pressures: in late 1994, the first half of 1996, and late 1998 (Leiderman and Bar-Or, 2000). The BoI's decisive tightening of monetary policy in 1994 to counteract the strong target overshooting by 6 percentage points is viewed as a critical point for the overall success of the framework. In 1994, the BoI also emphasized the role of the inflation target and made clear that in case of conflicts with the exchange rate target, the former would take precedence (Bernanke and others, 1999). Ambiguity on this point before 1994 has contributed to the rise in inflation expectations (Leiderman and Bar-Or, 2000). Tight monetary policy at end-1998, which was hardly eased over the course of 1999, and the slowdown in economic activity that year brought inflation down in the last quarter of 1999 to its longrun path (Bank of Israel, 2000). Disinflation was facilitated by trend improvements in productivity, reflecting immigration and structural policies, as well as a program of fiscal consolidation.

\section{New Zealand}

New Zealand was the first country to adopt inflation targeting in December 1989 with the passage of the Reserve Bank of New Zealand Act (RBA). New Zealand's long experience with high and variable inflation helps explain its early adoption of inflation targeting - consumer price inflation rose almost fivefold during the 15 years of generally disappointing economic performance triggered by the oil shock of 1973. A brief but temporary lull in inflation to below 5 percent in the early 1980 s was made possible only by distortionary wage and price freezes. Throughout 
the period, monetary policy faced multiple and varying objectives that were seldom clearly specified and not consistent with low inflation. In the mid-1980s, however, the government adopted the principle that all of its funding requirements would be met directly from private markets, a broad structural reform program was set in motion, and the exchange rate was floated. These policies helped bring inflation down from 17 percent to around 5 percent at the time that inflation targeting was adopted.

The institutional framework for inflation targeting includes several unusual elements. The RBA mandates "stability in the general level of prices" as the primary objective of monetary policy. Parliament chooses the objective and requires the Minister of Finance and the governor to select a specific target. The publicly announced Policy Targets Agreement (PTA) between the minister and the governor stipulates that annual changes in consumer price inflation lie between a prespecified range (subject to caveats). In the event of a breach of the target, the finance minister requests the nonexecutive directors of the Reserve Bank to make an explanation of the reasons for the breach and the actions necessary to bring inflation back within the range. While the finance minister has explicit power to remove the governor, this option has not been seriously considered even on occasions when the target has been breached.

As the inflation targeting "pioneer," New Zealand has implemented important changes in this framework over the past decade (Bernanke and others, 1999; Sherwin, 2000). First, the inflation target range was widened to $0-3$ percent in December 1996, from 0-2 percent following the election of a coalition government. The range was widened in response to the public perception that the previous range was too narrow to be credible, as well as instrument instability. Second, the parameters of the inflation target range, which were initially seen as bounded by "electric fences," have been made more flexible in recent years. Third, the policy horizon was extended from around one year initially to one and a half years in response to the greater weight assigned to the indirect as opposed to the direct impact of the exchange rate on inflation. Fourth, operating targets and indicators have evolved in response to structural changes and the changing policy transmission channels. The attention paid to real sector inflation indicators as policy guides earlier on gave way to a focus on the trade-weighted exchange rate index and interest rates because of their relatively strong relationship with inflation. Beginning in June 1997, policy was formulated in terms of a monetary conditions index band. The subsequent pickup in interest rate volatility led to the adoption of an overnight interbank cash rate operating target in March 1999, however.
New Zealand's experence with inflation targeting has been positive, notwithstanding the economy's inherent vulnerability to external shocks and the lack of international experience upon which it could draw. Inflation declined to the average rate for OECD countries, from rates above the average. In addition, spreads between New Zealand bonds and U.S. bonds have narrowed considerably. This success reflects the willingness to "learn by doing," as well as the panoply of policy changes undertaken by the national authorities.

\section{Poland}

The National Bank of Poland (NBP) announced that it would adopt inflation targeting in September 1998 , but the actual start of full-fledged inflation targeting can be marked by the widening of the exchange rate band in March 1999. Inflation targeting is viewed as the most effective way to reduce inflation and pave the way for European Union membership. Monetary targeting was not considered a workable alternative because the money multiplier and money demand remain very unstable (National Bank of Poland, 1998).

Beginning in 1995, simultaneous achievement of domestic and external stability of the currency was complicated by strong capital inflows in the context of Poland's commitment under the OECD capital code to remove all remaining capital restrictions by December 1999 (IMF, 1999a). The NBP sterilized capital inflows by selling its entire portfolio of negotiable Treasury securities and issuing NBP bills. In addition, the NBP increased the flexibility of the exchange rate. In May 1995, a crawling band was announced that followed the crawling peg that was in place since October 1991. The band was widened over time and the crawl slowed. Nevertheless, the Polish currency (zloty) experienced a cumulated real appreciation that contributed to the worsening of the current account. Also, nominal short-term interest rates remained very high and real short-term interest rates increased considerably as inflation was brought down faster than expected.

The new National Bank of Poland Act that came into effect in January 1998 defines the NBP's primary objective as price stability and provides the NBP with instrument independence. The new constitution of the Republic of Poland prohibits central bank financing of public deficits. The NBP Act also created a new policymaking body that announced at its first meeting in February 1998 a December-toDecember inflation target for 1998 of 9.5 percent or less. In September 1998, the NBP published its medium-term strategy of lowering inflation to 4 percent by 2003 (National Bank of Poland, 1998), 
coincident with Poland's preparations for accession to the European Union. The annual target was set at 8.0 to 8.5 percent for 1999 . When disinflationary pressures appeared to be stronger than expected, however, the NBP lowered the 1999 target to 6.6 to 7.8 percent in March 1999. At the same time, the NBP widened the exchange rate band to \pm 15 percent-equivalent to the exchange rate band of the Exchange Rate Mechanism (ERM) of the European Monetary System. In April 2000, Poland moved to a full float.

Poland's short experience with inflation targeting has been somewhat mixed. It is characterized by initial reductions in inflation and inflation expectations in a difficult macroeconomic environment of widening fiscal and current account deficits. During this time, the NBP lowered the 28-day NBP bill rate from 24 percent in February 1998 to 13 percent in August 1999. From March 1999, year-over-year inflation rose from 6 percent to more than 10 percent at the beginning of 2000, however, resulting mainly from rising oil and commodity prices, the depreciation of the zloty, and fiscal imbalances. In response, the NBP raised the NBP bill rate to 17.5 percent. The resulting appreciation of the zloty, which widened the current account deficit, further complicated monetary policy.

Important challenges remain with respect to Poland's inflation targeting framework (NBP, $1999 b)$. First, the process of transmitting central bank signals to the economy is still distorted due to excess liquidity and the institutional structure of the banking sector. Second, deficiencies in the availability and quality of statistical data remain that make it difficult to identify inflationary pressures on a timely basis. The NBP is addressing both of these issues. Third, the expansionary stance of fiscal policy is regarded as an impediment to a further reduction in inflation.

\section{South Africa}

South Africa is the latest country to introduce a full-fledged inflation targeting framework. After a preparatory period, the Minister of Finance announced the adoption of inflation targeting in his budget speech in February 2000 (Manuel, 2000). The new policy framework is considered a formalization of the "implicit inflation targeting" or "eclectic monetary policy approach" that the South African Reserve Bank (SARB) has followed since 1997. Even though the SARB continued to announce intermediate targets for the growth of M3 until 1999, M3 no longer served as the primary indicator for policy decisions, since its relation to inflation had weakened severely due to financial lib- eralization and huge increases in transactions in money and capital markets (Stals, 1999). Even with frequent overshooting of the intermediate target, inflation in South Africa remained on a downward trend, notwithstanding exchange rate depreciations in 1996 and 1998. The move to an explicit inflation targeting framework occurred in times of relative economic stability and was deemed advantageous in light of the lack of coordination between the SARB and the government (Mboweni, 1999a).

South Africa's government announced its first inflation target after consultations with the SARB. The target is defined as an annual average inflation rate of 3-6 percent, measured by consumer price inflation excluding mortgage costs (CPIX) to be achieved for the year 2002. A headline inflation index is considered to be the best understood and most credible index. The target range reflects the uncertainties about the inflation process and the required discretion in monetary policy. The time horizon was chosen to account for the lags between monetary policy actions and inflation, which for South Africa are estimated to lie in the range of 18 to 24 months (Mboweni, 2000). The SARB's operational procedures were left unchanged following the introduction of the inflation targeting framework. The SARB will continue to steer the overnight rate through daily repurchase agreements.

The formal adoption of inflation targeting followed a preparatory phase of about two years. During this time, the SARB made important changes in its decision-making process and communication policies to increase its transparency and accountability. The SARB partly reorganized its structure, drawing on the expertise of inflation targeting central banks and the IMF. For the formulation of monetary policy, the SARB established a Monetary Policy Committee in August 1999 consisting of the governor and the three deputy governors as voting members and senior SARB nonvoting members. After each MPC meeting, the monetary policy stance is publicly explained. With the creation of a Monetary Policy Forum that meets twice a year, the SARB has set the stage to better communicate its policy to its shareholders and "interested parties" (Mboweni, 2000). In addition, the SARB publishes a semiannual Monetary Policy Review to describe policy decisions in detail and to analyze potential effects on inflation. The SARB has also created a fully fledged Media Office that is concerned with external communication. To build the necessary expertise for inflation forecasting, the SARB restructured its Research Department, enhanced its computer capacity, and is enlisting the help of experts from other central banks to develop a small-scale model designed specifically for inflation forecasting purposes (Mboweni, 1999a,b). 


\section{Spain}

The Bank of Spain (BoS) announced in December 1994 its intention to adopt an inflation targeting framework from January 1995 and it operated under this framework until Spain entered the European Economic and Monetary Union in January 1999. The decision to target inflation came in response to the Law on the Autonomy of the BoS as required by the 1993 Maastricht Treaty on European Union. The law defines price stability as the primary objective of monetary policy, provides the BoS with instrument independence, prohibits financing of government expenditure, and specifies measures for transparency and accountability (Gutiérrez, 1998). In addition to these institutional changes, the introduction of inflation targeting was motivated by the widening of the exchange rate band of the Exchange Rate Mechanism (ERM) of the European Monetary System to \pm 15 percent in August 1993, and the weakening of the link between monetary aggregates and nominal income. Since 1984, the BoS had announced annual intermediate targets for the growth of broad money (Ayuso and Escrivá, 1998). After Spain entered the ERM in June 1989 , the monetary targets were subordinated to the exchange rate target. When the exchange rate band ceased to be the nominal anchor for monetary policy, monetary targeting was not reactivated because money demand was seen as no longer stable (Vega, 1998). Under the inflation targeting framework, broad money growth continued to play a role as the leading indicator (Gutiérrez, 1998).

The BoS specified its first inflation target as a reduction of consumer price inflation to less than 3 percent over the course of the following three years. Defining the target in terms of CPI, rather than as an underlying inflation index, was thought to enhance the simplicity and transparency of the target. For the same reasons, the BoS refrained from defining escape clauses (Gutiérrez, 1998). The announcement of the first target was timed to coincide with a value-added tax (VAT) increase that took effect on January 1, 1995, and a strengthening of the economy. Thus, unlike most other countries, Spain adopted inflation targeting at a time when the targets would immediately be put to the test (Bernanke and others, 1999). When it became apparent that the VAT pass-through was not significant, the BoS specified the transition path to the medium-term inflation target and announced a target inflation range of 3.5 to 4 percent in 1996. The targets were then reduced to 2.5 percent for 1997 and to 2 percent for 1998.

Spain's inflation targeting framework also comprised a range of accountability mechanisms and communication vehicles. The governor was held accountable for monetary policy by reporting regularly to the Parliament and appearing before Con- gress and the Senate. From March 1995, the BoS published semiannual inflation reports, which did not include any quantitative inflation forecasts, however, since their publication was regarded as of "secondary importance" and could "result in the wrong signals being sent to agents" due to the underlying uncertainty (Gutiérrez, 1998).

During its four-year period of inflation targeting, inflation in Spain fell to its lowest levels in decades. Over the first year, however, monetary policy faced several challenges. Despite the rise in central bank rates in response to inflation uncertainties, the Spanish currency (peseta) came under speculative pressure in March 1995 and was devalued (Gutiérrez, 1998). The BoS continued to tighten monetary policy until December 1995, when actual inflation reached 4.3 percent and the peseta strengthened considerably. Inflation expectations fell continuously, the peseta moved above its central parity, leading to a reduction of the repo rate, and the interest rate differential with German rates narrowed. This development was supported by a tightening of fiscal policy, undertaken to fulfill the fiscal convergence criteria of European Economic and Monetary Union (EMU) (Bernanke and others, 1999). Ultimately, Spain's consumer price inflation fell below 2 percent and long-term interest rates fell below 4 percent, qualifying Spain to become a starting member of European Economic and Monetary Union.

\section{Sweden}

The Sveriges Riksbank (central bank) announced that it would adopt an inflation targeting framework on January 15, 1993-eight weeks after it abandoned its currency peg to the European Currency Unit (ECU). Sweden let its currency (krona) float after a sustained defense in 1992 to numerous speculative attacks on the krona through high interest rates. By September 1993, the overnight interest rate had been raised to 500 percent-an interest rate level that was untenable.

Sweden's macroeconomic situation at the beginning of the 1990s was characterized by serious imbalances. Inflation averaged 10 percent, unemployment more than tripled from 1990 to 1992 , the fiscal deficit increased sharply, and the current account deficit widened. With the widespread support of the Swedish public and government, the Riksbank adopted an inflation targeting regime as part of a stabilization package that emphasized price stability. The inflation target-defined as 2 percent consumer price inflation with a degree of tolerance of \pm 1 percent-was to be achieved by the beginning of 1995 .

Sweden was one of the pioneer countries to adopt inflation targeting and the institutional features of its framework evolved over time. The two most promi- 
nent changes were associated with the transparency of monetary policy and central bank independence, both of which were initiated in 1997. The Riksbank published quantitative inflation forecasts for the first time in its inflation report in December 1997. Since June 1999, the Riksbank has indicated the uncertainty of inflation forecasts through "fan charts" for a horizon of 24 months. Based on these changes, the Riksbank distinguishes three phases of its inflation targeting regime (Berg, 1999): the establishment of inflation targeting (1993-95), the communication of explicit inflation forecasts (1996-97), and the introduction of distribution forecast targeting (since 1998). The Riksbank also announced at the beginning of 1999 that it will indicate in advance when deviations from the inflation target are justified due to transitory effects (Heikenstein, 1999).

The Riksbank gained de jure independence from political influence through the amendments to the Riksbank Act that came into force in January 1999. Under the new law, maintaining price stability is the primary objective of monetary policy, the Riksbank is free from government instructions, and the Executive Board was created as the new executive body of the central bank (Heikenstein and Vredin, 1998). Transparency and accountability of the Riksbank were further enhanced by publishing the minutes of Executive Board meetings with a lag of six to eight weeks, and the requirement to make a written report on monetary policy to the parliamentary standing committee at least twice a year.

The Swedish experience with inflation targeting can be judged a success. Credibility of monetary policy was quickly achieved, although the inflation targeting regime was not very transparent in the introductory phase. The Swedish experience shows that deeds and the support of the government rather than the institutional setting can help dampen inflation expectations. Steady fiscal consolidation after the adoption of inflation targeting also enhanced its credibility. Inflation was brought down to the target level within two years and remained low thereafter. The success of inflation targeting was supported by aggregate demand and supply shocks and temporary factors that put inflation on a downward trend. Inflation expectations average around 2 percent over the inflation targeting period. Although exchange rate variability has remained relatively high, the pass-through to consumer price inflation has weakened mainly because exchange rate movements are perceived to be temporary (Berg, 1999).

\section{United Kingdom}

In October 1992, the Chancellor of the Exchequer announced the adoption of inflation targeting as the
Bank of England's (BoE) new monetary policy framework after the United Kingdom had exited the Exchange Rate Mechanism (ERM) of the European Monetary System one month earlier. Inflation targeting was to provide a new nominal anchor and restore credibility. Monetary targeting was not viewed as a viable alternative since money demand instabilities had rendered the use of broad money and base money intermediate targets unsuccessful during the 1970 s and 1980s.

At the onset of the new policy framework, the United Kingdom's macroeconomic situation was characterized by contained inflation, weak domestic demand despite a slight rebound of the real economy after the 1990-91 recession, and stricter fiscal policy. The two-year episode of exchange rate targeting within the ERM had contributed to a reduction in inflation by more than six percentage points, to about $31 / 2$ percent in September 1992. Despite the sharp depreciation of the pound, the macroeconomic environment was therefore favorable to locking in the disinflation successes and achieving the first inflation target. However, inflation expectations, which had fallen to about $4 \frac{1}{2}$ percent prior to the depreciation, surged after the exchange rate crisis, to more than 6 percent (Haldane, 2000), indicating the need for a tight, clear, and transparent monetary policy.

The United Kingdom was at the forefront in establishing a formal inflation targeting framework. The BoE's early publication of a comprehensive inflation report and the bank's efforts to formalize its forecasting framework, including the publication of "fan charts," were innovative. The strong efforts undertaken by the BoE in the area of inflation forecasting and its means of communication and accountability are viewed to reflect the bank's limited control over instruments before gaining instrument independence in May 1997 (Bernanke and others, 1999). Instrument independence granted to the BoE's newly created Monetary Policy Committee (MPC) contributed to an immediate reduction in inflation expectations, by about 0.5 percentage point (Haldane, 2000). The Bank of England Act, which came into force in June 1998, provided the statutory basis for the changes undertaken. The Act also sets out price stability as the main objective of monetary policy and assigns the Treasury the definition of price stability (Rodgers, 1998).

The United Kingdom's inflation targeting framework is characterized by the following features. The Treasury sets inflation targets in each Budget Statement; targets are currently at 2.5 percent for retail price inflation excluding mortgage payments (RPIX). The point target is viewed as advantageous compared to the 1-4 percent target range, which was used in 1992-95 because it helps to remove any ambiguity about monetary policy, eliminates the "range 
bias" of inflation expectations, and makes transparent the symmetry of policy actions (Haldane, 2000). The BoE's communications means comprise the quarterly publication of inflation reports, including inflation forecasts for two-year horizons with uncertainty ranges ("fan charts"), the announcement of MPC's decisions immediately after the meetings, the publication of the MPC meeting minutes and votes with a two-week lag, and frequent speeches given by the MPC members to explain the BoE's monetary policy. To enhance accountability, the Governor of the MPC is required to send an open letter to the Chancellor of the Exchequer as soon as inflation deviates by one percentage point or more from the point target. The letter must explain the reasons for the target deviations, policy measures intended to be taken, and the estimated time horizon envisaged to return to the target path (Rodgers, 1998).

The United Kingdom has not experienced target breaches since the introduction of the inflation targeting framework. The general success of inflation targeting reflects the improving fiscal position. The gaining of credibility was not always smooth, however; on a number of occasions, the government and the BoE have disagreed on the monetary policy decisions to be taken, with the BoE assessing inflationary dangers higher than the government. This raised uncertainty and affected inflation expectations, which was eliminated only when the $\mathrm{BoE}$ received instrument independence. Since then, inflation expectations have been near the 2.5 percent target (Haldane, 2000). 


\section{References}

Agénor, Pierre-Richard, C. John McDermott, and Eswar S. Prasad, 1999, "Macroeconomic Fluctuations in Developing Countries: Some Stylized Facts," IMF Working Paper 99/35 (Washington: International Monetary Fund).

Akerlof, George A., William T. Dickens, and George L. Perry, 1996, "The Macroeconomics of Low Inflation," Brookings Papers on Economic Activity: 1, Brookings Institution.

Alexander, William E., Tomás J. T. Baliño, Charles Enoch, Francesco Caramazza, George Iden, David Marston, Johannes Mueller, Ceyla Pazarbasioglu, Marc Quintyn, Matthew Saal, and Gabriel Sensenbrenner, 1995, The Adoption of Indirect Instruments of Monetary Policy, IMF Occasional Paper No. 126 (Washington: International Monetary Fund).

Allen, William A., 1999, "Inflation Targeting: The British Experience," Bank of England Handbooks in Central Banking Lecture Series No. 1 (London: Bank of England).

Andrés, Javier, Ricardo Mestre, and Javier Vallés, 1998, "A Structural Model for the Analysis of the Monetary Policy Transmission Mechanism," in Monetary Policy and Inflation in Spain, ed. by José Luis Malo de Molina, José Viñals, and Fernando Gutiérrez (New York: St. Martin's Press).

Armour, Jamie, and Agathe Côté, 2000, "Feedback Rules for Inflation Control: An Overview of Recent Literature," Bank of Canada Review (Winter 1999-2000), pp. 43-54.

Aninat, Eduardo, 2000, "Closing Remarks," paper presented at the High-Level Seminar at the IMF: Implementing Inflation Targets, Washington, March. Available via the Internet: http://www.imf.org/external/ pubs/ft/seminar/2000/targets/index.htm

Archer, David, 2000, "Inflation Targeting in New Zealand," paper presented at the High-Level Seminar at the IMF: Implementing Inflation Targets, Washington, March. Availble via the Internet: http://www.imf.org/external/pubs/ft/seminar/2000/ targets/index.htm

Ayuso, Juan, and José Luis Escrivá, 1998, "Trends in the Monetary Policy Strategy in Spain," in Monetary Policy and Inflation in Spain, ed. by José Luis Malo de Molina, José Viñals, and Fernando Gutiérrez (New York: St. Martin's Press).

Aziz, Jahangir, Francesco Caramazza, and Ranil Salgado, 2000, "Currency Crises-In Search of Common Elements," IMF Working Paper 2000/67 (Washington: International Monetary Fund).
Ball, Laurence, 1999, "Policy Rules for Open Economies," in Monetary Policy Rules, ed. by John B. Taylor (Chicago: University of Chicago Press).

Banco Central do Brasil Monetary Policy Committee, 1999, Inflation Report (Brasilia, December).

Banco Central do Brasil, 2000, Inflation Report. Available via the Internet: http://www.bcb.gov.br/ingles/relinf/ frmdef.asp

Bank for International Settlements, 1999, Annual Report (Basel).

Bank of Canada, 1999, Monetary Policy Report (Ottawa, November).

Bank of England, 1997, Quarterly Bulletin (London, August).

, 1999, Inflation Report (London, November).

Bank of Israel, 1999, Inflation Report (Tel Aviv, JanuaryJune).

-, 2000, Recent Economic Developments, No. 89 (Tel Aviv, January).

Battellino, Ric, John Broadbent, and Philip Lowe, 1997, "The Implementation of Monetary Policy in Australia," Reserve Bank of Australia Research Discussion Paper No. 9703 (Sydney: Reserve Bank of Australia),

Beck, Thorsten, Asli Demirgüç-Kunt, and Ross Levine, 1999, “A New Database on Financial Development and Structure," World Bank Policy Research Working Paper No. 2146 (Washington: World Bank).

Berg, Claes, 1999, "Inflation Forecast Targeting: The Swedish Experience," Sveriges Riksbank Quarterly Review, Vol. 3, pp. 44-70.

Bernanke, Ben S., Thomas Laubach, Frederic S. Mishkin, and Adam S. Posen, 1999, Inflation Targeting: Lessons from the International Experience (Princeton: Princeton University Press).

Bertocchi, Graziella, and Michael Spagat, 1993, "Learning, Experimentation, and Monetary Policy," Journal of Monetary Economics, Vol. 32 (August), pp. 169-83.

Blejer, Mario I., Alain Ize, Alfredo M. Leone, and Sergio Werlang, eds., 2000, Inflation Targeting in Practice: Strategic and Operational Issues and Application to Emerging Market Economies (Washington: International Monetary Fund).

Blejer, Mario I., Alfredo M. Leone, Pau Rabanal, and Gerd Schwartz, July 2000, "Inflation Targeting in the Context of IMF-Supported Adjustment Programs" (unpublished; Washington: International Monetary Fund).

Blinder, Alan S., 1998, Central Banking in Theory and Practice (Cambridge, Massachusetts: MIT Press). 
Bogdanski, Joel, Alexandre A. Tombini, and Sérgio Ribeiro da Costa Werlang, 2000, "Implementing Inflation Targeting in Brazil." Available via the Internet: http://www.bcb.gov.br/ingles/public/wps/default.shtm

Borio, Claudio E.V., 1997, "The Implementation of Monetary Policy in Industrial Countries: A Survey," Bank for International Settlements Economics Paper No. 47 (July).

Brainard, William, 1967, "Uncertainty and the Effectiveness of Policy," American Economic Review, Vol. 57, pp. 411-25.

Brash, Donald T., 2000, "Inflation Targeting in New Zealand, 1988-2000," paper presented at the TransTasman Business Council, Melbourne, Australia, February. Available via the Internet: http://www,rbnz. govt.nz/speeches/index.html

Calvo, Guillermo, and Carlos A. Végh, 1999, "Inflation Stabilization and BOP Crises in Developing Countries," NBER Working Paper No. 6925 (Cambridge, Massachusetts: National Bureau of Economic Research).

Caprio, Gérard, Jr., and Daniela Klingebiel, 1996, "Bank Insolvencies: Cross-Country Experience," World Bank Policy Research Working Paper No. 1620 (Washington: World Bank).

Carstens, Agustin G., and Alejandro G. Werner, 2000, "Mexico's Monetary Policy Framework Under a Floating Exchange Rate Regime," paper presented at the High-Level Seminar at the IMF: Implementing Inflation Targets, Washington, March. Available via the Internet: http://www.imf.org/external/pubs/ft/ seminar/2000/targets/index.htm

Christoffersen, Peter F., and Robert F. Wescott, 1999, "Is Poland Ready for Inflation Targeting?" IMF Working Paper 99/41 (Washington: International Monetary Fund).

Clifton, Eric V., 1999, "Inflation Targeting: What Is the Meaning of the Bottom of the Band?" IMF Policy Discussion Paper 99/8 (Washington: International Monetary Fund).

Clinton, Kevin, 2000, "Strategic Choices for Inflation Targeting in the Czech Republic," in Inflation Targeting in Transition Economies: The Case of the Czech Republic, ed. by Warren Coats (Washington: International Monetary Fund).

— duct of Canadian Monetary Policy in the 1990s: Dealing with Uncertainty in Financial Markets," Bank of Canada Technical Report No. 80 (Ottawa: Bank of Canada).

Coats, Warren, ed., 2000, Inflation Targeting in Transition Economies: The Case of the Czech Republic (Washington: International Monetary Fund).

Corbo, Vittorio, 1999, "Monetary Policy in Latin America in the 90s," paper presented at the Third Annual Conference of the Central Bank of Chile, Santiago, Chile, September.

Czech National Bank, 1999a, CNB Monetary Strategy, Document Approved by the Board of the CNB. Available via the Internet: http://www.cnb.cz/en/ _mpolitika/dms.htm

, 1999b, Inflation Report (October).

, 1999c, Inflation Targeting in the Czech Republic

(December), http://www.cnb.cz/en/index.html
, 2000, Monetary Policy in the Czech Republic. Available via the Internet: http://www.cnb.cz/en/ mpolitika/mon_policy-instr.htm

Debelle, Guy, 1997, "Inflation Targeting in Practice," IMF Working Paper 97/35 (Washington: International Monetary Fund).

_ and Stanley Fischer, 1994, "How Independent Should a Central Bank Be?" in Goals, Guidelines, and Constraints Facing Monetary Policymakers, ed. by Jeffrey C. Fuhrer, Federal Reserve Bank of Boston Conference Series No. 38 (U.S. Federal Reserve).

Debelle, Guy, and Glenn Stevens, 1995, "Monetary Policy Goals for Inflation in Australia," Reserve Bank of Australia Research Discussion Paper No. 9503 (Sydney: Reserve Bank of Australia).

De Fiore, Fiorella, 1998, "The Transmission of Monetary Policy in Israel," IMF Working Paper 98/114 (Washington: International Monetary Fund).

Drew, Aaron, and Ben Hunt, 1998, "The Forecasting and Policy System: Preparing Economic Projections," Reserve Bank of New Zealand Discussion Paper No. G98/7 (Wellington: Reserve Bank of New Zealand).

Edey, Malcolm, 1997, "The Debate on Alternatives for Monetary Policy in Australia," in Monetary Policy and Inflation Targeting, Proceedings of a Conference, ed. by Philip Lowe (Sydney: Reserve Bank of Australia).

Fajgenbaum, José, Michael Nowak, Trevor Alleyne, Arvind Subramanian, Gunnar Jonsson and Michael Sarel, 2000, "South Africa: Selected Issues," IMF Staff Country Report No. 00/42 (Washington: International Monetary Fund).

Fillion, Jean François, and André Léonard, 1997, "La Courbe de Phillips au Canada: Un Examen de Quelques Hypotheses," Bank of Canada Working Paper No. 97-3 (Ottawa: Bank of Canada).

Fischer, Stanley, 1994, "Modern Central Banking," paper presented at the Bank of England's Tercentenary Celebration, London, June.

_ 1995, "Central Bank Independence Revisited," American Economic Review, Papers and Proceedings, Vol. 85, pp. 201-06.

Fortin, Pierre, 1996, "The Great Canadian Slump," Canadian Journal of Economics, Vol. 29, No. 4, pp. 761-787.

Fraga, Arminio, 2000, "Monetary Policy During the Transition to a Floating Exchange Rate: Brazil's Recent Experience," Finance \& Development, Vol. 37 (March), pp. 16-18.

Freedman, Charles, 1994, "The Use of Indicators and of the Monetary Conditions Index in Canada," in Frameworks for Monetary Stability: Policy Issues and Country Experiences, ed. by Tomás J. T. Baliño and Carlo Cottarelli (Washington: International Monetary Fund).

, 2000, "Inflation Targeting in Canada," paper presented at the High-Level Seminar at the IMF: Implementing Inflation Targets, Washington, March. Available via the Internet: http://www.imf.org/external/ pubs/ft/seminar/2000/targets/index.htm

Fry, Maxwell, DeAnne Julius, Lavan Mahadeva, Sandra Roger, and Gabriel Sterne, 2000, "Key Issues in the Choice of Monetary Policy Framework," in Monetary 
Frameworks in a Global Context, ed. by Lavan Mahadeva and Gabriel Sterne (London: Routledge).

Gutiérrez, Fernando, 1998, "Monetary Policy Following the Law on the Autonomy of the Banco de España," in Monetary Policy and Inflation in Spain, ed. by José Luis Malo de Molina, José Viñals, and Fernando Gutiérrez (New York: St. Martin's Press).

Haldane, Andrew, 2000, "Targeting Inflation: The U.K. in Retrospect," in Inflation Targeting in Practice: Strategic and Operational Issues and Application to Emerging Market Economies, ed. by Mario I. Blejer, Alain Ize, Alfredo M. Leone, and Sergio Werlang (Washington: International Monetary Fund).

Haldane, Andrew, ed., 1995, Targeting Inflation: A Conference of Central Banks on the Use of Inflation Targets Organized by the Bank of England 9-10 March 1995 (London: Bank of England).

Heikensten, Lars, 1999, "The Riksbank's Inflation Target-Clarification and Evaluation," Sveriges Riksbank Quarterly Bulletin, Vol. 1, pp. 5-17.

${ }$, and Anders Vredin, 1998, "Inflation Targeting and Swedish Monetary Policy: Experience and Problems," Sveriges Riksbank Quarterly Review, Vol. 4, pp. 5-33.

Hunt, Ben, 1999, "Inter-Forecast Monetary Policy Implementation: Fixed-Instrument Versus MCI-Based Strategies," Reserve Bank of New Zealand Discussion Paper No. G99/1 (Wellington: Reserve Bank of New Zealand).

International Monetary Fund, 1998a, Chile-Selected Issues, IMF Staff Country Report No. 98/26 (Washington).

- 1998b, Czech Republic-Selected Issues, IMF Staff Country Report No. 98/36 (Washington).

- 1998c, World Economic Outlook, May 1998: A Survey by the Staff of the International Monetary Fund, World Economic and Financial Surveys (Washington).

-1999 a, Republic of Poland-Staff Report for the 1998 Article IV Consultation, IMF SM/00/36. February 17 (Washington).

-, 1999b, Monetary and Exchange Affairs Department, Country Experiences with the Use and Liberalization of Capital Controls, IMF SM/99/214, Revision 1, including supplements (Washington).

, 2000, Monetary and Exchange Affairs Department, "Supporting Document to the Code of Good Practices on Transparency in Monetary and Financial Policies" (Washington). Available via the Internet: http://www. imf.org/external/np/mae/mft/sup/index.htm

Isard, Peter, and Douglas Laxton, 2000a, "Inflation-Forecast Targeting and the Role of Macroeconomic Models," in Inflation Targeting in Transition Economies: The Case of the Czech Republic, ed. by Warren Coats (Washington: International Monetary Fund).

_ 2000b, "Issues Related to Inflation Targeting and the Bank of England's Framework," in United Kingdom-Selected Issues, IMF Staff Country Report No. 99/44 (Washington: International Monetary Fund).

, and Ann-Charlotte Eliasson, 2000, "Simple Monetary Policy Rules under Model Uncertainty," in International Finance and Financial Crises: Essays in Honor of Robert P. Flood, Jr, ed. by Peter Isard,
Assaf Razin, and Andrew K. Rose (Boston: Kluwer Academic; Washington: International Monetary Fund).

Johnson, David, 1998, "The Credibility of Monetary Policy: International Evidence Based on Surveys of Expected Inflation," in Price Stability, Inflation Targets, and Monetary Policy: Proceedings of a Conference Held by the Bank of Canada, May 1997 (Ottawa: Bank of Canada).

Jonsson, Gunnar, 1999, "Relative Merits and Implications of Inflation Targeting for South Africa," IMF Working Paper No. 99/116 (Washington: International Monetary Fund).

Kent, C., and Philip Lowe, 1998, "Property Price Cycles and Monetary Policy," in The Role of Asset Prices in the Formulation of Monetary Policy, Bank for International Settlements Conference Paper No. 5 (Basel: BIS).

King, Mervyn, 1997, "The Inflation Target Five Years On," Bank of England Quarterly Bulletin, Vol. 37 (April), pp. 434-42.

Kouparitsas, Michael A., 1996, "North-South Business Cycles," Federal Reserve Bank of Chicago Working Paper No. 96-9 (U.S. Federal Reserve).

Kumhoff, Michael, 2000, "Inflation Targeting Under Imperfect Credibility" (unpublished; Stanford: Stanford University).

Landerretche, Oscar, Felipe Morandé, and Klaus SchmidtHebbel, 1999, "Inflation Targets and Stabilization in Chile," Central Bank of Chile Working Paper No. 55 (Santiago: Central Bank of Chile).

Lane, Timothy D., Atish Ghosh, Javier Hamann, Steven Phillips, Marianne Schulze-Ghattas, and Tsidi Tsikata., 1999, IMF-Supported Programs in Indonesia, Korea and Thailand: A Preliminary Assessment, IMF Occasional Paper No. 178 (Washington: International Monetary Fund).

Leiderman, Leonardo, and Hadas Bar-Or, 2000, "Monetary Policy Rules and Transmission Mechanisms Under Inflation Targeting in Israel" (unpublished; Jerusalem, Research Department Bank of Israel).

Leiderman, Leonardo, and Gil Bufman, 2000, "Inflation Targeting Under a Crawling Band Exchange Rate Regime: Lessons from Israel," in Inflation Targeting in Practice: Strategic and Operational Issues and Application to Emerging Market Economies, ed. by Mario I. Blejer, Alain Ize, Alfredo M. Leone, and Sergio Werlang (Washington: International Monetary Fund).

Leiderman, Leonardo, and Lars E.O. Svensson, eds., 1995, Inflation Targets (London: Centre for Economic Policy Research).

Leone, Alfredo M., 1999, "Inflation Targeting in the Brazilian Setting," in Brazil-Selected Issues and Statistical Appendix, IMF Country Staff Report No. 99/97 (Washington; International Monetary Fund).

Lowe, Philip, 1997, "Monetary Policy and Inflation Targeting," in Reserve Bank of Australia Bulletin, October, pp. 14-19.

Manuel, Trevor A., 2000, "Budget Speech 2000 by Trevor A. Manuel, Minister of Finance" (February 23, 2000). Available via the Internet: http://www.gov.za

Masson, Paul R., Miguel A. Savastano, and Sunil Sharma, 1997, "The Scope for Inflation Targeting in Develop- 
ing Countries," IMF Working Paper 97/130 (Washington: International Monetary Fund).

Mboweni, Tito T., 1999a, "Abridged Actual Address by Mr. Tito T. Mboweni, Governor of the South African Reserve Bank, at the Seventy-Ninth Ordinary General Meeting of Shareholders of the Bank, 24 August 1999." Available via the Internet: http://www. resbank.co.za/Address/annual/abridged.html

-, 1999b, "Inflation Targeting in South Africa," address presented by T.T. Mboweni, Governor of the South African Reserve Bank, at the biennial Congress of the Economic Society of South Africa, Pretoria, September. Available via the Internet: http://www. resbank.co.za/Address/1999/ad060999.htm

— , 2000, "A New Monetary Policy Framework," statement issued by Mr. T.T. Mboweni, Governor of the South African Reserve Bank, as an Appendix to the "Statement of the Monetary Policy Committee -6 April 2000." Available via the Internet: http://www. resbank.co.za/Media/2000/st06042000.html

Menon, Jayant, 1995, "Exchange Rate Pass-Through," Journal of Economic Surveys, Vol. 9 (June), pp. 197-231.

Mishkin, Frederic S., 2000, "Inflation Targeting in Emerging Market Countries," NBER Working Paper No. 7618 (Cambridge, Massachusetts: National Bureau of Economic Research).

Morandé, Felipe, and Klaus Schmidt-Hebbel, 2000, "Monetary Policy and Inflation Targeting in Chile," in Inflation Targeting in Practice: Strategic and Operational Issues and Application to Emerging Market Economies, ed. by Mario I. Blejer, Alain Ize, Alfredo M. Leone, and Sergio Werlang (Washington: International Monetary Fund).

Murray, John, Mark Zelmer, and Zahir Antia, 2000, "International Financial Crises \& Flexible Exchange Rates: Some Lessons from Canada," Bank of Canada Technical Report No. 88 (Ottawa: Bank of Canada).

Mussa, Michael, and Miguel A. Savastano, 1999,"The IMF Approach to Economic Stabilization," IMF Working Paper 99/104 (Washington: International Monetary Fund).

National Bank of Poland, 1998, Medium-Term Strategy of Monetary Policy, 1999-2003 (Warsaw).

National Bank of Poland, 1999a, Monetary Policy Council, Inflation Report (III Quarter) (Warsaw).

, 1999b, Inflation Report 1998 (Warsaw).

, 1999c, Inflation Report 1999, I-II Quarter (Warsaw).

Offenbacher, Akiva, 1996, "How Inflation Has Come Down," Central Banking, Vol. VII (March), pp. 61-66.

Orphanides, Athanasios, 1998, "Monetary Policy Rules Based on Real-Time Data," Finance and Economics Discussion Series No. 1998-03 (Washington: Board of Governors of the Federal Reserve System).

Pikkarainen, Pentti, 1996, "Some Perspectives on the Principles of Monetary Policy with a Floating Markka," Bank of Finland Bulletin, Vol. 70 (August), pp. 3-6. , and Timo Tyväinen, 1993, "The Bank of Finland's Inflation Target and the Outlook for Inflation Over the Next Few Years," Bank of Finland Bulletin, Vol. 67, No. 6-7 (June-July), pp. 6-7.
Price, Robert, 1997, "The Rationale and Design of Inflation-Indexed Bonds," IMF Working Paper 97/12 (Washington: International Monetary Fund).

Reserve Bank of Australia, 1994, "Measuring 'Underlying' Inflation," Reserve Bank of Australia Bulletin (August), pp. 1-6.

_, 1996, "Statement on the Conduct of Monetary Policy by the Treasurer and the Governor (designate) of the Reserve Bank," issued August 14. Available via the Internet: http://www.rba.gov.au/about/ ab_scmp.html

_, 1999, "Semi-Annual Monetary Policy Statement" in Reserve Bank of Australia Quarterly Bulletin (November), pp. $1-45$.

Reserve Bank of New Zealand, 1999, Monetary Policy Statement (December). Available via the Internet: http://www.rbnz.govt.nz/monpol/statements/0094172. html

Rodgers, Peter, 1998, "The Bank of England Act," Bank of England Quarterly Bulletin, Vol. 38 (May), pp. 93-99.

Roger, Scott, 1998, "Core Inflation: Concepts, Uses and Measurement," Reserve Bank of New Zealand Discussion Paper No. G98/9:1-41 (Wellington: Reserve Bank of New Zealand).

Schadler, Susan, Adam Bennett, Maria Carkovic, Louis Dicks-Mireaux, Mauro Mecagni, James H. J. Morsink, and Miguel A. Savastano, 1995, IMF Conditionality: Experiences Under Stand-By and Extended Arrangements, IMF Occasional Paper No. 128 (Washington: International Monetary Fund).

Sherwin, Murray, 2000, "Strategic Choices in Inflation Targeting: The New Zealand Experience," in Inflation Targeting in Practice: Strategic and Operational Issues and Application to Emerging Market Economies, ed. by Mario I. Blejer, Alain Ize, Alfredo $\mathrm{M}$. Leone, and Sergio Werlang (Washington: International Monetary Fund).

Söderlind, Paul, and Lars E. O. Svensson, 1997, "New Techniques to Extract Market Expectations from Financial Instruments," NBER Working Paper No. 5877 (Cambridge, Massachusetts: National Bureau of Economic Research).

Stals, Chris, 1999, "Inflation Targeting as an Anchor for Monetary Policy in South Africa," address by the Governor of the South African Reserve Bank at a Breakfast Meeting of the Johannesburg Branch of the Institute of Bankers in South Africa, March 17, 1999. Available via the Internet: http://www.resbank.co.za/Address/ 1999/ad170399.html

Stone, Mark R., 2000, "The Corporate Sector Dynamics of Systemic Financial Crises," IMF Working Paper 00/114 (Washington: International Monetary Fund).

Summers, Lawrence, 1991, "Panel Discussion: Price Stability; How Should Long-Term Monetary Policy Be Determined?" Journal of Money, Credit and Banking, Vol. 23 (August), pp. 625-31.

Svensson, Lars E.O., 1997, "Inflation Forecast Targeting: Implementing and Monitoring Inflation Targets," European Economic Review, Vol. 41 (June), pp. 1111-46.

1998, "Open-Economy Inflation Targeting," NBER Working Paper No. 6545 (Cambridge, Massachusetts: National Bureau of Economic Research). 
Sveriges Riksbank, 1999, Inflation Report (Stockholm), Taylor, John B., ed., 1999, Monetary Policy Rules (Chicago: University of Chicago Press).

Thiessen, Gordon G., 1998, "The Canadian Experience with Targets for Inflation Control," Gibson Lecture at Queen's University, Kingston, Ontario, Canada, October.

Tyrväinen, Timo, 1997, "Have the Dynamics of Finnish Inflation Changed?" Bank of Finland Bulletin, Vol. 71 (August), pp. 3-7.

Ugolini, Piero, 1996, "Crawling Exchange Rate Bands Under Moderate Inflation," MAE Operational Paper No. 96/4 (Washington: International Monetary Fund).

Van't dack, Joseph, 1999, "Monetary Policy Operating Procedures in Emerging Market Economies," Bank for International Settlements Policy Paper No. 5 (Basel: BIS).
Vega, Juan Luis, 1998, "The ALP Long-Run Demand Function," in Monetary Policy and Inflation in Spain, ed. by José Luis Malo de Molina, José Viñals, and Fernando Gutiérrez (NewYork: St. Martin's Press).

Walsh, Carl E., 1995, "Optimal Contracts for Central Bankers," American Economic Review, Vol. 85 (March), pp. 150-67.

Werlang, Sérgio, 2000, "Issues in the Adoption of an Inflation Targeting Framework in Brazil," paper presented at the High-Level Seminar at the IMF: Implementing Inflation Targets, Washington, March. Available via the Internet: http://www.imf.org/external/pubs/ft/ seminar/2000/targets/index.htm

Zelmer, Mark, 1996, "Strategy versus Tactics," in Money Markets and Central Bank Operations: Proceedings of a Conference, Bank of Canada, November 1995 (Ottawa: Bank of Canada). 


\section{Recent Occasional Papers of the International Monetary Fund}

202. Adopting Inflation Targeting: Practical Issues for Emerging Market Countries, by Andrea Schaechter, Mark R. Stone, and Mark Zelmer. 2000.

201. Developments and Challenges in the Caribbean Region, by Samuel Itam, Simon Cueva, Erik Lundback, Janet Stotsky, and Stephen Tokarick. 2000.

200. Pension Reform in the Baltics: Issues and Prospects, by Jerald Schiff, Niko Hobdari, Axel Schimmelpfennig, and Roman Zytek. 2000.

199. Ghana: Economic Development in a Democratic Environment, by Sérgio Pereira Leite, Anthony Pellechio, Luisa Zanforlin, Girma Begashaw, Stefania Fabrizio, and Joachim Harnack. 2000.

198. Setting Up Treasuries in the Baltics, Russia, and Other Countries of the Former Soviet Union: An Assessment of IMF Technical Assistance, by Barry H. Potter and Jack Diamond. 2000.

197. Deposit Insurance: Actual and Good Practices, by Gillian G.H. Garcia. 2000.

196. Trade and Trade Policies in Eastern and Southern Africa, by a staff team led by Arvind Subramanian, with Enrique Gelbard, Richard Harmsen, Katrin Elborgh-Woytek, and Piroska Nagy. 2000.

195. The Eastern Caribbean Currency Union-Institutions, Performance, and Policy Issues, by Frits van Beek, José Roberto Rosales, Mayra Zermeño, Ruby Randall, and Jorge Shepherd. 2000.

194. Fiscal and Macroeconomic Impact of Privatization, by Jeffrey Davis, Rolando Ossowski, Thomas Richardson, and Steven Barnett. 2000.

193. Exchange Rate Regimes in an Increasingly Integrated World Economy, by Michael Mussa, Paul Masson, Alexander Swoboda, Esteban Jadresic, Paolo Mauro, and Andy Berg. 2000.

192. Macroprudential Indicators of Financial System Soundness, by a staff team led by Owen Evans, Alfredo M. Leone, Mahinder Gill, and Paul Hilbers. 2000.

191. Social Issues in IMF-Supported Programs, by Sanjeev Gupta, Louis Dicks-Mireaux, Ritha Khemani, Calvin McDonald, and Marijn Verhoeven. 2000.

190. Capital Controls: Country Experiences with Their Use and Liberalization, by Akira Ariyoshi, Karl Habermeier, Bernard Laurens, Inci Ötker-Robe, Jorge Iván Canales Kriljenko, and Andrei Kirilenko. 2000.

189. Current Account and External Sustainability in the Baltics, Russia, and Other Countries of the Former Soviet Union, by Donal McGettigan. 2000.

188. Financial Sector Crisis and Restructuring: Lessons from Asia, by Carl-Johan Lindgren, Tomás J.T. Baliño, Charles Enoch, Anne-Marie Gulde, Marc Quintyn, and Leslie Teo. 1999.

187. Philippines: Toward Sustainable and Rapid Growth, Recent Developments and the Agenda Ahead, by Markus Rodlauer, Prakash Loungani, Vivek Arora, Charalambos Christofides, Enrique G. De la Piedra, Piyabha Kongsamut, Kristina Kostial, Victoria Summers, and Athanasios Vamvakidis. 2000.

186. Anticipating Balance of Payments Crises: The Role of Early Warning Systems, by Andrew Berg, Eduardo Borensztein, Gian Maria Milesi-Ferretti, and Catherine Pattillo. 1999.

185. Oman Beyond the Oil Horizon: Policies Toward Sustainable Growth, edited by Ahsan Mansur and Volker Treichel. 1999.

184. Growth Experience in Transition Countries, 1990-98, by Oleh Havrylyshyn, Thomas Wolf, Julian Berengaut, Marta Castello-Branco, Ron van Rooden, and Valerie Mercer-Blackman. 1999.

183. Economic Reforms in Kazakhstan, Kyrgyz Republic, Tajikistan, Turkmenistan, and Uzbekistan, by Emine Gürgen, Harry Snoek, Jon Craig, Jimmy McHugh, Ivailo Izvorski, and Ron van Rooden. 1999.

182. Tax Reform in the Baltics, Russia, and Other Countries of the Former Soviet Union, by a staff team led by Liam Ebrill and Oleh Havrylyshyn. 1999.

181. The Netherlands: Transforming a Market Economy, by C. Maxwell Watson, Bas B. Bakker, Jan Kees Martijn, and Ioannis Halikias. 1999.

180. Revenue Implications of Trade Liberalization, by Liam Ebrill, Janet Stotsky, and Reint Gropp. 1999.

179. Dinsinflation in Transition: 1993-97, by Carlo Cottarelli and Peter Doyle. 1999.

178. IMF-Supported Programs in Indonesia, Korea, and Thailand: A Preliminary Assessment, by Timothy Lane, Atish Ghosh, Javier Hamann, Steven Phillips, Marianne Schulze-Ghattas, and Tsidi Tsikata. 1999. 
177. Perspectives on Regional Unemployment in Europe, by Paolo Mauro, Eswar Prasad, and Antonio Spilimbergo. 1999.

176. Back to the Future: Postwar Reconstruction and Stabilization in Lebanon, edited by Sena Eken and Thomas Helbling. 1999.

175. Macroeconomic Developments in the Baltics, Russia, and Other Countries of the Former Soviet Union, 1992-97, by Luis M. Valdivieso. 1998.

174. Impact of EMU on Selected Non-European Union Countries, by R. Feldman, K. Nashashibi, R. Nord, P. Allum, D. Desruelle, K. Enders, R. Kahn, and H. Temprano-Arroyo. 1998.

173. The Baltic Countries: From Economic Stabilization to EU Accession, by Julian Berengaut, Augusto Lopez-Claros, Françoise Le Gall, Dennis Jones, Richard Stern, Ann-Margret Westin, Effie Psalida, Pietro Garibaldi. 1998.

172. Capital Account Liberalization: Theoretical and Practical Aspects, by a staff team led by Barry Eichengreen and Michael Mussa, with Giovanni Dell'Ariccia, Enrica Detragiache, Gian Maria Milesi-Ferretti, and Andrew Tweedie. 1998.

171. Monetary Policy in Dollarized Economies, by Tomás Baliño, Adam Bennett, and Eduardo Borensztein. 1998.

170. The West African Economic and Monetary Union: Recent Developments and Policy Issues, by a staff team led by Ernesto Hernández-Catá and comprising Christian A. François, Paul Masson, Pascal Bouvier, Patrick Peroz, Dominique Desruelle, and Athanasios Vamvakidis. 1998.

169. Financial Sector Development in Sub-Saharan African Countries, by Hassanali Mehran, Piero Ugolini, Jean Phillipe Briffaux, George Iden, Tonny Lybek, Stephen Swaray, and Peter Hayward. 1998.

168. Exit Strategies: Policy Options for Countries Seeking Greater Exchange Rate Flexibility, by a staff team led by Barry Eichengreen and Paul Masson with Hugh Bredenkamp, Barry Johnston, Javier Hamann, Esteban Jadresic, and Inci Ötker. 1998.

167. Exchange Rate Assessment: Extensions of the Macroeconomic Balance Approach, edited by Peter Isard and Hamid Faruqee. 1998

166. Hedge Funds and Financial Market Dynamics, by a staff team led by Barry Eichengreen and Donald Mathieson with Bankim Chadha, Anne Jansen, Laura Kodres, and Sunil Sharma. 1998.

165. Algeria: Stabilization and Transition to the Market, by Karim Nashashibi, Patricia Alonso-Gamo, Stefania Bazzoni, Alain Féler, Nicole Laframboise, and Sebastian Paris Horvitz. 1998.

164. MULTIMOD Mark III: The Core Dynamic and Steady-State Model, by Douglas Laxton, Peter Isard, Hamid Faruqee, Eswar Prasad, and Bart Turtelboom. 1998.

163. Egypt: Beyond Stabilization, Toward a Dynamic Market Economy, by a staff team led by Howard Handy. 1998.

162. Fiscal Policy Rules, by George Kopits and Steven Symansky. 1998.

161. The Nordic Banking Crises: Pitfalls in Financial Liberalization? by Burkhard Drees and Ceyla Pazarbaş10ğlu. 1998.

160. Fiscal Reform in Low-Income Countries: Experience Under IMF-Supported Programs, by a staff team led by George T. Abed and comprising Liam Ebrill, Sanjeev Gupta, Benedict Clements, Ronald McMorran, Anthony Pellechio, Jerald Schiff, and Marijn Verhoeven. 1998.

159. Hungary: Economic Policies for Sustainable Growth, Carlo Cottarelli, Thomas Krueger, Reza Moghadam, Perry Perone, Edgardo Ruggiero, and Rachel van Elkan. 1998.

158. Transparency in Government Operations, by George Kopits and Jon Craig. 1998.

157. Central Bank Reforms in the Baltics, Russia, and the Other Countries of the Former Soviet Union, by a staff team led by Malcolm Knight and comprising Susana Almuiña, John Dalton, Inci Otker, Ceyla Pazarbaşığlu, Arne B. Petersen, Peter Quirk, Nicholas M. Roberts, Gabriel Sensenbrenner, and Jan Willem van der Vossen. 1997.

Note: For information on the title and availability of Occasional Papers not listed, please consult the IMF Publications Catalog or contact IMF Publication Services. 